\title{
THE DEBT-CONTRACTING VALUE OF
}

\section{ACCOUNTING NUMBERS, RENEGOTIATION, AND INVESTMENT EFFICIENCY}

\author{
by \\ Yiwei Dou \\ A thesis submitted in conformity with the requirements \\ for the degree of Doctor of Philosophy \\ Joseph L. Rotman School of Management University of Toronto \\ May 2012
}

(C) Copyright by Yiwei Dou (2012) 


\title{
THE DEBT-CONTRACTING VALUE OF ACCOUNTING NUMBERS, RENEGOTIATION, AND INVESTMENT EFFICIENCY
}

\author{
Yiwei Dou \\ A thesis submitted in conformity with the requirements \\ for the degree of Doctor of Philosophy \\ Joseph L. Rotman School of Management University of Toronto
}

May 2012

\begin{abstract}
This study investigates the impact of the debt-contracting value (DCV) of borrowers' accounting information on the likelihood of private debt renegotiation and the implication of renegotiation for borrowing firms' investment efficiency. Accounting numbers, as contractible signals, are broadly used in formal debt contracting. DCV captures the inherent ability of firms' accounting numbers to predict future credit quality. Building on incomplete contract theory, I hypothesize that a lower DCV of a borrower's accounting numbers creates ex post incentives for both parties to renegotiate the terms of the initial contract, leading to a higher probability of renegotiation. During the renegotiation, the lenders can extract partial gains from the borrowers' investment according to their relative bargaining power. Anticipating the high-probability of renegotiation reduces the ex ante investment incentives of borrowers, inducing underinvestment. Using a sample of 3,720 private debt contracts, I find that $76 \%$ of the contracts are renegotiated before maturity, and $75 \%$ of renegotiation cases are related to the changes of accounting-based contractual terms. I further find that firms with a higher DCV have a lower probability
\end{abstract}


of renegotiation and less underinvestment. Moreover, the impact of DCV on investment increases with lenders' relative bargaining power. 


\section{Acknowledgements}

I am grateful to my supervisors, Jeffrey Callen and Franco Wong, for their continuous guidance and support throughout my time at Rotman, and the other members of my dissertation committee, Jan Mahrt-Smith and Gordon Richardson, for their excellent comments and suggestions. I owe my special gratitude to Ole-Kristian Hope, Hai Lu, Baohua Xin, and Feng Chen for advice and support during my doctoral studies. I am also very thankful to Alex Edward, Gus De Franco, Yu Hou, Alastair Lawrence, Heather Li, Scott Liao, Matt Lyle, Partha Mohanram, Kevin Veenstra for their help and encouragement throughout. I am indebted to Amir Sufi for sharing his debt contracting data, Andy Leone for assistance with Perl programming, and Ningzhong Li for sharing data on accounting adjustments in initial debt contracts. I dedicate this dissertation to my wife and parents, as I could not have gotten to this stage without their love and support. 


\section{Contents}

Abstract $\quad$ ii

Acknowledgements $\quad$ iv

$\begin{array}{lll}\text { Contents } & \text { v }\end{array}$

List of Tables vii

List of Figures viii

1 Introduction $\quad 1$

2 Background and Hypotheses Development $\quad 8$

2.1 Accounting-Based Contractual Features . . . . . . . . . . . . . 8

2.2 Debt-Contracting Value and Renegotiation . . . . . . . . . . . . . 9

2.3 Debt-Contracting Value, Hold-up, and Underinvestment . . . . . . . . . . 11

3 Data and Sample Statistics $\quad 15$

4 Research Design $\quad 18$

4.1 Measure of Renegotiation . . . . . . . . . . . . . . . . . . . 18

4.2 Measure of Investment . . . . . . . . . . . . . . . . . . . 18

4.3 Measure of Debt-Contracting Value of Accounting Numbers . . . . . . . 18

4.4 Measures of Bargaining Power . . . . . . . . . . . . . . . . . . . . 20

4.5 Tests of H1: Ex Ante Determinants of Probability of Renegotiation . . . 22

4.6 Tests of H2: Impact of Debt-Contracting Value of Accounting on Investment 23

5 Empirical Results 
5.1 Estimation of Debt-Contracting Value of Accounting Numbers . . . . . . 25

5.2 Summary Statistics . . . . . . . . . . . . . . . 26

5.3 Ex Post Shocks, Debt-Contracting Value, and Renegotiation . . . . . . . 27

5.4 Ex Ante Determinants of Probability of Renegotiation . . . . . . . . . 28

5.5 Impact of Debt-Contracting Value on Investment . . . . . . . . . . . . 30

6 Additional Analyses 32

6.1 Alternative Debt-Contracting Value Measures . . . . . . . . . . . . . . . 32

6.2 Additional Analyses on Renegotiation . . . . . . . . . . . . . . . . . 34

6.3 Additional Analyses on Investment . . . . . . . . . . . . . . . . . . 38

6.4 Survival Analysis . . . . . . . . . . . . . . . . . . . 40

7 Voluntary Disclosure, Renegotiation, and Information Monopoly 41

7.1 Do Borrowers Disclose More before Renegotiation? . . . . . . . . . . . . 42

7.2 Do More Disclosures Lead to Better Renegotiation Outcomes? . . . . . . 43

8 Concluding Remarks $\quad 44$

Appendix I: A Stylized Simple Model Relating to H1 and H2 46

Appendix II: Procedures of Checking Renegotiation Status 51

Appendix III: Excerpts of Amendment Files $\quad 53$

Appendix IV: Variable Definitions and Data Sources $\quad 60$

$\begin{array}{ll}\text { References } & 66\end{array}$ 


\section{List of Tables}

1 Descriptive Statistics . . . . . . . . . . . . . . . 77

2 Composition of Renegotiation Cases . . . . . . . . . . . . . . . 78

3 Estimation of Debt-Contracting Value of Accounting Numbers . . . . . . 79

4 Summary Statistics for Multivariate Analyses . . . . . . . . . . . . 80

5 Loan-Quarter Level Incidence of Renegotiation Analyses across the DebtContracting Value of Accounting Numbers and Shocks . . . . . . . . . . 81

6 Ex Ante Determinants of Probability of Renegotiation . . . . . . . . . . 82

7 Underinvestment . . . . . . . . . . . . . . . . . . 84

8 Impact of the Debt-Contracting Value of Accounting Numbers on Invest-

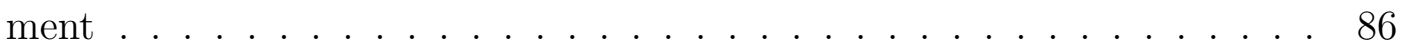

$9 \quad$ Alternative Debt-Contracting Value Measures . . . . . . . . . . . . . 88

10 Additional Analyses on Renegotiation . . . . . . . . . . . . . . . . . 89

11 Management Forecasts and Conference Calls around Debt Contract Ini-

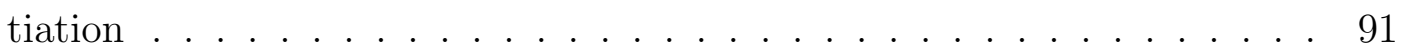

12 Impact of Management Forecasts and Conference Calls on Renegotiation

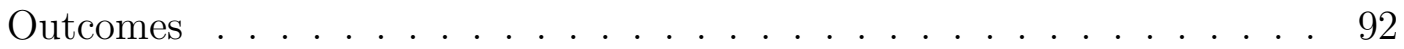




\section{List of Figures}

1 Time Line of Events in Each Period . . . . . . . . . . . . . . . . . . 47 


\section{Introduction}

Accounting information plays a crucial role in formal debt contracting. The accountingbased contractual features use accounting numbers as state-contingent signals to efficiently map economic conditions to a set of actions such as transfer of control rights (Smith and Warner 1979; Aghion and Bolton 1992). The contracting usefulness of these accounting variables depends on how well they measure the contracting constructs (e.g., future credit quality). While a number of recent studies argue that the most useful accounting numbers or measurement rules are chosen in debt contract originations to avoid costly renegotiation ex ante (El-Gazzar and Pastena 1990; Frankel and Litov 2007; Frankel et al. 2008; Beatty et al. 2008; Li 2010; Armstrong et al. 2010), there is no empirical evidence showing how the quality of accounting numbers affects the actual probability and the real cost of renegotiation.

In this thesis, I address these questions by investigating the influence of the debtcontracting value of borrowers' accounting numbers on the likelihood of private debt renegotiation and the implication of renegotiation for investment efficiency. The debtcontracting value captures the inherent ability of firms' accounting numbers to predict future credit quality (Ball et al. 2008). Specifically, when a shock occurs at some future time, the debt-contracting value of accounting captures the extent to which contracted accounting numbers at that future time reflect new information relevant to debt contracting.

I focus first on the impact of the debt-contracting value of accounting on the likelihood of renegotiation. In an incomplete contracting framework, ${ }^{1}$ the parties ex ante can

\footnotetext{
${ }^{1}$ If the parties to an agreement could specify their respective rights and duties for every possible future state of the world, their contract would be complete. The incomplete contract literature attributes the incompleteness into unforeseen contingencies, writing costs, enforcement costs, and complexity. See Dye (1985), Segal (1999), and Tirole (1999).
} 
only contract on some verifiable signals that are imperfectly related to the contracting constructs. After signing a contract, there is always room for Pareto-improving renegotiations once the contracting parties receive new information beyond the contracted signals. The parties trade off the gains from writing a more suitable contract against the costs of renegotiation. The size of the gains is affected by the ability of contracted accounting numbers to serve as verifiable signals to incorporate the new information. The higher the debt-contracting value of accounting, the less there is to gain by replacing the old contract. Consequently, the incentive to renegotiate should decrease. Thus, I hypothesize that firms with a higher debt-contracting value of accounting are less likely to renegotiate debt contracts. ${ }^{2}$

Further, I explore the real investment effects of renegotiation. While borrowers undertake all the costs of investment, the gains from borrowers' investment are partially shared by lending banks during the future renegotiations. Therefore, a higher anticipated probability of renegotiation reduces the ex ante investment incentive of the borrowers. Incomplete contract theory predicts that the borrowing firm will underinvest, which is also known as the hold-up problem (Williamson 1975, 1979; Klein et al. 1978; Aivazian and Callen 1980; Grossman and Hart 1986; Hart and Moore 1988, 1990). The degree of distortion depends on the perceived probability of renegotiation and the relative bargaining power of the parties involved. Lenders with more bargaining power

\footnotetext{
${ }^{2}$ The following is a simple example of "perfect" accounting that maximizes the debt-contracting value of accounting information at some future time when new information arrives. Consider a firm whose sole asset is a bond traded in deep and liquid markets, and the bond is marked to market each period. Any new information in future periods is reflected in the bond's carrying value, and there are no Pareto improvements from renegotiating the debt contract. As a further simple example, one indicating poor debt-contracting value of accounting numbers, consider a firm whose sole asset is one in-process $\mathrm{R} \& \mathrm{D}$ project. If internally generated intangibles are not capitalized and the project is still in-process at some future time when new information arrives, the accounting numbers will not at that future time reflect new information relevant to contracting. This gives rise, ex post, to Pareto improvements from renegotiating the debt contract. For most firms, the accounting will be somewhere between these polar extremes of perfect and poor quality of accounting numbers.
} 
can extract more gains, amplifying the effect of renegotiation on underinvestment. In an extreme case, if lenders have zero bargaining power and thus cannot obtain any gain from renegotiation, there is no underinvestment problem, and the expected probability of renegotiation is irrelevant.

The relative bargaining power is a function of the outside options for both contracting parties (Rubinstein 1982). For example, the informational advantage of incumbent lenders over outside lenders reduces the outside option of borrowing firms, because outside lenders face a "Winner's Curse" when competing with incumbent lenders in bidding for their clients (Sharpe 1990; Rajan 1992). I expect that firms with a higher debt-contracting value of accounting numbers have less underinvestment, and that the impact of the debt-contracting value on investment increases when lenders have more relative bargaining power. ${ }^{3}$

Private loan contracting provides a desirable empirical setting to investigate the implication of the debt-contracting value of accounting on renegotiation and investment efficiency for several reasons. First, private debt contracts frequently use accountingbased contractual features. For example, $96 \%$ of the contracts in my sample contain financial covenants. ${ }^{4}$ Second, the hold-up problem is more significant due to the informational advantage of incumbent lenders about borrowers over outside lenders. Finally, private debt has low renegotiation costs relative to public bond. After tracking 3,720 private loan agreements for 1,939 U.S. public borrowing firms, I find that $76 \%$ of loan contracts are renegotiated before maturity, and more importantly, that $75 \%$ of these

\footnotetext{
${ }^{3}$ Note that the hold-up problem does not conflict with borrowing firms' incentive to renegotiate contracts as long as lenders do not appropriate all the gains from renegotiation.

${ }^{4} \mathrm{My}$ sample period is from 1996 to 2005 . Covenant-lite loans with few maintenance covenants emerged in the U.S. in 2006. According to Standard \& Poor's Leveraged Commentary \& Data, covenantlite volume reached $\$ 97$ billion during the first six months of 2007 , representing $32 \%$ of overall loan issuance. However, between the summer of 2007 and late 2010, almost no covenant-lite loans were sold (Tett 2011).
} 
renegotiations involve changes in the accounting-based contractual features.

I estimate a direct proxy for the debt-contracting value of accounting by modifying the approach in Ball et al. (2008). ${ }^{5}$ My measure is a goodness-of-fit statistic from a Probit model where the levels of credit ratings are modeled as a function of lagged earnings, interest coverage ratios, leverages, and net worth, all of which are frequently used in accounting-based contractual terms. The debt-contracting value of accounting, $D C V$, is calculated at the industry level to capture how well accounting numbers predict future credit ratings.

To measure lenders' relative bargaining power, first, I use two characteristics of lenders, the proportion of institutional loans in a lead lender's total portfolio and the proportion of a syndicated loan deal held by foreign lenders. When lead lenders hold a greater proportion of institutional loans for sale on the secondary market, or when a higher proportion of a syndicated loan is held by foreign lenders, there are fewer incentives for lead lenders to collect information, reducing their informational advantage relative to outside competing banks (Sufi 2009). Therefore, lenders are in a weaker bargaining position. Second, I use two characteristics of borrowing firms, financial constraint and asset tangibility. Arguably, the higher financial constraint of borrowers reduces the possibility of refinancing, yielding more bargaining power for lenders. After signing contracts, when borrowers have fewer tangible assets, which cannot be easily sold by lenders, lenders have less bargaining power (Bergman and Callen 1991; Benmelech and Bergman 2008).

The results of cross-sectional analyses show that increasing the debt-contracting value of accounting numbers from the first quartile to the third quartile decreases the probability of renegotiation by $6 \%$. I also find significantly less investment by borrowing

\footnotetext{
${ }^{5}$ Using the original debt-contracting value measure of Ball et al. (2008) does not affect my inferences.
} 
firms in capital expenditures and R\&D than would be expected based on investment fundamentals in the period after entering a private debt agreement, and before renegotiation or before maturity in cases where there is no renegotiation. Additional tests using matched control firms suggest that sample firms invest less than the firm itself in the same period of the previous year or relative to peers matched by year, industry, and sales growth. Lower investment by my sample firms leads to a poorer future operating performance. Furthermore, I find that a positive shift in the debt-contracting value of accounting increases borrowers' investment, and that the increase is larger when lenders have more relative bargaining power. My empirical findings are robust to (1) additional measures of the debt-contracting value of accounting numbers (at both the industry level and the firm level), (2) a battery of alternative explanations on renegotiation, (3) alternative explanations on investment, and (4) different model specifications.

This study makes several contributions to the literature. First, it extends the literature on the choice of accounting numbers/rules in private debt contracts. Prior studies focus on how accounting variables are chosen and adjusted through negotiated measurement rules in debt contracting, arguing that the most relevant accounting numbers/rules are chosen in debt originations to avoid costly renegotiation ex ante (El-Gazzar and Pastena 1990; Frankel and Litov 2007; Frankel et al. 2008; Beatty et al. 2008; Li 2010; Armstrong et al. 2010). However, there is no evidence showing that a better quality of accounting numbers actually reduces the probability of renegotiation. Relying on incomplete contract theory, I provide large-sample evidence of the negative relation between the debt-contracting value of accounting and the likelihood of renegotiation. Armstrong et al. (2010, 227) state, "[T]here has been relatively little research on the role of accounting reports in the renegotiation process." This thesis fills this gap, and to my knowledge is one of the first to investigate the cross-sectional impact of low quality 
accounting numbers on debt renegotiation.

Second, this thesis complements the accounting literature on the effect of debt contracts on accounting choice. One of the primary testable implications of positive accounting theory is the debt covenant hypothesis (Watts and Zimmerman 1990). According to this hypothesis, managers have incentives to reduce the likelihood of accounting-based covenant violation through their accounting discretion. However, the extant empirical evidence is mixed (Healy and Palepu 1990; DeAngelo et al. 1994; DeFond and Jiambalvo 1994; Sweeny 1994; Dichev and Skinner 2002). Moreover, Holthausen (1981) and Leftwich (1981) find limited results by detecting the effect of cosmetic accounting changes on stock returns. Holthausen and Leftwich (1983) contend that the agency cost of accounting discretion is bounded above by the costs of renegotiation. In other words, depending on which cost is lower, managers either use accounting discretion to avoid covenants violation or renegotiate a new contract. In the private loan setting, renegotiation costs with lenders are reasonably low when compared to the costs of renegotiating with a large and diverse set of bondholders. My finding of frequent renegotiations related to accounting-based contractual terms suggests that instead of manipulating accounting numbers, firms may renegotiate a new set of covenants, providing a potential explanation for the weak findings of the debt covenant hypothesis. ${ }^{6}$

Third, by addressing the hold-up problem, this study provides a new avenue to answer one of the fundamental questions in accounting: how does financial reporting quality affect investment efficiency? Generally, the prior literature claims that a higher quality of accounting numbers mitigates moral hazard and adverse selection problems, thus enhancing investment efficiency (Kanodia and Lee 1998; Bens and Monahan 2004; Biddle and Hilary 2006; Hope and Thomas 2008; McNichols and Stubben 2008; Biddle

\footnotetext{
${ }^{6}$ See Barton and Simko (2002) and Baber et al. (2011) for situations where earnings management is very costly.
} 
et al. 2009; Beatty et al. 2010a; Chen et al. 2011b). This thesis identifies a different channel by which a higher quality of accounting numbers (i.e., higher debt-contracting value of accounting numbers) improves investment efficiency. Incomplete contract theory predicts that ex post renegotiation reduces the incentive for ex ante investment, resulting in the problem of underinvestment. I find that a higher debt-contracting value of accounting mitigates the underinvestment problem by reducing the probability of renegotiation, and that this effect increases with lenders' relative bargaining power. ${ }^{7}$

Finally, this thesis extends Roberts and Sufi (2009a) by identifying key ex ante determinants of the probability of renegotiation. In their Probit analyses, none of the firm characteristics at origination load in explaining renegotiation. ${ }^{8}$ I argue that the incentive for ex post renegotiation comes from a lower quality of contractual accounting numbers and find that a higher debt-contracting value of accounting numbers significantly decreases the likelihood of renegotiation.

The next section develops the testable hypotheses. Section 3 shows descriptive statistics on the renegotiation. Section 4 explains the research design choices. Section 5 presents evidence on the relation among the debt-contracting value of accounting, the likelihood of renegotiation, and investment efficiency. Section 6 discusses additional robustness tests. Section 7 provides analyses on voluntary disclosures before renegotiation, while Section 8 concludes. Appendix I develops a stylized analytical model that both motivates and supports the empirical analyses. ${ }^{9}$

\footnotetext{
${ }^{7}$ Neither adverse selection nor moral hazard can predict this interaction effect, namely, that the impact of the debt-contracting value of accounting on investment increases with lenders' relative bargaining power.

${ }^{8}$ The firm characteristics include log assets, debt-to-EBITDA, book leverage, market-to-book, EBITDA/assets, and EBITDA volatility.

${ }^{9}$ The model is a simplified version of Rajan (1992) augmented with an accounting component. In Rajan (1992), there is no state-contingent contractible variable (accounting number), and therefore he only examines two extreme cases: (1) long-term contract, where there is absolutely no renegotiation; (2) short-term contract, where there must be a renegotiation to renew the contract during interim. This simple model fits in between and can generate the implication of the debt-contracting value of
} 


\section{Background and Hypotheses Development}

\subsection{Accounting-Based Contractual Features}

Debt contracts typically contain financial covenants, performance pricing and/or borrowing bases ${ }^{10}$ all of which are usually based on accounting numbers. ${ }^{11}$ These accountingbased contractual features use accounting numbers as state-contingent signals to efficiently map economic conditions to a set of actions (e.g., transfer of control rights, change of interest rates, change of credit commitment, etc.) and prevent both parties from engaging in value-destroying actions due to divergent interests.

Specifically, accounting-based covenants transfer certain decision rights to creditors in states of deteriorating financial performance, in which borrowers have greater incentives to take actions detrimental to firm values (Aghion and Bolton 1992; Nini et al. 2009b). Performance pricing allows both parties to commit, ex ante, to adjust interest rates on the debt contract when there are changes in the borrower's credit quality, thereby reducing the potential for renegotiation costs, hold-up problems, and other potential conflicts (Asquith et al. 2005; Armstrong et al. 2010). A borrowing base is a type of credit line, for which fund availability is tied to the borrower's accounts receivable, inventory, etc. It allows lenders' actual exposure to vary with the borrowers' success (Flannery and Wang 2011). The usefulness of these accounting-based contractual features depends on the extent to which the contracted accounting numbers reflect the relevant information for debt contracting.

accounting.

${ }^{10}$ Appendix III provides examples of these contractual features.

${ }^{11}$ Performance pricing can also be based on credit ratings. See Ball et al. (2008) and Costello and Wittenberg-Moerman (2011) for the choice between accounting numbers and credit ratings. 


\subsection{Debt-Contracting Value and Renegotiation}

The accounting numbers generated under Generally Accepted Accounting Principles (GAAP) usually cannot fully capture the constructs of interests to private debt market participants. Contracting parties tend to adjust the accounting numbers systematically to improve contracting efficiency (Leftwich 1983; Beatty et al. 2008; Li 2010). For example, closely examining 3,720 private debt contracts, Li (2010) discovers that in the contractual definition of net income, $23 \%$ of the contracts exclude extraordinary items, which are perceived to be less informative about future performance. ${ }^{12}$

Although the pre-determined formulaic adjustment helps to refine the contractual accounting numbers, it cannot completely offset their imperfections. Contracting on customized accounting numbers involves the costs of ascertaining the optimal contracting variables and additional costs of monitoring with more complicated measurement rules. The costs are so high ex ante that contracting parties deliberately accept imperfect accounting-based terms.

Once the contracted accounting numbers fail to reflect ex post new relevant information for debt contracting, indicating inefficient actions (e.g., transferring the control right to creditors unnecessarily), borrowers and lenders have an incentive to renegotiate contractual terms. ${ }^{13}$ They trade off the gains from writing a more suitable contract

\footnotetext{
${ }^{12}$ This thesis uses the same private debt agreements sample. Instead of studying the ex ante contract design, I focus on the ex post renegotiation probability and investment efficiency.

${ }^{13}$ Fleetwood, of Riverside, Calif., was the nation's largest manufacturer of recreational vehicles (RV) and a leading producer and retailer of manufactured housing. Its business woes began in early 2000 just as the Internet bubble began to burst. The company closed 16 manufactured housing and four RV factories, and later laid off about $32 \%$ of its workforce. However, it maintained its number one position in the RV sector. To meet debt contract requirements, Fleetwood needed to have EBITDA of $\$ 17.7$ million in the second quarter, and these figures were not going to be met. On December 10, 2001, the company successfully renegotiated a new contract with the Bank of America. One of the amended items was the replacement of the EBITDA covenant. Instead, there was a free cash flow covenant that took into account a whole range of factors, including capital expenditure and service on junior subordinated debt. One year later, the restructuring was successful and Fleetwood gradually recovered from the difficult time. In contrast, according to the original contract, technical default could transfer the control right to lenders. Since the EBITDA covenant sent a false alarm, and the Bank of America
} 
against the costs of renegotiation. ${ }^{14}$ The gains of more suitable contracts could come from fewer false alarms of covenant violations (Gigler et al. 2009), a more flexible environment to explore investment opportunities (Roberts and Sufi 2009a), and better incentives for managers to make subsequent decisions (Gorton and Kahn 2000). Of course, these renegotiations are not costless. Both parties need to spend time and effort to understand the transaction.

A higher debt-contracting value of accounting numbers helps to incorporate news into contracts directly, reducing the size of the potential gains from renegotiations. ${ }^{15}$ This yields my first hypothesis:

H1: Ceteris paribus, firms with a higher debt-contracting value of accounting numbers have a lower likelihood of renegotiating their private debt contracts.

When designing the initial contract, rational contracting parties take into account the quality of accounting numbers. A growing literature documents that a lower quality of borrowers' accounting numbers (e.g., a lower debt-contracting value of accounting) leads to higher interest rates, shorter maturities, less use of financial covenants and accounting-based performance pricing provisions, more use of credit-rating-based per-

did not have the expertise to manage Fleetwood, hindsight suggests that letting the lender intervene is not better than waiting for the recovery.

${ }^{14}$ There may be an informational wedge between borrowing firms and lenders. However, theories of financial intermediation highlight the special role of banks in private information production and mitigation of informational asymmetries in an imperfect capital market (Leland and Pyle 1977; Campbell and Kracaw 1980; Diamond 1984, 1991). Lenders require private information regarding a borrower before making a lending decision as well as periodic reporting of private information after a loan has been made (Standard \& Poor's 2007). Moreover, renegotiation is usually initiated by borrowers, and they have an incentive to provide more information to minimize the informational wedge (Taylor and Sansone 2007).

${ }^{15}$ Arguably, higher debt-contracting value of accounting may ease the renegotiation process and lower the costs. This could also generate the prediction of H1, but the effect of debt-contracting value should not depend on the magnitude of shocks based on this argument. See section 5.3. 
formance pricing provisions, and more collateral requirements (Ball et al. 2008; Bharath et al. 2008; Graham et al. 2008; Costello and Wittenberg-Moerman 2011; Christensen and Nikolaev 2011; Kim et al. 2011). If these contracting terms are perfect substitutes for accounting-based contractual features, one should not expect a relation between the debt-contracting value of accounting numbers and any ex post renegotiation after controlling for these loan characteristics. Thus, whether $\mathrm{H} 1$ holds is ultimately an empirical question.

Debt contract renegotiation is not completely new in accounting research. One of the consequences of covenant violations is the amendment of the original contract (Beneish and Press 1993; Chen and Wei 1993). For example, based on 126 covenant violation cases, Beneish and Press (1993) find that on average, the loan interest rate increases 80 basis points, and the number of covenants increases by 27\%. Chen et al. (2011a) expand the violation sample and find that parties' relative bargaining power determines the outcome in the bargaining process after a violation. However, in my sample, only $17 \%$ of renegotiation cases are triggered directly by covenant violations. ${ }^{16}$

\subsection{Debt-Contracting Value, Hold-up, and Underinvestment}

In the renegotiation process, borrowers and lenders discover how to improve the original contracts, and split the incremental gains from the new contract according to their relative bargaining power. Since either party can simply reject a renegotiation proposal as long as the party has a better alternative, the relative bargaining power is a function of the outside options for both contracting parties (Rubinstein 1982).

On the borrowers' side, their outside option of finding a refinancing source is significantly reduced by incumbent banks' informational advantage about the borrowers

\footnotetext{
${ }^{16} \mathrm{My}$ results are robust to excluding renegotiations triggered by covenant violations.
} 
relative to outside banks (Sharpe 1990; Rajan 1992). Rajan (1992) examines competition between an informed "inside" bank that is already lending to a risky firm, and an uninformed "outside" bank that is not currently lending to the firm. The inside bank knows whether the firm will succeed or fail, whereas the outside bank only knows that the firm will succeed with a certain probability. In this situation, if the outside bank makes a bid to lend to the firm, it faces the "Winner's Curse." As the inside bank only bids for the loan when it knows that the firm will succeed, the outside bank is more likely to win the loan when the firm is failing. ${ }^{17}$ In equilibrium, the uninformed banks use mixed strategies. In other words, they only bid with a probability less than one, which constrains the outside option of the borrowers. Therefore, the incumbent banks partially hold monopolistic positions and share part of the benefit of the borrowing firm's investment. ${ }^{18}$

Empirical studies find evidence consistent with the theory of information monopoly (Houston and James 1996; Bharath et al. 2008; Santos and Winton 2008; Hale and Santos 2008; Schenone 2010; Ioannidou and Ongena 2010). For example, using detailed data from Bolivia, Ioannidou and Ongena (2010) show that a loan granted by a new (outside) bank carries a loan rate that is significantly lower than the rates on comparable new loans from the firm's current inside banks. The new bank initially decreases the loan rate further but eventually ratchets it up sharply. The evidence is consistent with the incumbent banks being able to hold up borrowers.

On the lenders' side, their outside option (bargaining power) is reduced when borrowers' liquidation value is low, because it is hard for them to liquidate borrowers'

\footnotetext{
${ }^{17}$ The intuition here parallels that of information risk in the equity market in a rational expectation framework (Easley and O'Hara 2004). Rajan's theory is based on auction theory and does not rely on the shocks of assets supply, which is a key assumption in rational expectation equilibrium.

${ }^{18}$ It is consistent with the finding of Roberts and Sufi (2009b) that borrowers rarely switch lenders following a violation.
} 
assets when borrowing firms' credit conditions deteriorate (Bergman and Callen 1991; Benmelech and Bergman 2008). For example, Benmelech and Bergman (2008) find that airlines successfully renegotiate their lease obligations downward when the liquidation value of their fleet is low.

Due to the fear of lenders' rent extraction in ex post renegotiation, borrowers will underinvest before the renegotiation (Williamson 1975, 1979; Klein et al. 1978; Aivazian and Callen 1980; Grossman and Hart 1986; Hart and Moore 1988, 1990). The distortion depends on the magnitude of the expected rent extraction, which is the product of the perceived probability of renegotiation and creditors' relative bargaining power. Decreasing the perceived probability of renegotiation reduces the underinvestment, ${ }^{19}$ and this effect increases with creditors' relative bargaining power.

Take a simple exercise, for example. If a borrowing firm faces an investment decision $I$ of a project with returns of $r(I)=I^{1 / 2}$, where $I$ is the investment amount and $r($.$) is an increasing and concave function. To maximize its profit I^{1 / 2}-I$, the firm's optimal investment level $I^{F B}=\frac{1}{4}$ should solve $\frac{1}{2} \frac{1}{\sqrt{I}}-1=0 . \quad F B$ and $S B$ indicate the first best and the second best, respectively. Suppose that with a probability of $p \in(0,1)$, a lender can share $\beta \in(0,1)$ of the returns through the renegotiation process. Then the objective function of the borrower becomes $(1-p \beta) I^{1 / 2}-I$, and the optimal investment level solving $(1-p \beta) \frac{1}{2} \frac{1}{\sqrt{I}}-1=0$ is $I^{S B}=\frac{1}{4}(1-p \beta)^{2}$, lower than $I^{F B}$. The distortion $I^{F B}-I^{S B}$ is an increasing function of the probability of renegotiation $\frac{\partial\left(I^{F B}-I^{S B}\right)}{\partial p}=\frac{\partial p \beta(2-p \beta)}{\partial p}=\beta(2-p \beta)>0$ and the slope increases with lenders' bargaining

\footnotetext{
${ }^{19}$ Since rational contracting parties can adjust accounting-based contracting terms in initial contracts when anticipating poor performances due to underinvestment (Douglas 2003), underinvestment should not increase the probability of renegotiation. If the adjustment is incomplete and a lower debt-contracting value of accounting increases the likelihood of renegotiation only through causing underinvestment (Biddle et al. 2009), the relation between the debt-contracting value of accounting and the probability of renegotiation should only hold for firms experiencing bad news. See section 5.3 for cases of firms having good news.
} 
power $\frac{\partial^{2}\left(I^{F B}-I^{S B}\right)}{\partial p \partial \beta}=\frac{\partial \beta(2-p \beta)}{\partial \beta}=2 p(1-p \beta)>0$.

The above discussion yields my second set of hypotheses:

H2a: Ceteris paribus, firms with higher debt-contracting value of accounting have less underinvestment, because the probability of renegotiation is perceived to be lower.

$\mathrm{H} 2 \mathrm{~b}:$ Ceteris paribus, the impact of the debt-contracting value of accounting on investment increases when lenders have more relative bargaining power.

The underinvestment problem can be solved if both parties can commit to not renegotiate initial contracts. However, this commitment is never credible and enforceable, given the ex post mutual benefit for both parties. Note that the hold-up problem does not conflict with borrowers' incentive to renegotiate as long as lenders do not appropriate all the gains from renegotiation.

Although the underinvestment problem is developed through incomplete contract theory, it is similar to Myers' (1977) underinvestment (debt overhang) problem in the sense that the distortion is driven by lenders sharing the benefit but not the cost of investment. In Myers (1977), sharing of the benefit is due to the possibility of a firm's asset-in-place being lower than the face value of debt rather than rent extraction during renegotiation. In addition, Myers (1977) argues that other institutional arrangements are unlikely to eliminate the problem. One example is the difficulty of finding a perfect contractible variable to govern the investment decisions efficiently, which could be partially attributed to a low debt-contracting value of accounting numbers. In the following analyses, I control for Myers' underinvestment problem following Hennessy et al. (2007). They construct a debt overhang correction variable $(R K)$, which is the product of long-term debt scaled by the capital stock, recovery ratio, and the value of the claim 
paying one dollar at default.

\section{Data and Sample Statistics}

I start with 3,720 original debt contracts extracted from SEC filings by Nini et al. (2009a). ${ }^{20}$ I merge the contract data with Compustat through Gvkey and with Dealscan through DealScan name and date given in the dataset. Panels A and B of Table 1 present the mean borrower and loan characteristics, respectively. The median deal amount of $\$ 190$ million is about twice the value reported in Dichev and Skinner (2002) for the DealScan-Compustat intersection sample. This indicates that the sample is biased toward large loan contracts, which is not surprising because debt contracts are required to be filed only when the debt amounts are material (exceed $10 \%$ of total assets). ${ }^{21}$ $95.8 \%, 50.1 \%$, and $19.7 \%$ of debt contracts have financial covenants, accounting-based performance pricing, and accounting-based borrowing bases, respectively.

Besides material contracts, Regulation S-K item 601 also requires all amendments to be filed with an 8-K, 10-K, or 10-Q. I first randomly pick 100 contracts, and manually search the $10-\mathrm{K}, 10-\mathrm{Q}$, and $8-\mathrm{K}$ of borrowing firms after the initiation of each contract for any mention of changes in any major contractual terms including principal, interest, maturity, and accounting-based contractual terms. Accounting-based contractual terms include financial covenants, accounting-based performance pricing, and accounting-based borrowing bases. Implicit in this strategy is a definition of rene-

\footnotetext{
${ }^{20}$ Nini et al. (2009a) begin with a sample of loans from Reuters LPC's DealScan database that are matched to firm financial variables from Standard \& Poor's COMPUSTAT for the years 1996 through 2005. They then use text-search programs to scan SEC filings in Edgar for loan contracts and match the contracts to DealScan based on the dates of the loan agreements and the names of the companies. Their final sample consists of 3,720 loan agreements for 1,939 borrowers. In their Appendix A, they further show that the search algorithm does not lead to any meaningful bias.

${ }^{21}$ I also use other publicly available data sources such as I/B/E/S and Thomson Reuters to generate my control variables (see Appendix IV for details). The number of observations for each regression may vary due to the availability of some variables.
} 
gotiation as any ex post change to these terms. Focusing on the first amendment, I find that $67 \%$ of the contracts are renegotiated.

Second, I download all the filings containing the amendments or renegotiated contracts and develop a search algorithm (see Appendix II for details) using Perl based on these 67 manually collected filings. I then apply this algorithm to the 10-K, 10-Q, and 8-K filings of borrowing firms of the remaining 3,620 contracts. The algorithm captures all 67 renegotiation cases in my pilot sample. However, it also indicates many false alarms. Therefore, after extracting blocks of texts, I read through each of them to make sure that they are truly debt contract renegotiations.

I identify 2,819 contracts that are renegotiated before maturity. ${ }^{22}$ For the contracts without renegotiation, 355 of them stop filing before maturity. By searching Compustat footnotes and the Internet, I find that most of them disappear due to mergers and acquisitions, Chapter 11 bankruptcy protection, or going private. ${ }^{23}$

Table 2 Panel A presents the results after comparing the 2,819 amendment files with the original contracts. I provide both the unconditional and conditional probability estimates. Unconditionally, $75.8 \%$ of contracts are renegotiated with respect to major contractual terms. I calculate the incidences conditional on three events (Event A, B, and $\mathrm{C}$ ). Given any major contractual term being renegotiated (Event A), $74.7 \%$ of the renegotiations involve changes of accounting-based contractual terms. ${ }^{24}$ Within the renegotiations related to changes in accounting-based terms (Event B), 90.7\%, 34.8\%, and $10.4 \%$ of the renegotiation cases involve amendments to accounting-based covenants,

\footnotetext{
${ }^{22}$ This finding is consistent with Roberts and Sufi's (2009a) estimate and Liu and Ryan's (1995) claim that commercial loans are frequently renegotiated.

${ }^{23}$ Deleting them does not affect my results. See section 6.4 for formally correcting the bias of rightcensoring in a hazard model.

${ }^{24}$ For comparison, given Event A, 47.2\%, 46.4\%, and 43.7\% of renegotiations involve changes of maturity, principal, and interest, respectively. Roberts (2010) also finds that the most frequently changed items are covenants using accounting measures.
} 
accounting-based performance pricing, and accounting-based borrowing bases respectively (see Appendix III for five examples). The sum of the percentages in column $\operatorname{Pr}(. \mid B)$ is greater than one because, often, more than one term is changed in a renegotiation. Since performance pricing and borrowing bases are less frequently used than financial covenants, I also calculate the percentage conditional on the existence of the contractual term in the corresponding row (Event C). For example, conditional on a contract having an accounting-based borrowing base, there is a $30.1 \%$ chance of amending this borrowing base subsequently.

Table 2 Panel B breaks down the renegotiations of accounting-based covenants by type. The top three frequently amended financial covenants (i.e., debt-to-cash flow/earnings, fixed charge coverage, and interest coverage) use accounting numbers from the income statement. This pattern parallels the findings of Li (2010) and Demerjian (2011) that the modification of accounting numbers from the income statement in original contracts is more frequent than that from the balance sheet. The probability of renegotiating each financial covenant conditional on the existence of that particular covenant ranges from $12.9 \%$ to $44.6 \%$, and is presented in column $\operatorname{Pr}(. \mid C)$.

Table 2 Panel $\mathrm{C}$ classifies the accounting-related renegotiation cases by action. In particular, $72.4 \%$ of the cases simply change the threshold (see Appendix III example 2), and $41.9 \%$ of them redefine the accounting-based contractual terms (see Appendix III example 1). Adding and deleting financial covenants are also adopted in $21 \%$ and $19 \%$ of the cases, respectively (see Appendix III example 3). The results in Table 2 are very similar if I delete renegotiations due to covenant violations. ${ }^{25}$

\footnotetext{
${ }^{25}$ I use the violation data from Nini et al. (2009b). They identify the covenant violations of each firm-quarter by searching keywords from SEC filings.
} 


\section{Research Design}

\subsection{Measure of Renegotiation}

For the main analysis, I create an indicator variable $R E N E G$ that takes the value of one if any major terms of a contract are renegotiated before maturity. The cross-sectional variation of duration between loan initiation and renegotiation is further explored in a survival analysis in section 6.4. For robustness, I also construct an index capturing how intensively the renegotiations are related to changes in accounting-based contractual terms and estimate a negative binomial model in section 6.2.

\subsection{Measure of Investment}

Starting from the quarter after signing the debt contract and ending with the quarter before renegotiation or before maturity in cases where there is no renegotiation, I take the average of quarterly capital expenditures plus R\&D scaled by total assets. ${ }^{26}$

\subsection{Measure of Debt-Contracting Value of Accounting Num- bers}

I conceptualize the debt-contracting value of accounting as the ability of contracted accounting numbers to capture future states, in particular future credit-rating levels. ${ }^{27}$ The original $D C V$ from Ball et al. (2008) captures how well lagged seasonally-adjusted changes in earnings predict future credit rating downgrades. Since I am interested in the explanatory power of variables actually used in contracts (i.e., the contracting role of accounting numbers), and since accounting-based contractual terms are written in terms

\footnotetext{
${ }^{26}$ Deleting non-renegotiation cases in investment analyses yields similar results.

${ }^{27} \mathrm{My}$ results are robust to three alternative measures of debt-contracting value of accounting numbers. See section 6.1.
} 
of levels, I choose to use the level specification. Table 2 shows that besides earnings, various coverage ratios, leverage, and net worth are used and amended in covenants. Therefore, I augment the model by adding coverage ratios, leverage ratios, and net worth. For any given year, I estimate an Ordered Probit Model using quarterly data in the past five years for each Fama-French industry (48 categories):

$P\left(\right.$ Rating $\left._{t, i} \leq N\right)=\Phi\left(\sum_{n=1}^{N} \mu_{n}+\sum_{k=1}^{4} \alpha_{k} E_{t-k, i}+\sum_{k=1}^{4} \beta_{k} C O V_{t-k, i}+\sum_{k=1}^{4} \gamma_{k} L E V_{t-k, i}+\sum_{k=1}^{4} \delta_{k} N W_{t-k, i}\right)$

where Rating $_{t, i}$ is assigned 1 to companies with the highest S\&P credit rating in quarter $t, 2$ to companies with the second-highest credit rating, and so on. $E_{t-k, i}$ is EBITDA divided by total assets in quarter $t-k . C O V_{t-k, i}$ is interest coverage (EBITDA divided by total interest expense). ${ }^{28} L E V_{t-k, i}$ is long-term debt divided by total assets in quarter $t-k . N W_{t-k, i}$ is net worth divided by total assets. Each regression requires at least 100 firm-quarter observations. Specifically, $D C V$ is measured as Somers' D, a goodness-of-fit statistic. ${ }^{29}$ The higher $D C V$, the higher is the predictive ability of accounting numbers for credit ratings. ${ }^{30}$ The oil and gas industry is in the lowest tercile of the distribution, which is not surprising given the large uncertainty and accounting discretion in this industry (Malmquist 1990; Aboody 1996).

\footnotetext{
${ }^{28}$ Using the same sample of debt contracts, Li (2011) observes that EBITDA is the most frequently used form of earnings.

${ }^{29}$ Beatty (2008) points out that Somers' D depends on the true underlying probability of default in each estimation group. I include both Altman's zscore and credit ratings fixed effects in the main analyses. In addition, my main results are robust to using pseudo $R^{2}$ instead of Somers' D.

${ }^{30}$ Somers' $\mathrm{D}$ is a statistic of association between observed ratings and model predicted ratings. Specifically, it is calculated as $\left(n_{c}-n_{d}\right) / t$, where $t$ is the total number of paired observations with different responses in the sample (i.e., different ratings), $n_{c}\left(n_{d}\right)$ is the number of concordant (discordant) pairs. A pair of observations is said to be concordant (discordant) if the observation with the lower ordered response value (i.e., the best rating) has a lower (higher) predicted mean score than the observation with the higher ordered response value (i.e., the worst rating). The predicted mean score of an observation is the sum of the ordered values minus one, weighted by the corresponding predicted probabilities for that observation.
} 
Contracting parties normally choose their own measurement rules for accountingbased terms, as the use of accounting GAAP variables could induce noise. Li (2010, 2011) closely examines the same agreements sample as I use in this study and finds that the most frequently excluded terms in net income are extraordinary items (23\%), and that the most frequently excluded accrual items are long-term accruals $(80 \%$ in the interest coverage sample, $89 \%$ in the fixed charge coverage sample, and $96 \%$ in the debtto-earnings sample). Therefore, I use earnings before extraordinary items, depreciation, and amortization in the regression. Section 6.2 also presents a test that takes into account all contractual adjustments for a small sample.

\subsection{Measures of Bargaining Power}

To capture contracting parties' relative bargaining power, I use two characteristics of lenders, the proportion of institutional loans in the lead lender's total portfolio and the proportion of a syndicated loan deal held by foreign lenders, and two characteristics of borrowing firms, financial constraint and asset tangibility.

First, I calculate the proportion of institutional loans in the portfolio of lead lenders, multiplied by minus one (INSTLP). ${ }^{31}$ Wittenberg-Moerman (2008) finds that institutional investors constitute the main participants in the secondary loan market and that institutional loans represent $45 \%$ of traded loans during the sample period. When the loan is originated for sale on the secondary market, lenders have fewer incentives to acquire information and monitor the borrowers (Pennacchi 1988; and Gorton and Pennacchi 1995). Moreover, if the portfolio of a lead lender consists of a large proportion of institutional loans, the lead lender is probably an institutional investor rather than a

\footnotetext{
${ }^{31}$ For INSTLP, I focus on the lead lender(s) of a particular loan facility, as it is frequently the administrative agent that has the fiduciary duty to other syndicate participants to provide timely information about the borrower (Taylor and Sansone 2007).
} 
bank and has a weak information monopoly relative to outside lenders. The higher the value that INSTLP takes, the more relative bargaining power lenders have.

Second, I use the proportion of the syndicated loan deal held by foreign lenders multiplied by minus one (FLENDER). A larger proportion of the syndicated loan owned by foreign lenders leads to fewer incentives for lead lenders to collect borrowers' information (Sufi 2009); therefore, the information monopolistic position of incumbent banks is weakened. A higher value of FLENDER suggests more relative bargaining power of lenders.

Third, since most private debt agreements do not carry considerable prepayment penalties (Roberts and Sufi 2009a), the ease of finding another source of financing to a borrower significantly reduces lenders' bargaining power. I use the Kaplan-Zingales index of financial constraint (Kaplan and Zingales 1997) as another measure (KZIND). The lenders' bargaining power increases when borrowing firms are more financially constrained.

Finally, I calculate the asset tangibility $(T A N G)$ of borrowers following Berger et al.'s (1996) formula to proxy for creditors' ex post bargaining power under renegotiation (Bergman and Callen 1991; Benmelech and Bergman 2008). The lower the value of $T A N G$, the less bargaining power creditors have, because creditors' outside option - to sell the repossessed asset - is not very attractive. 


\subsection{Tests of H1: Ex Ante Determinants of Probability of Rene- gotiation}

Using the cross-sectional sample of 3,720 debt contracts, I estimate a Probit model following Roberts and Sufi's (2009a) specification and add DCV to the regression:

$$
P\left(\text { Renegotiation }_{t, i}=1\right)=\Phi\left(\alpha_{0}+\beta_{1} D C V_{t, i}+\mathbf{X}_{\mathbf{t}, \mathbf{i}}^{\prime} \zeta\right)
$$

where $D C V_{t, i}$ is the debt-contracting value of accounting numbers before signing the contract, and $\mathbf{X}_{\mathbf{t}, \mathbf{i}}$ contains ex ante determinants of renegotiation, including firm characteristics, deal characteristics, lender characteristics, deal purpose fixed effects, year fixed effects, and credit rating fixed effects.

All the determinant variables are calculated using data before loan initiation. Specifically, for firm characteristics, I include log of assets (LNASSET); debt-to-EBITDA ratio (DTE); book leverage ( $L E V)$; return on assets $(R O A)$; return on assets volatility (STDROA); Altman's zscore (ZSCORE); asset tangibility (TANG); and the KaplanZingales financial constraint index $(K Z I N D)$.

For deal characteristics, I include log of stated maturity (LNMATURITY); loan spread (SPREAD); number of lenders (NLENDER); log of deal amount scaled by assets $(D A M O U N T)$; an indicator variable equal to one for the presence of a revolving line of credit $(R E V L V)$; an indicator variable equal to one if a tranche contains performance pricing $(P G) ; 32$ an indicator variable equal to one for the presence of a borrowing base $(B O W B A S E)$; an indicator variable equal to one for the presence of any income-statement-based covenant (COVIS); an indicator equal to one for the presence of any balance-sheet-based covenant $(C O V B S)$; an indicator equal to one if collateral

\footnotetext{
${ }^{32}$ If I instead use a binary variable indicating whether a tranche contains credit-rating-based performance pricing, no inferences in the following are affected
} 
is required $(C O L L)$; and lending relationship intensity $(R E L I N T)$. All the variables at tranche level (LNMATURITY, SPREAD, REVLV, PG, BOWBASE, COLL, and $R E L I N T)$ are aggregated to the deal level by taking an average, weighted by the amount of each tranche.

Finally, I include two lender characteristics, the proportion of institutional loans in lead lenders' portfolio, multiplied by minus one (INSTLP), and the proportion of a syndicated loan deal held by foreign lenders, multiplied by minus one (FLENDER). All the variables are defined in Appendix IV. Since some firms may have multiple deals and have thus entered into my sample multiple times, I calculate the standard errors clustered by firm (Petersen 2008). ${ }^{33}$ If the hypothesis (H1) that $D C V$ reduces the likelihood of renegotiation is true, I expect $\beta_{1}<0$.

\subsection{Tests of H2: Impact of Debt-Contracting Value of Ac- counting on Investment}

To test my second hypothesis, I first examine whether the sample firms underinvest. I identify abnormal investment as investment that differs from the amount that would be predicted given the firm's investment opportunities, using a model motivated by the finance and economics literature on optimal investment. Specifically, for each sample firm, I calculate INVEST in the same period as the sample firm for the other Compustat firms in the same year and 2-digit SIC industry. I then pool the sample firm together with the Compustat firms and estimate the regression: INVEST $=\theta_{1}+\theta_{2} Q+\theta_{3} C F+u$, where $u$ is a zero mean error term, $Q$ is Tobin's $\mathrm{Q}$, and $C F$ indicates cash flow. Abnormal investment is measured by the residuals from this regression.

In addition, I examine the sensitivity of my findings to two alternative estimates of

\footnotetext{
${ }^{33}$ Clustering by industry provides even stronger results.
} 
expected investment: (1) the investment of the same firm during the same period of the previous year, and (2) the investment of a control firm matched by year, industry (2-digit SIC), and sales growth. I expect the abnormal investment of my sample firms to be negative.

To emphasize that the impact on investment is through the perceived probability of renegotiation, I calculate the predicted probability of non-renegotiation driven by the debt-contracting value ( $R E N E G D C V)$. Specifically, it is calculated as one minus the predicted value by plugging $D C V$ and the means of other independent variables using the coefficients from column (2) of Table 6. Thus, the higher RENEGDCV, the less likely it is that there will be a renegotiation. To test if higher $D C V$ increases corporate investment (H2a), I estimate the following regression: ${ }^{34}$

$$
I N V E S T=\gamma_{0}+\delta_{1} R E N E G D C V_{t, i}+\mathbf{Y}_{\mathbf{t}, \mathbf{i}}^{\prime} \eta+\epsilon
$$

where $\mathbf{Y}_{\mathbf{t}, \mathbf{i}}$ contains ex ante determinant variables of investment including investment opportunities $(Q)$, cash flow $(C F)$, governance variables, firm characteristics, deal purpose fixed effects, year fixed effects, and credit rating fixed effects.

All the determinant variables are calculated using data before loan initiation. Specifically, for governance variables, I include institutional ownership (INSTHOLD); analysts following ( $A N A L Y F)$; Gompers' gscore (INVGS for the original score multiplied by minus one and an indicator variable GSCORED equal to one for observations with a missing gscore); and CAPEX covenants (CAPEXREST). I also include eight firm characteristics: $\log$ of assets (LNASSET); investment through lease (LEASE); return on assets volatility (STDROA); standard deviation of investment (STDINVEST), Altman's zscore (ZSCORE), firm ages $(A G E)$, sales growth $(S A L E G)$, and debt over-

\footnotetext{
${ }^{34}$ If I use the raw $D C V$, the results are similar.
} 
hang correction $(R K)$. The standard errors are clustered by firm (Petersen 2008).

According to $\mathrm{H} 2 \mathrm{a}$ that $D C V$ reduces underinvestment, I expect $\delta_{1}>0$. Theoretically, under certain ideal conditions, only investment opportunities affect the optimal investment decisions (Hayashi 1982). Since Tobin's Q contains measurement errors, cash flow could partially capture investment opportunities (Alti 2003). I control for Tobin's $\mathrm{Q}$ and cash flow in all the specifications.

To test whether the effect of $D C V$ on investment is an increasing function of lenders' relative bargaining power (H2b), I add an interaction term to equation (3):

$I N V E S T=\gamma_{0}+\delta_{1} R E N E G D C V_{t, i}+\delta_{2} B A R G P O W * R E N E G D C V_{t, i}+\delta_{3} B A R G P O W+\mathbf{Y}_{\mathbf{t}, \mathbf{i}}^{\prime} \eta+\epsilon$

where BARGPOW is equal to INSTLP, FLENDER, KZIND, or TANG. I expect $\delta_{2}>0$.

\section{Empirical Results}

\subsection{Estimation of Debt-Contracting Value of Accounting Num- bers}

To estimate the debt-contracting value, I start with Compustat firms from 1990-2005. For each year starting from 1995, equation (1) is estimated by Fama-French industry (48 categories) using the past five years data. Table 3 tabulates the distribution of

coefficients in equation (1). The marginal effects of the explanatory variables on the predicted mean score are also provided. The predicted mean score is the sum of the ordered values minus one, weighted by the corresponding predicted probabilities for that observation. The Fama-MacBeth $t$-statistics suggest that all the lagged earnings 
and leverage ratios significantly explain the future credit ratings. Some lagged coverage ratios and net worth also explain borrower's future credit quality.

The ability of accounting numbers to predict future credit ratings could depend on the volatility of firms' fundamentals. I calculate the dispersion of cash flows, sales, and credit ratings for each Ordered Probit regression. The Spearman correlation between $D C V$ and the dispersion of sales is relatively high $(-0.29$ with $p$-value $<0.001)$, suggesting that more volatile fundamentals reduce the ability of the accounting system to predict future credit ratings. $D C V$ is also significantly correlated with the dispersion of credit ratings $(0.20$ with $p$-value $<0.001)$. I do not find a significant correlation between $D C V$ and the dispersion of cash flows. ${ }^{35}$

\subsection{Summary Statistics}

Table 4 presents descriptive statistics of the variables used in the cross-sectional analyses. All the continuous variables are winsorized at the top and bottom $1 \%$ level. The average quarterly investment INVEST between contract initiation and renegotiation/maturity is about $2 \%$ of total assets. The mean (median) firm in the sample has a $D C V$ of 0.572 (0.562). On a univariate basis, $D C V$ is negatively correlated with $R E N E G$ with a value of $-0.03(p=0.05)$, and positively correlated with INVEST with a value of 0.06 $(p<0.01)$. Debt overhang correction $(R K)$ is negatively and significantly correlated with INVEST, consistent with prior findings (Hennessy et al. 2007).

\footnotetext{
${ }^{35}$ The results of the following cross-sectional analyses are robust to controlling for the dispersion of sales and credit ratings
} 


\subsection{Ex Post Shocks, Debt-Contracting Value, and Renegotia- tion}

Although Table 2 shows that most renegotiation cases involve changes in accountingbased terms, it is still unclear whether they are due to the inability of accounting numbers to reflect ex post shocks. I combine the borrower, loan origination, and renegotiation data to form an unbalanced loan-quarter panel data set consisting of 19,282 loan-quarter observations. The first observation for each loan corresponds to the quarter of origination, and the last observation corresponds to the ultimate outcome of the loan (it matures, is renegotiated, or the borrower stops filing with the SEC). $D C V$ is calculated before loan initiation, while shocks are measured as the absolute value of changes in the default distance using Hillegeist et al.'s (2004) market-based measure $(D D)$ in quarter $q+1$ for any particular quarter $q$ relative to the quarter prior to origination (quarter 1). ${ }^{36}$ Negative (positive) shocks mean negative (positive) changes in $D D$. I partition $D C V$ and shocks into values above and below the median. For each loan-quarter, I create an indicator variable $R E N E G Q$, which equals one if there is any renegotiation during that loan-quarter.

In Table 5 Panel A, I split the sample above and below medians of $D C V$ and the magnitude of the shocks. The mean of RENEGQ is compared across the subgroups. For the full sample, when the shock is high, the group with high $D C V$ has a $12.1 \%$ probability of renegotiation, which is significantly less than that of the group with low $D C V(14 \%)$. The difference $(1.8 \%)$ is economically significant relative to the unconditional mean of RENEGQ (12.3\%). Such a relation does not hold when the shock is low.

\footnotetext{
${ }^{36}$ Specifically, Hillegeist et al. (2004) estimate the default distance based on Black-Scholes-Merton option-pricing model at firm-year level. I compute this measure at firm-quarter level by replacing their yearly variables with quarterly variables (i.e., equity volatility, risk-free rate, market value, long-term debt, and dividend yield.) Since $68 \%$ of loan-quarter observations do not have changes in credit ratings, I choose not to use credit ratings.
} 
In particular, the difference is only $0.4 \%$ and is statistically insignificant. Similarly, the group with high shocks has a higher probability of renegotiation than the group with low shocks, and the difference is significant only when $D C V$ is low. Partitioning the sample by the nature of the shock (i.e., positive or negative changes) does not change the results in Panels B and C. ${ }^{37}$

This pattern sheds some light on the mechanism through which $D C V$ affects renegotiation. In the next subsection, I do not include ex post shocks to explain the incidence of renegotiation, because the purpose of the analyses is to identify determinant variables before firms make any investment decisions and not to maximize explanatory power.

\subsection{Ex Ante Determinants of Probability of Renegotiation}

Table 6 reports the marginal effects for my Probit analysis of hypothesis H1. I first estimate the model using the full sample and then delete renegotiations not involving changes in accounting-based contractual terms. In columns (1) and (4), only firm characteristics are included. Columns (2) and (5) use all the control variables following the specification of Roberts and Sufi (2009a). I add more relevant control variables in columns (3) and (6).

I find evidence that $D C V$ is negatively associated with the likelihood of ex post renegotiation; that is, the estimated coefficients on $D C V$ are negative and statistically significant. The $t$-statistics range from 1.67 to 2.93. In terms of the economic signifi-

\footnotetext{
${ }^{37}$ Here is an example of how the inability of accounting numbers to reflect good news triggers renegotiation. Warnaco is a textile/apparel corporation. Its products are sold under several brand names including Calvin Klein, Speedo, Chaps, etc. In 2005, Warnaco's net revenues rose by $5.6 \%$ to 1.5 billion and net income increased $22 \%$ to 52.1 million. However, not fully incorporating this good news, a debt-to-earnings-based performance pricing provision still provided an undesired interest rate. Warnaco renegotiated with the lender, Citigroup, and successfully reduced the interest rate. In the same amendment file, a fixed charge coverage ratio covenant was tightened. Dichev et al. (2002) show that performance pricing provisions are typically designed to handle credit improvements. This case suggests that a lower quality of variables used in these provisions could trigger renegotiation.
} 
cance, the marginal effect of $D C V$ is -0.316 in column (2). In other words, a positive change in $D C V$ from the first quartile to the third quartile is associated with a change in the predicted probability of renegotiation equal to $4.6 \%$. Given that the mean probability of renegotiation equals $75.8 \%$, this effect represents a decrease of $6 \%$. These findings provide consistent support for $\mathrm{H} 1$.

Roberts and Sufi (2009a) do not find any significant coefficient on firm characteristics. In contrast, I observe in columns (1) and (4) that larger firms are less likely to renegotiate their private debt contract, which could be because my sample size is three times larger than theirs. Interestingly, the coefficients on $M T B$ are consistently negative and statistically significant. While firms with a high market-to-book ratio may be exposed to more shocks and therefore are more likely to renegotiate, the renegotiation cost for both parties to find a new and better contract could also be very high due to high uncertainty. The negative coefficients suggest that the second argument dominates.

In terms of loan characteristics, consistent with Roberts and Sufi (2009a), I find that loans with longer maturities, with accounting-based borrowing bases, and with income-statement-based covenants are more likely to be renegotiated. ${ }^{38}$ I have no direct predictions on other loan characteristics. On one hand, there is more to gain by amending a large lending deal, while on the other hand, the renegotiation may be more costly for both parties due to the complexity of the transaction. The results show that DAMOUNT loads positively, suggesting that the first argument dominates. In addition, $R E V L V$ and $P G$ load positively in all specifications. The coefficients on $B O W B A S E$ are positive and significant in columns (3)-(6). COVIS loads positively in columns (4)-(6). The results, similar to Roberts and Sufi's (2009a), suggest that the

\footnotetext{
${ }^{38}$ Roberts and Sufi (2009a) observe that over $90 \%$ of long-term debt contracts are renegotiated, suggesting little variation on RENEG for long-term contracts. After deleting contracts with a maturity period shorter than three years, I continue to find results supporting my main conclusion.
} 
presence of ex ante contingent contractual features (covenants, performance pricing, and borrowing bases) does not reduce renegotiation. It is possible that ex ante contingencies are put into contracts that are more likely to be renegotiated. If these contractual features are used to reduce renegotiation and, therefore, are more frequently included in contracts where renegotiation is more likely, then my parameter estimate will be biased upwards. In other words, renegotiation would have been even more likely had the contingent features not been incorporated into the contract, all else being equal.

As for additional control variables, I do not find significant coefficients on $C O V B S$. This finding, combined with the positive loadings of COVIS in columns (5) and (6), is consistent with Christensen and Nikolaev (2011). ${ }^{39}$ The results on $D C V$ continue to support my main conclusion after including all the control variables.

\subsection{Impact of Debt-Contracting Value on Investment}

Table 7 provides evidence on underinvestment. Panel A columns (1) and (2) present the mean and median of abnormal investment. The abnormal investment is the difference between actual investment and the predicted investment by Tobin's $Q$ and cash flow CF. My sample firms underinvest on average 0.00591 or $30 \%$ relative to the mean of INVEST (0.020).

Columns (3)-(6) present the distribution of matched-pair investment differences. The sample firms invest less relative to themselves in the same period of the previous year, and relative to peers matched by year, industry, and sales growth. Nini et al. (2009a) find that capital expenditure covenants effectively reduce the $C A P E X$ investment level.

\footnotetext{
${ }^{39}$ Christensen and Nikolaev (2011) argue that income-statement-based covenants ("performance covenants" in their paper) and balance-sheet-based covenants ("capital covenants" in their paper) improve contracting efficiency through different mechanisms. They further predict and find that the number of income-statement-based covenants is positively related to the frequency of contract renegotiations that waive or reset covenants, and that the number of covenants on balance sheet items does not affect the likelihood of renegotiations.
} 
Bearing that in mind, I delete sample firms that have $C A P E X$ covenants. The magnitude of underinvestment in Panel B is smaller, consistent with Nini et al. (2009a), but I keep observing both statistical and economic significance for underinvestment.

Since the negative differences could also imply overinvestment for benchmark groups, I choose to only use the sample firms. Panel C presents the implication of INVEST on $R O A$ in the next one, two, and three years. I control for $Q, C F, S T D R O A, L N A S S E T$, and past $R O A$ averages over the same horizon as the dependent variables (LAGROA), industry fixed effects, and year fixed effects. The positive coefficients of INVEST suggest that a positive shift of investment increases the future rate of return, consistent with the underinvestment story.

Table 8 columns (1) and (2) report the results for my tests of H2a. I find evidence that RENEGDCV is positively associated with the INVEST. The $t$-statistics are 2.44 and 1.82. In terms of economic significance, taking column (2), for example, given the impact of $D C V$ on the probability of renegotiation (4.6\%), increasing $D C V$ from the first quartile to the third quartile increases the investment (or improves the underinvestment) by approximately 0.0013 , or $22 \%$ relative to 0.00591 in Table 7 Panel A column (1). I control for the potential omitted correlated variable $L E A S E$, which is the estimated investment through leasing, because Beatty et al. (2010b) find that poor accounting quality firms tend to lease rather than buy their assets. The results are robust to that control. Consistent with the findings in Nini et al. (2009a) and Chava and Roberts (2008), the covenants of capital expenditure (CAPEXREST) significantly reduce the level of investment.

Table 8 columns (3) to (6) present the results after adding the interaction terms between RENEGDCV and the proxies for lenders' relative bargaining power ( INSTLP, FLENDER, KZIND, and TANG). The interaction terms are significant for all cases, 
and the signs are consistent with my predictions. The results in general are consistent with $\mathrm{H} 2 \mathrm{~b}$ that the impact of the debt-contracting value of accounting on investment increases with lenders' relative bargaining power.

\section{Additional Analyses}

At this point, I conclude that firms with a higher debt-contracting value of accounting are less likely to renegotiate their private debt contracts and have less underinvestment. The impact of the debt-contracting value of accounting on investment increases with lenders' relative bargaining power. In this section, I further examine the robustness of my results.

\subsection{Alternative Debt-Contracting Value Measures}

Original Debt-Contracting Value: I calculate Ball et al.'s (2008) original debtcontracting value $(D C V O)$, which is measured as Somers' D, a goodness-of-fit statistic, from the following Probit regression for each 2-digit SIC industry group with at least 20 firms: ${ }^{40}$

$$
P\left(\text { Downgrade }_{t, i}=1\right)=f\left(\alpha_{0}+\alpha_{1} \Delta E_{t-1, i}+\alpha_{2} \Delta E_{t-2, i}+\alpha_{3} \Delta E_{t-3, i}+\alpha_{4} \Delta E_{t-4, i}\right)
$$

where Downgrade $_{t, i}$ is an indicator variable equal to one if firm $i$ 's credit rating is downgraded in the current quarter $t$ (equal to 0 otherwise), and $\Delta E_{t-k, i}$ is the seasonally adjusted change in quarterly earnings before extraordinary items scaled by total assets

\footnotetext{
${ }^{40}$ Ball et al. (2008) also estimate another measure by adding five additional variables: change in sales, change in sales of the largest business segment, change in the number of business segments, change in cash from operations divided by total debt, and change in leverage. Among them, the last two variables are often used in accounting-based contracting terms. Including all these five variables or just the last two variables in the estimation of $D C V O$ does not change the results.
} 
in the $k^{\text {th }}$ quarter prior to the current quarter $t$. Table 9 column (1) shows that using this measure does not change my inferences. ${ }^{41}$

Firm-Specific Debt-Contracting Value: After each Ordered Probit estimation of equation (1), I calculate the predicted mean score, which is the sum of the ordered values minus one, weighted by the corresponding predicted probabilities for that observation. The absolute value of the difference between the observed ratings and the predicted mean score captures how well accounting numbers capture future credit quality. The Firm-Specific debt-contracting value $(D C V F)$ is the average of the absolute value over the past five years. This new measure reduces the sample to 1,723 observations, but I continue to find a significant negative relation between the debt-contracting value and the incidence of renegotiation in Table 9 column (2).

Accounting Quality: I also adopt the measure of accounting quality $(A Q)$ estimated from the Modified Dechow-Dichev model (McNichols 2002; Francis et al. 2005). I estimate the following equation for each of Fama and French's (1997) 48 industry groups with at least 20 firms in year $t$ :

$$
T C A_{j, t}=\phi_{0}+\phi_{1} C F O_{j, t-1}+\phi_{2} C F O_{j, t}+\phi_{3} C F O_{j, t+1}+\phi_{4} \Delta R e v_{j, t}+\phi_{5} P P E_{j, t}+v_{j, t} .
$$

$A Q$ is calculated as the standard deviation of firm $j$ 's residuals, $v_{j, t}$ over years $t-4$ through $t$. This measure is a firm-level measure, capturing how well accounting numbers map into the past, current, and future realized operating cash flows. $A Q$ loads negatively in Table 9 column (3). ${ }^{42}$ I further decompose the accounting quality measure into innate

\footnotetext{
${ }^{41}$ In their footnote 18, Ball et al. (2008) indicate that including upgrades in the estimation of DCVO does not change their inference. My results are also robust to this specification.

${ }^{42}$ Conditional accounting conservatism is another important accounting attribute in debt contracting. I do not choose it to measure $D C V$ for three reasons. First, all the Basu-type conservatism measures in the literature use news in current stock returns or current cash flows as a benchmark to see how well accounting numbers reflect bad news relative to good news. However, evidence shows that lenders and borrowers have more private information about future conditions beyond current stock prices
} 
and discretionary parts by regressing $A Q$ on firm size, standard deviation of operating cash flow, standard deviation of sales, length of operating cycle and incidence of negative earnings (Francis, et al. 2005). Both parts load negatively in explaning the probability of renegotiation.

\subsection{Additional Analyses on Renegotiation}

Intensity of Renegotiation Related to Accounting Numbers: Debt renegotiation can be triggered by many factors other than issues concerning accounting numbers. Table 2 shows that there are $25 \%$ of cases without changes in accounting-based contractual terms. In addition, the binary variable $(R E N E G)$ cannot capture the intensity of renegotiation related to accounting issues. As a result, I first create an indicator variable for each change of covenant in Table 2 Panel B, change of accounting-based performance pricing, and change of accounting-based borrowing base in Table 2 Panel A. The intensity is calculated by summing up all the indicators for each renegotiation. I then estimate a negative binomial model of this new variable on all the factors in Table 5. The total number of financial covenants $(F C O V N U M)$ is also included. Table 10 column (1) shows that firms with higher $D C V$ are less likely to have renegotiations

(Massoud et al. 2010; Ivashina and Sun 2010; Bushman et al. 2010; Chen and Martin 2011). Second, conditional conservatism measures the asymmetric timeliness of accounting numbers, in other words, the timeliness of bad news relative to good news. Despite the fact that after signing the contract bad news is more relevant to lenders due to the asymmetric payoff structure, given that ex ante the project financed by debt has positive NPV, it is unclear whether more timeliness of bad news is preferable for both parties (Gigler et al. 2009; Lambert 2010). Third, a high level of conditional conservatism may help reflect bad economic conditions, but it may also trigger false alarms (Gigler et al. 2009). This argument is not inconsistent with prior findings. Zhang (2008) adopts an ex post setting to explore the usefulness of conditional conservatism in debt contracting. Specifically, she starts with sample firms with at least one monthly return less than -30\% during 1999 and 2000. In her setting, given that large negative shocks occur, covenant violations accelerated by conservative reporting are less likely to be false alarms. Despite these caveats, I put two measures of conditional conservatism into my Probit analyses separately: a time-series estimated Basu measure (Francis et al. 2004) and the Cscore (Khan and Watts 2009). The coefficient of Basu measure is negative but not significant, whereas the coefficient of Cscore is insignificantly positive. Thus the impact of conditional conservatism on renegotiation is still inconclusive. 
involving changes in accounting-based contractual terms.

Accounting Adjustment in Original Contracts: Li $(2010,2011)$ shows that the contracts in my sample use adjusted accounting numbers, which are systematically different from GAAP. The adjustments have been taken into account in calculating $D C V$ to some extent. To further rule out the possibility that some special contractual adjustments drive the main results, I focus on a subsample where the contractual definition of earnings is exactly the same as the definition of earnings used in calculating $D C V$. Specifically, using the data from Li (2011), I identify contracts with debt-to-earnings covenants (DCF sample hereafter). Li (2011) finds that $96.4 \%$ of the contracts in the DCF sample exclude depreciation and amortization (long-term accruals). Within these contracts, I further require that there are no other adjustments such as excluding noncash expense, non-cash income, etc., yielding 1,058 observations. ${ }^{43}$ I then estimate a Probit model. The dependent variable is an indicator that captures whether the debtto-earnings covenant is amended or not. The explanatory variables include $D C V$ and other factors in Table 6. The results are tabulated in Table 10 column (2). No inferences are affected.

Covenant Tightness: Dichev and Skinner (2002) propose a "trip wire" theory of financial covenants. According to this theory, initial covenants are intentionally set tight so that triggering covenants rings the bell for lenders monitoring, and borrowers renegotiate down the covenants restriction after each violation. Table 5 shows that not only negative shocks, but also positive shocks, trigger renegotiation. ${ }^{44}$ To further explore

\footnotetext{
${ }^{43} \mathrm{Li}$ (2011) focuses on three samples: contracts with debt-to-earnings covenants, contracts with interest coverage covenants, and contracts with fixed charge coverage covenants. I do not use the other two samples because of the small sample sizes (267 and 519 observations, respectively) after my requirement.

${ }^{44}$ In Appendix III Example 4, Warnaco Inc requests and obtains lower interest rates and tighter fixed charge coverage covenants (untabulated) in the renegotiation, which is very likely to be triggered by positive shocks.
} 
this issue, I add the number of financial covenants (FCOVNUM) as a proxy for initial tightness in the regressions of Table 6. The coefficient of FCOVNUM is significantly positive (z-stats=2.46), supporting the "trip wire" argument. More importantly, the inference on $D C V$ is unchanged.

Operation Complexity: Segal (1999) suggests that operation complexity is one of the major reasons for contract incompleteness. Facing a complex world, contracting parties may find it efficient to leave some scope for renegotiation in the future. In Table 6, I control for firm size, market-to-book ratio, and the standard deviation of ROA. To further explore the possibility of complexity as a reason for renegotiation, I add two more control variables: the number of business segments and the number of geographic segments. The inference is not affected.

Mandatory GAAP Changes: If a contract uses rolling GAAP as a starting point to define the contractual accounting numbers, then mandatory accounting changes might create incentives for renegotiation to shield the impact of the changes. In addition, Christensen and Nicoleav (2010) identify a new contracting practice that gives the contracting parties an option to exclude the effect of accounting changes (mutual-option-to-freeze GAAP). I randomly pick 100 contracts to read the definition of GAAP in detail, and find that $37 \%, 30 \%$, and $33 \%$ of them use rolling, frozen, and mutual-option-to-freeze GAAP respectively. The t-tests across any two groups about $R E N E G$ are never significant, suggesting that the GAAP rules chosen in the initial contracts do not play a significant role in ex post renegotiation. However, these results should be interpreted with caution due to the small sample size.

Redacted Disclosure: Despite the strict requirement of Regulation S-K, there are some exemptions. Verrecchia and Weber (2006) find that the SEC allows firms to request that the proprietary information contained within the contract be withheld, if 
it "covers trade secrets and commercial or financial information obtained from a person and privileged or confidential information." Therefore, the contracts identified as nonrenegotiation could be due to the borrowing firms filing the amendment privately with the SEC. Following Verrecchia and Weber (2006), I search the exhibit lists of my sample firms' $10-\mathrm{K}$ forms using the phrase "confidential treatment" between the debt initiation date and maturity date. I create an indicator variable equal to one if there is any confidential treatment during that period. I find that the contracts with renegotiation are even more likely to have redacted disclosure (21\%) than without renegotiation (19\%) (t-stats=1.60). This finding suggests that non-renegotiation cannot be explained by redacted disclosure. The bias, if any, is against my findings.

Replacing Original Contracts: Among 2,819 cases of renegotiation, there are 372 cases of actually initiating a new loan right before maturity to replace the prior one. For example, Alcoa Inc and J.P. Morgan had a loan with a maturity date of April 26, 2003. They initiated a new loan starting on April 25, 2003 to repay the old one. Obviously, replacing original contracts are not driven by accounting issues. Therefore, I conduct two analyses. First, I exclude the replacing cases and rerun the Probit regression. All the results still hold. Second, I only keep the replacing cases and non-renegotiation cases, and rerun the tests. $D C V$ loses significance, consistent with my expectation.

Mergers and Acquisitions: I check whether there are more M\&A activities in the window between loan initiation and renegotiation than in the window with the same length preceding loan initiation. Specifically, I create an indicator variable equal to one if the firm engages in a merger and acquisition as per the SDC Platinum M\&A database, and zero otherwise. I do not find a significant difference between these two windows.

Control for Endogeneity: I acknowledge that it is challenging to establish causality between the debt-contracting value of accounting and the likelihood of renegotiation. 
However, I have implemented research design features to at least partially alleviate such concerns. First, and perhaps most important, economic theory supports my finding that $D C V$ has a negative effect on the probability of renegotiation. Second, I test the effect of $D C V$ before signing the contract on the likelihood of renegotiation after signing the contract. Third, I include control variables motivated by prior research. Furthermore, I introduce a number of additional controls. As a final control for endogeneity, I consider a simultaneous equations model estimated by the maximum likelihood method. To model cross-sectional variation in $D C V$, I include all control variables from Table 6 column (3), and add a variable that reflects the strength of the relation between the firm and suppliers. Extant research (e.g., Bowen et al. 1995; Raman and Shahrur 2008; Dou et al. 2011) shows that a firm's suppliers affect the firm's financial reporting quality. The instrument $(S R D)$ is constructed as suppliers' R\&D investment intensity following Raman and Shahrur (2008). SRD is significantly correlated with $D C V$ but is not significantly correlated with the incidence of renegotiation. The results in Table 10 columns (3) and (4) show that no inferences are affected after controlling for potential endogeneity of $D C V$ through this simultaneous equation estimation.

\subsection{Additional Analyses on Investment}

Investment Opportunities: It has been shown that the average $Q$ used in my regression models is a very noisy measure of true investment opportunities (Cummins et al. 2006). Therefore the relation between $D C V$ and investment could be attributed to a component of $D C V$ related to investment opportunities. Following Cummins et al. (2006), I use analysts' earnings forecasts to calculate the expected market value (i.e., intrinsic value following Frankel and Lee (1998)) as the numerator of $Q$. Using this new $Q$ does not change my results in Table 8 . 
The Debt-Contracting Value and Information Monopoly: Incumbent creditors' information monopolistic position could be further enhanced when outside creditors cannot learn about the borrower from its accounting numbers. Therefore, the bargaining power of inside lenders might well be reduced by borrowers' higher $D C V$, increasing the ex ante incentive of investment as a result. However, this explanation cannot generate the interaction effect from H2b. Nevertheless, if higher $D C V$ can unwind the information monopoly to some extent, one should observe that firms with higher $D C V$ are more likely to obtain borrower favorable renegotiation outcomes. Following Massoud et al. (2010), I define borrower favorable loan amendments as those amendments with at least one favorable loan contract term change, but with no unfavorable loan contract term changes, entailing a smaller principal, a higher interest rate or a shorter maturity. A value of one is assigned to borrower favorable outcomes and zero otherwise. I estimate a Probit model of the renegotiation outcomes on $D C V$ controlling for all the factors in Table 6. The coefficient of $D C V$ is negative and insignificant, suggesting that there is another channel of communication between borrowers and outside lenders. At the same time, this channel is not fully effective, yielding the hold-up problem. The interpretation should be cautious because of the difficulty of determining whether renegotiation is borrower favorable, even in simple cases (consider the tightening of a financial covenant coupled with a decrease in interest).

Growth Opportunities: When calculating the measure of investment, I include both capital expenditures and R\&D. Smith and Watts (1992) and Skinner (1993) argue that accounting numbers are poorer performance measures for firms with relatively more growth opportunities because of the need for objective and verifiable numbers for recognition. Specifically, R\&D is one of the proxies for growth opportunities in Skinner (1993). The relation between my $D C V$ variables and investment, including R\&D, could 
be driven by this growth-opportunities argument. I exclude R\&D expense from my investment measure, and then rerun all the tests related to investment. The results are similar.

\subsection{Survival Analysis}

Survival analysis explores the duration between loan initiation and renegotiation. If greater $D C V$ helps to incorporate news about future credit quality, I predict that it should delay renegotiation of the original agreements. To test this prediction, I adopt the Cox proportional hazard model: $:^{45}$

$$
h_{i}(t)=\frac{f_{i}(t)}{1-F_{i}(t)}=h_{0}(t) \exp \left(\beta_{1} D C V_{t, i}+\mathbf{X}_{\mathbf{t}, \mathbf{i}}^{\prime} \zeta\right)
$$

where $h_{i}(t)$ represents the instantaneous risk of renegotiation at time $t$ for debt $i$ conditional on $i$ surviving to time $t$, and $h_{0}(t)$ is the baseline hazard rate. The term $\mathbf{X}_{\mathbf{t}, \mathbf{i}}$ includes all the factors in Table 6 . Let $d_{i}=1$ if debt $i$ does not mature and the borrower does not stop filing (i.e., uncensored), and $d_{i}=0$ otherwise (right-censored). The likelihood function is

$$
L(\theta)=\sum_{i=1}^{n} d_{i} \ln f_{i}(t)+\sum_{i=1}^{n}\left(1-d_{i}\right) \ln \left(1-F_{i}(t)\right) .
$$

Note that the second part on the right-hand side is used to correct right-censoring. The estimated coefficients as well as $z$-statistics from the robust standard errors (Lin and Wei 1989) are presented in column (5) of Table 10. As expected, the coefficient on $D C V$ is significantly negative, indicating that the hazard ratio (renegotiation conditional on

\footnotetext{
${ }^{45}$ See Kiefer (1988) for basic background. See Beatty et al. (2002) and Zhang (2008) for applications in accounting research.
} 
surviving) is reduced by higher $D C V$ even after controlling for other determinants. Put another way, the length of time that elapses between debt initiation and renegotiation is longer for borrowers with higher $D C V$.

\section{Voluntary Disclosure, Renegotiation, and Infor- mation Monopoly}

One important source of lenders' relative bargaining power is based on Rajan's (1992) information monopoly theory. The thrust of Rajan's argument relies on the information asymmetry between inside banks and outside banks about the quality of borrowers. He further argues that the "soft" unverifiable information obtained by insiders cannot be credibly communicated to outsiders by borrowers. Nevertheless, Farrel and Gibbons (1989) and Gigler (1994) demonstrate that unverifiable information, which cannot be conveyed privately to any outsiders, can be credibly communicated publicly, because the costs of disclosing proprietary information can make such disclosures credible.

Using two public disclosure practices, management forecasts and conference calls, I examine whether firms provide more voluntary disclosure between loan initiation and renegotiation, and whether more voluntary disclosure could induce more favorable renegotiation outcomes for the borrowers. The data on management forecasts and conference calls are obtained from First Call and Best Call, respectively. I choose the period between loan initiation and renegotiation as the treatment window. A separate period with the same length as the treatment window preceding the initiation date is used as a control window. 


\subsection{Do Borrowers Disclose More before Renegotiation?}

I first create an indicator variable $M F$ that takes the value of 1 if any management forecast is issued. I also count the number of guidance events in each window and use the log of one plus the number of forecasts issued (LOGNMF). My third and fourth measures are based on Chen et al. (2008). In particular, following Chen et al. (2008), I compute cumulative abnormal returns centered on the forecast date, and define positive (negative) abnormal returns as good (bad) news. The second and third measures are the $\log$ of one plus the number of good news (LOGNGMF) and bad news (LOGNBMF) forecasts, respectively. My fifth metric is a measure of the quality of management guidance based on the Francis et al. (2008) management forecast score. This score measures how specific the forecasts are. It is equal to 1 for qualitative guidance (e.g., earnings outlook improved), 2 for open-ended guidance (e.g., earnings should exceed the prior period), 3 for range guidance (e.g., earnings fall between $\mathrm{x}$ and $\mathrm{y}$ ), and 4 for point guidance (e.g., an actual earnings estimate). Following Francis et al. (2008), I then take the log of one plus the sum of scores for each firm (LOGMFS). I use both quarterly and annual management earnings guidance to construct guidance measures. Finally, I use an indicator variable $(C C)$ that equals 1 if any conference call occurs and the $\log$ of one plus the number of conference calls $(L O G N C O N F C)$. I calculate these seven variables in each window and then take the differences between two windows. The differences capture whether borrowing firms increase disclosure.

The change of disclosure is a function of changing underlying economic conditions. I choose both firm-specific and macroeconomic factors as control variables. The firmspecific variables are selected at the end of each window including leverage $(L E V)$,

market to book ratio $(M T B)$, and return on assets $(R O A)$. I then take the difference of all the variables between treatment and control windows, and regress the changes of 
disclosure intensity on an intercept $(P O S T=1)$ with the changes of control variables. I also include cumulative stock returns between loan origination and renegotiation $(R E T)$. Two macro-economic variables, credit spread (CASPREAD) defined as the yield on BB-rated bonds minus the yield on AAA-rated bonds and the return on CRSP valueweighted index ( $V W R E T)$, are also added into the regression. Finally, I control for all the firm characteristics and deal characteristics in equation (2). The intercept captures the mean incentive effect to undo the hold-up by inside banks. Table 11 shows that borrowing firms issue more management forecasts and hold more conference calls in the treatment window than in the control window, except for management forecasts with bad news. This is consistent with the intuition that firms with bad news do not have the incentive to reveal their type. The next subsection examines whether more disclosures indeed lead to better renegotiation outcomes.

\subsection{Do More Disclosures Lead to Better Renegotiation Out- comes?}

For the 2,819 renegotiation cases, I code the renegotiation outcomes in the same way as in section 6.3. Specifically, I define borrower favourable loan amendments as those with at least one favorable loan contract term change, but with no unfavorable loan contract term changes, entailing a smaller principal, a higher interest rate, or a shorter maturity. A value of one is assigned to borrower favourable outcomes and zero otherwise.

I estimate a Probit model to explore whether the change of my disclosure variables affect the renegotiation outcomes, controlling for the changing in underlying economic conditions, firm characteristics at origination, deal characteristics, industry fixed effects, deal purpose fixed effects, and year fixed effects. Table 12 shows that more management forecasts with good news increase the likelihood of obtaining better renegotiation 
outcomes for borrowers.

In summary, I find that firms indeed issue more management forecasts and hold more conference calls in the treatment window than in the control window, and that these results are robust to controlling for the changes in leverage, market-to-book ratio, return on assets, credit spreads, and market returns. I further find that with the exception of management forecasts with good news, all the other formats of disclosure cannot help borrowers to obtain better contracting terms in renegotiation. Even for management forecasts with good news, the statistical significance is marginal $(z$-value $=1.74)$. This suggests that firms cannot expect to eliminate lenders' bargaining power through management forecasts and conference calls, in order to solve the hold-up problem. However, the results should be interpreted with caution due to the difficulty of determining whether renegotiation is borrower favorable.

\section{Concluding Remarks}

Accounting numbers are broadly used in debt contracting to incorporate news and hence facilitate the lending process. This thesis focuses on the contracting role of accounting numbers, and on the real effects of accounting on corporate investment. Specifically, I investigate the impact of the debt-contracting value of accounting numbers on the likelihood of ex post private debt renegotiation, and the implication of renegotiation for investment efficiency. The extent to which accounting numbers reflect the shocks about future states determines the size of gains from renegotiation. When the gains are large enough, both parties have incentives to renegotiate a new contract. Moreover, during the renegotiation, lenders can extract benefit from borrowers' investment. As such, a higher anticipated probability of renegotiation reduces the ex ante investment incentives of borrowers and leads to the underinvestment problem. 
Tracking 3,720 private debt contracts, I find that $76 \%$ of the contracts are renegotiated before maturity, and that $75 \%$ of these renegotiation cases are related to changes of accounting-based contractual terms. I further find that firms with a higher debtcontracting value of accounting have a lower probability of renegotiation, and less underinvestment. Moreover, the effect of the debt-contracting value of accounting on investment increases when lenders have more relative bargaining power. Additional evidence suggests that management forecasts and conference calls cannot eliminate lenders' bargaining power derived from the information monopoly problem. By exploring the role of accounting numbers in private debt agreement renegotiation, this thesis identifies a specific channel through which a better quality of accounting numbers (i.e.,a higher debt-contracting value of accounting) improves contract completeness and thus investment efficiency. 


\section{Appendix I: A Stylized Simple Model Relating to H1 and $\mathrm{H} 2$}

This model is a simplified version of Rajan (1992) augmented with a financial covenant. In Rajan (1992), there is no state-contingent contractible variable (accounting number), and therefore he only examines two extreme cases: (1) long-term contract, where there is absolutely no renegotiation; (2) short-term contract, where there must be a renegotiation to renew the contract during interim. By incorporating a financial covenant, this simple model fits in between and could generate the implication of $D C V$ on both renegotiation and investment. Gigler et al. (2009) propose a similar model, but without a private signal and both parties learn about future cash flows from an accounting signal. Therefore there exists no renegotiation opportunities. My model also shares some similarities with Aghion and Bolton (1992) in that both parties have an incentive to renegotiate a new contract when new information comes in and the contracted variable is imperfect. However, they do not examine how the quality of the contracted variable affects renegotiation and investment, which is the focus of this model.

Consider a two-period game. At date 0 a firm signs a loan contract with a bank, and invests the borrowed amount $K$ into a project A. At date 1 if the project is liquidated, it produces a deterministic liquidation value of $M$; if the project is continued, it produces an uncertain cash flow $x$ ( $x_{H}$ or $x_{L}$ with an equal probability ex ante). Assume the risk-free rate is 1 , and $x_{H}>\frac{x_{H}+x_{L}}{2}>K>M>x_{L}$. Prior to making the liquidation/continue decision at date 1 , an accounting signal $y$ that reveals noisy information about $x$ is received by both parties. Assume $y$ equals $y_{H}$ or $y_{L}$ with an equal probability ex ante. Between date 0 and 1 , both lenders and borrowers observe a binary private signal $s$ about $x$. Suppose $s$ is correlated with

$x$ (i.e.Prob $\left(x_{H} \mid s_{H}\right)=\operatorname{Prob}\left(x_{L} \mid s_{L}\right)=\rho$ where $\left.\frac{1}{2}<\rho<1\right)$, but not contractible. Although $y$ is contractible and related to $s\left(\operatorname{Prob}\left(y_{H} \mid s_{H}\right)=\operatorname{Prob}\left(y_{L} \mid s_{L}\right)=\gamma\right.$ where $\left.\frac{1}{2}<\gamma<1\right)$, it cannot provide additional information about $x$ beyond $s$ (i.e., $\operatorname{Prob}\left(x_{H} \mid s_{H}, y_{i}\right)=\operatorname{Prob}\left(x_{L} \mid s_{L}, y_{i}\right)=\rho$ where $i \in H, L)$. Following the Bayesian rule, $\operatorname{Prob}\left(x_{H} \mid y_{H}\right)=\operatorname{Prob}\left(x_{L} \mid y_{L}\right)=\gamma \rho+(1-\gamma)(1-$ 
$\rho)=1-\rho+\gamma(2 \rho-1)$. Given the information content of the private signal $\rho$, the parameter

$\gamma$ captures the debt-contracting value of accounting-the correlation between the contracted accounting signal and the future credit quality.

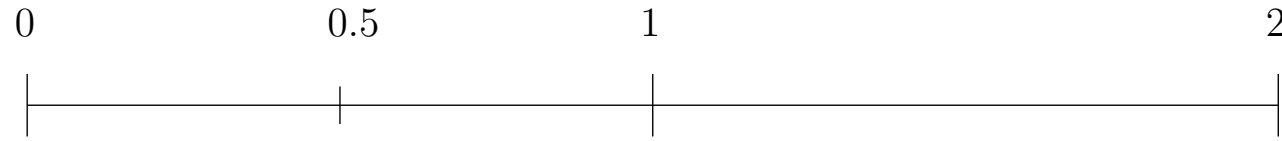

$\begin{array}{llll}\text { Contract } & \text { Private signal } s . & \text { Accounting signal } y . & \text { Cash flow } x \text { realizes } \\ \text { signed } & \text { Contract may be } & \text { Liquidate or continue } & \text { The firm pays } \\ \text { with terms } & \text { renegotiated } & \text { according to the contract } & \text { or becomes bankrupt } \\ \left\{D, y^{c}\right\} & \text { as }\left\{\hat{D}, \hat{y}^{c}\right\} & & \end{array}$

Figure 1: Time Line of Events in Each Period

At date 0 , the contract is signed as $\left\{D, y^{c}\right\} . D$ is the chosen face value of the debt, so that if the project is continued, at date 2 the lender receives the amount $D$ if $x_{H}$ is realized $\left(x_{H}>D\right)$, or $x_{L}$ if $x_{L}$ is realized $\left(D>x_{L}\right)$. In any equilibrium, $D$ cannot be less than $M$, otherwise, the lenders and borrowers would not sign the contract ex ante. $y^{c}$ is the covenant provision that the project is continued as long as $y>y^{c}$. Since $y$ is a binary variable, $y^{c} \in\left\{y_{L}, y_{H}\right\} .{ }^{46}$ At date 0.5 , after receiving the new information $s$, the firm and bank can renegotiate a new contract $\left\{\hat{D}, \hat{y}^{c}\right\}$ and undertake the renegotiation cost $c$. Assume $0<c<M-(1-\rho) x_{H}-\rho x_{L}<\rho x_{H}+(1-\rho) x_{L}-M{ }^{47}$

Proposition 1 If $\gamma \geq 1-\frac{c}{(2 \rho-1)\left(x_{H}-x_{L}\right)}$ then $y^{c *}=y_{L}$ and Prob(Renegotiation $)=0$; If $\gamma<1-\frac{c}{(2 \rho-1)\left(x_{H}-x_{L}\right)}$ then $y^{c *}=y_{H}$ and $\operatorname{Prob}($ Renegotiation $)=\frac{1}{2}$.

Proposition 1 corresponds to my H1. It shows that even if the initial contracting terms are endogenously determined, the effect of $D C V$ on the probability of renegotiation still holds. ${ }^{48}$

Suppose the firm has another independent project B with investment $I$ at date 0 after

\footnotetext{
${ }^{46} y^{c}=y_{H}$ indicates a very restrictive covenant, meaning that the covenant will be violated with a probability of 1 , whereas $y^{c}=y_{L}$ indicates that the covenant is violated only when $y=y_{L}$.

${ }^{47}$ If the renegotiation cost is prohibitive, then the renegotiation will never happen as a bond contract and the problem becomes trivial.

${ }^{48}$ The intuition of this result is similar to Gigler et al. (2009), who demonstrate that the optimal adjustment in the initial covenant to offset the conservative accounting signal is always incomplete.
} 
signing the debt contract, and returns $r(I)$ at date 2 or 0 if project $\mathrm{A}$ is liquidated, ${ }^{49}$ where $r($.$) is a concave function. Let r(I)+x_{L}<M$; otherwise, the bank and firm will always continue project $\mathrm{A}$. Then the first best investment level for project $\mathrm{B}$ is $r^{\prime}\left(I^{F B}\right)=1$, and the second best investment level in the sense of Myers (1977) is $r^{\prime}\left(I^{S B}\right)=2$ due to the half probability of liquidation ex ante. Since $r\left(\right.$.) is a concave function, $I^{S B}<I^{F B}$. Assume that bargaining power is allocated as $1-\beta$ for the bank and $\beta$ for the firm.

\section{Proposition 2}

a. If $\gamma \geq 1-\frac{c}{(2 \rho-1)\left(x_{H}-x_{L}\right)}$ then $y^{c *}=y_{L}$ and $I^{*}=I^{S B}$; If $\gamma<1-\frac{c}{(2 \rho-1)\left(x_{H}-x_{L}\right)}$ then $y^{c *}=y_{H}$ and $I^{*}<I^{S B}$.

b. $\frac{\partial\left(I^{S B}-I^{*}\right)}{\partial \beta}<0$.

Propositions $2 \mathrm{a}$ and $2 \mathrm{~b}$ correspond to my $\mathrm{H} 2 a$, and $\mathrm{H} 2 b$ that the underinvestment problem is mitigated by a higher $D C V$ and that such mitigation is stronger when the borrowing firm has less bargaining power.

Proof of Proposition 1: Using backward induction, I first examine the renegotiation decision at date 0.5 after receiving $s$ given $y^{c}$, and then choose the optimal contract at date 0.

At date 0.5 , the borrowers and lenders trade off the benefit from renegotiating a new contract to reduce Type I errors (errors due to false alarms) as well as Type II errors (errors due to undue optimism) and the renegotiation cost. Let $\underline{R}$ denote renegotiating the contract (e.g., cancel the covenant $y^{c}=y_{H}$ ) and $\underline{\mathrm{NR}}$ denote not renegotiating the contract

\footnotetext{
${ }^{49}$ Note that in equilibrium $D$ should be bigger than $M$. When project A is liquidated, the bank can claim the assets of project B to compensate the difference.
} 
For $s=s_{H}$

If $y^{c}=y_{L}, \quad \underline{\mathrm{R}}$ need $\rho x_{H}+(1-\rho) x_{L}-c>M \operatorname{Prob}\left(y_{L} \mid s_{H}\right)+\left[\rho x_{H}+(1-\rho) x_{L}\right] \operatorname{Prob}\left(y_{H} \mid s_{H}\right)$

$\Rightarrow$ if $\gamma<1-\frac{c}{\rho x_{H}+(1-\rho) x_{L}-M}$ then $\underline{\mathrm{R}}$; Otherwise $\underline{\mathrm{NR}}$

If $y^{c}=y_{H}, \quad \underline{\mathrm{R}}$ by $\rho x_{H}+(1-\rho) x_{L}-c>M$

For $s=s_{L}$

If $y^{c}=y_{L}, \quad \underline{\mathrm{R}}$ need $M-c>M \operatorname{Prob}\left(y_{L} \mid s_{L}\right)+\left[(1-\rho) x_{H}+\rho x_{L}\right] \operatorname{Prob}\left(y_{H} \mid s_{L}\right)$

$\Rightarrow$ if $\gamma<1-\frac{c}{M-(1-\rho) x_{H}-\rho x_{L}}$ then $\underline{\mathrm{R}}$; Otherwise $\underline{\mathrm{NR}}$

If $y^{c}=y_{H}, \quad \underline{\mathrm{NR}}$ because both parties just want to liquidate

At date 0 , the borrower and lender need to choose the optimal covenant to minimize

the expected renegotiation costs or maximize the total surplus (denoted $T S$ )

For $\gamma<1-\frac{c}{M-(1-\rho) x_{H}-\rho x_{L}}$

If choose $y^{c}=y_{L}, \quad T S=\operatorname{Prob}\left(s_{H}\right)\left[\rho x_{H}+(1-\rho) x_{L}-c\right]+\operatorname{Prob}\left(s_{L}\right)(M-c)$

$$
=\frac{1}{2}\left[\rho x_{H}+(1-\rho) x_{L}-c\right]+\frac{1}{2}(M-c)
$$

If choose $y^{c}=y_{H}, \quad T S=\operatorname{Prob}\left(s_{H}\right)\left[\rho x_{H}+(1-\rho) x_{L}-c\right]+\operatorname{Prob}\left(s_{L}\right) M$

$$
\begin{aligned}
& =\frac{1}{2}\left[\rho x_{H}+(1-\rho) x_{L}-c\right]+\frac{1}{2} M \\
& \Rightarrow y^{c *}=y_{H}, \operatorname{Prob}(\text { Renegotiation })=\frac{1}{2}
\end{aligned}
$$

For $1-\frac{c}{M-(1-\rho) x_{H}-\rho x_{L}} \leq \gamma<1-\frac{c}{\rho x_{H}+(1-\rho) x_{L}-M}$

If choose $y^{c}=y_{L}, \quad T S=\operatorname{Prob}\left(s_{H}\right)\left[\rho x_{H}+(1-\rho) x_{L}-c\right]$

$$
\begin{aligned}
& +\operatorname{Prob}\left(s_{L}\right)\left[\operatorname{Prob}\left(y_{H} \mid s_{L}\right)\left((1-\rho) x_{H}+\rho x_{L}\right)+\operatorname{Prob}\left(y_{L} \mid s_{L}\right) M\right] \\
& =\frac{1}{2}\left[\rho x_{H}+(1-\rho) x_{L}-c\right]+\frac{1}{2}\left[\left((1-\rho) x_{H}-\rho x_{L}\right)(1-\gamma)+M \gamma\right]
\end{aligned}
$$

If choose $y^{c}=y_{H}, \quad T S=\operatorname{Prob}\left(s_{H}\right)\left[\rho x_{H}+(1-\rho) x_{L}-c\right]+\operatorname{Prob}\left(s_{L}\right) M=\frac{1}{2}\left[\rho x_{H}+(1-\rho) x_{L}-c\right]+1 / 2 M$

$$
\Rightarrow y^{c *}=y_{H}, \operatorname{Prob}(\text { Renegotiation })=\frac{1}{2}
$$

For $1-\frac{c}{\rho x_{H}+(1-\rho) x_{L}-M} \leq \gamma<1-\frac{c}{(2 \rho-1)\left(x_{H}-x_{L}\right)}$

If choose $y^{c}=y_{L}, \quad T S=\operatorname{Prob}\left(s_{H}\right)\left[\operatorname{Prob}\left(y_{H} \mid s_{H}\right)\left(\rho x_{H}+(1-\rho) x_{L}\right)+\operatorname{Prob}\left(y_{L} \mid s_{H}\right) M\right]$

$$
\begin{aligned}
& +\operatorname{Prob}\left(s_{L}\right)\left[\operatorname{Prob}\left(y_{H} \mid s_{L}\right)\left((1-\rho) x_{H}+\rho x_{L}\right)+\operatorname{Prob}\left(y_{L} \mid s_{L}\right) M\right] \\
& =\frac{1}{2}\left[\left(\rho x_{H}+(1-\rho) x_{L}\right) \gamma+M(1-\gamma)\right]+\frac{1}{2}\left[\left((1-\rho) x_{H}+\rho x_{L}\right)(1-\gamma)+M \gamma\right]
\end{aligned}
$$


If choose $y^{c}=y_{H}, \quad T S=\operatorname{Prob}\left(s_{H}\right)\left[\left(\rho x_{H}+(1-\rho) x_{L}\right)-c\right]+\operatorname{Prob}\left(s_{L}\right) M$

$$
\begin{aligned}
& =\frac{1}{2}\left[\left(\rho x_{H}+(1-\rho) x_{L}\right)-c\right]+\frac{1}{2} M \\
& \Rightarrow y^{c *}=y_{H}, \operatorname{Prob}(\text { Renegotiation })=\frac{1}{2}
\end{aligned}
$$

For $\gamma \geq 1-\frac{c}{(2 \rho-1)\left(x_{H}-x_{L}\right)}$

The $T S$ formulas are the same as in the last case, but the value of $\gamma$ changes.

$$
\Rightarrow y^{c *}=y_{L}, \operatorname{Prob}(\text { Renegotiation })=0
$$

Proof of Proposition 2: First of all, after adding project B, the whole tradeoff is unchanged due to $r(I)+x_{L}<M .^{50}$ When $\gamma \geq 1-\frac{c}{(2 \rho-1)\left(x_{H}-x_{L}\right)}$, the covenant can perfectly govern project A. At date 0 after signing the contract, the firm will choose the optimal investment level to maximize $\operatorname{Prob}($ continue $) r(I)-I \Rightarrow I^{*}=I^{S B}<I^{F B}$ where $r^{\prime}\left(I^{S B}\right)=2$. When $\gamma<1-\frac{c}{(2 \rho-1)\left(x_{H}-x_{L}\right)}$, the covenant is too restrictive. At date 0.5 , the bank will only let project A continue when it receives $s_{H}$ and require $1-\beta$ shares of additional surplus which is $\rho x_{H}+(1-\rho) x_{L}+r(I)-M$. Therefore, at date 0 after signing the contract, the firm will choose the optimal investment level to maximize $\beta \operatorname{Prob}($ continue $) r(I)-I \Rightarrow r^{\prime}\left(I^{*}\right)=\frac{2}{\beta}$ and $I^{*}<I^{S B}<I^{F B}$. Since $r($.$) is a concave function, it is easy to show that \frac{\partial\left(I^{S B}-I^{*}\right)}{\partial \beta}<0$

\footnotetext{
${ }^{50}$ One can consider replacing the old $x_{H}$ and $x_{L}$ with $x_{H}+r(I)$ and $x_{L}+r(I)$.
} 


\section{Appendix II: Procedures for Checking Renegotiation Status}

1. Read the manually collected 67 renegotiations and find the similarities. The amendments are usually in the format below.

2. Try different searching patterns for the 67 cases until it captures all of them.

3. Download all the 10-K, 10-Q, and 8-K filings from Edgar between the initiation date and maturity date. Clean the files with html format following Li (2008).

4. Apply the finalized searching pattern to all the files and extract the relevant blocks of texts.

5. Go through the block of texts and identify the renegotiation.

EXHIBIT 10.1

\section{FIRST AMENDMENT TO CREDIT AGREEMENT AND CONSENT OF GUARANTORS}

This FIRST AMENDMENT TO CREDIT AGREEMENT AND CONSENT OF GUARANTORS (this "AMENDMENT") is dated as of December 4, 2001, but upon its effectiveness in accordance with its terms shall be effective as of October 28, 2001 and entered into by and among FLEETWOOD ENTERPRISES, INC. ("FLEETWOOD"), FLEETWOOD HOLDINGS, INC. and its Subsidiaries listed on the signature pages hereof (collectively, "FMC"), FLEETWOOD RETAIL, INC. and its Subsidiaries listed on the signature pages hereof (collectively, "FRC"), the banks and other financial institutions signatory hereto that are parties as Lenders to the Credit Agreement referred to below (the "Lenders"), and BANK OF AMERICA, N.A., as administrative agent and collateral agent (in such capacity, the "Agent") for the Lenders.

\section{RECITALS}

WHEREAS, Fleetwood, the Borrowers, the Lenders, and the Agent have entered into that certain Credit Agreement dated as of July 27, 2001 (the "CREDIT AGREEMENT"; capitalized terms used in 
this Amendment without definition shall have the meanings given such terms in the Credit Agreement); and

WHEREAS, the Borrowers have requested amendments to the Credit Agreement to modify certain covenants;

and

WHEREAS, the Lenders and the Agent are willing to agree to the amendments requested by the Loan Parties, on the terms and conditions set forth in this Amendment;

NOW THEREFORE, in consideration of the premises and the mutual agreements set forth herein, Fleetwood, the Borrowers, the Lenders, and the Agent agree as follows: 


\section{Appendix III: Excerpts of Amendment Files}

\section{Example 1: CSK Auto Inc. Renegotiation on February 17, 2000}

Subsection 1.1 of the Credit Agreement is hereby amended by deleting in its entirety the definitions of ... "Consolidated Net Income" and substituting in lieu thereof, respectively, the following:

"Consolidated Net Income": for any period, net income of the Company and its Subsidiaries, determined on a consolidated basis in accordance with GAAP; provided that: (i) the net income (but not loss) of any Person that is not a Subsidiary or that is accounted for by the equity method of accounting shall be included only to the extent of the amount of dividends or distributions paid in cash to the Company or a wholly-owned Subsidiary, provided, further, that the non-cash charges associated with losses attributable to the PartsAmerica Investment shall be excluded, (ii) the net income of any Person acquired in a pooling of interests transaction for any period prior to the date of such acquisition shall be excluded and (iii) net income of any Subsidiary shall be excluded to the extent that the declaration or payment of dividends or similar distributions by that Subsidiary of that net income is prohibited or not permitted at the date of determination.

\footnotetext{
The corresponding part from the original contract

"Consolidated Net Income": for any period, net income of the Company and its Subsidiaries, determined on a consolidated basis in accordance with GAAP; provided that: (i) the net income (but not loss) of any Person that is not a Subsidiary or that is accounted for by the equity method of accounting shall be included only to the extent of the amount of dividends or distributions paid in cash to the Company or a wholly-owned Subsidiary, (ii) the net income of any Person acquired in a pooling of interests transaction for any period prior to the date of such acquisition shall be excluded and (iii) net income of any Subsidiary shall be excluded to the extent that the declaration or payment of dividends or similar distributions by that Subsidiary of that net income is prohibited or not permitted at the date of determination.
} 


\section{Example 2: Heidrick \& Struggles International Inc. Renegotia- tion on March 25, 2002}

1.10. Section 6.12 .1 of the Credit Agreement is amended and restated to read as set forth below:

SECTION 6.12.1. Minimum Consolidated EBITDA. The Borrower will not permit at any time Consolidated EBITDA, determined as of the end of each of its fiscal quarters set forth below for the applicable measurement period set forth below ending with the end of such fiscal quarter to be less than the applicable amount set forth below:

MEASUREMENT PERIOD

FISCAL QUARTER ENDING THEN ENDING

March 31, 2002

June 30, 2002

September 30, 2002

December 31, 2002

March 31, 2003

June 30, 2003

September 30, 2003

December 31, 2003

March 31, 2004 and each

fiscal quarter thereafter
CONSOLIDATED EBITDA SHALL NOT BE LESS THAN:

$\$(4,000,000)$

$\$ 4,000,000$

$\$ 12,000,000$

$\$ 17,000,000$

$\$ 25,000,000$

$\$ 25,000,000$

$\$ 35,000,000$

$\$ 35,000,000$

$\$ 45,000,000$ 


\section{PERIOD}

Fiscal Quarter ended on the last Sunday in October 2001

Two Fiscal Quarters ended on the last Sunday in January 2002

Three Fiscal Quarters ended on the last Sunday in April 2002

Four Fiscal Quarters ended on the last Sunday in July 2002
FREE CASH FLOW

$\$(5,000,000)$

$\$(21,000,000)$

$\$(14,000,000)$

$\$(3,000,000)$

"FREE CASH FLOW" means, with respect to any fiscal period for Fleetwood on a consolidated basis, (a) EBITDA; PLUS (b) any New Capital Proceeds Amount; plus (c) an amount of not more than $\$ 7,350,000$ paid or accrued prior to the end of the January 2002 Fiscal Quarter in connection with the settlement of the class action lawsuit BRISTOW ET. AL V. FLEETWOOD ENTERPRISES, INC.; LESS (d) the sum of (i) the difference (but in no event less than zero) of (x) Federal, state, local and foreign income taxes paid in cash MINUS (y) to the extent such amounts are included in clause (x), taxes paid in cash as a result of any gain recognized in connection with the Subordinated Debt Exchange and any cash tax refunds received in respect of Federal, state, local and foreign taxes previously paid; (ii) interest expense paid in cash; (iii) Capital Expenditures (excluding Capital Expenditures funded with Debt other than the Revolving Loans); (iv) scheduled principal payments of Debt; (v) Distributions paid in cash by Fleetwood or the Fleetwood Trust; and (vi) without duplication of clause (v), payments made in cash on the Subordinated Debt. 


\section{The corresponding part from the original contract}

7.24 EBITDA.

(a) On a consolidated basis, Fleetwood shall have EBITDA for the portion of the Fiscal Year 2002 then elapsed of not less than the amount set forth below opposite each such Fiscal Quarter:

\section{PERIOD ENDING}

On the last Sunday in October 2001

On the last Sunday in January 2002

On the last Sunday in April 2002

"EBITDA" means, with respect to

PLUS, to the extent deducted in the determination of Adjusted Net Earnings from Operations for that fiscal period, interest expenses, Federal, state, local and foreign income taxes, depreciation and amortization.
EBITDA

$\$ 15,000,000$

$\$ 25,000,000$

$\$ 55,000,000$

\section{Example 4: Warnaco Inc. Renegotiation on September 15, 2005}

Amendment to the definition of "Applicable Margin" in Article I (Definitions, Interpretation and Accounting Terms). The definition of "Applicable Margin" is hereby amended by deleting the table set forth therein and inserting the following new table in its place:

$\begin{array}{cc}\text { BASE RATE } & \text { EURODOLLAR } \\ \text { LOANS } & \text { RATE LOANS } \\ 0.75 \% & 1.75 \% \\ 0.50 \% & 1.50 \% \\ 0.50 \% & 1.50 \% \\ 0.25 \% & 1.25 \%\end{array}$

LEVERAGE RATIO

Greater than or equal to 1.5 to 1

Less than 1.5 to 1 and equal to or greater than 1.25 to 1

Less than 1.25 to 1 and equal to or greater than 1.00 to 1

Less than 1.0 to 1 
The corresponding part from the original contract

\begin{tabular}{|lcc|}
\hline LEVERAGE RATIO & $\begin{array}{c}\text { BASE RATE } \\
\text { LOANS }\end{array}$ & $\begin{array}{c}\text { EURODOLLAR } \\
\text { Rreater than or equal to } 1.5 \text { to } 1\end{array}$ \\
$\quad$ In the event no Margin Reduction Event has occured & $1.50 \%$ & $2.50 \%$ \\
$\quad$ From and after the occurence of the Margin Reduction Event & $1.25 \%$ & $2.25 \%$ \\
Less than 1.5 to 1 and equal to or greater than 1.0 to 1 & $1.25 \%$ & $2.25 \%$ \\
Less than 1.0 to 1 & $1.00 \%$ & $2.00 \%$ \\
\hline
\end{tabular}

\section{Example 5: Encore Medical Corp. Renegotiation on May 7, 2002}

Section 3.2 Amendment to Annex A of the Credit Agreement. Effective as of the Amendment Date, the definition of "Borrowing Base" in Annex A of the Credit Agreement is hereby amended and restated in its entirety to read as follows:

"Borrowing Base" means, at any time, an amount equal to (a) the sum of (i) eightyfive percent $(85.0 \%)$ of the Net Amount of Eligible Accounts; plus (ii) (A) prior to August 7, 2002, sixty percent $(60.0 \%$ ) of the lower of cost (on a first-in, first-out basis) or market value of Eligible Finished Goods Inventory and (B) from August 7, 2002 and thereafter the lesser of (1) sixty percent $(60.0 \%$ ) of the lower of cost (on a first-in, firstout basis) or market value of Eligible Finished Goods Inventory or (2) seventy-five percent $(75.0 \%)$ of the Orderly Liquidation Value of Finished Goods Inventory plus (iii) (A) prior to August 7, 2002, thirty-five percent (35.0\%) of the lower of cost (on a first-in, first-out basis) or market value of Eligible Generic Raw Materials Inventory and (B) from August 7, 2002 and thereafter the lesser of (1) thirty-five percent (35.0\%) of the lower of cost (on a first-in, first-out basis) or market value of Eligible Generic Raw Materials Inventory or (2) seventy-five percent (75.0\%) of the Orderly Liquidation Value of Generic Raw Materials Inventory, minus (b) from August 7, 2002 and thereafter, \$500,000, minus (c) Reserves from time to time established by the Agent in its reasonable credit judgment. 


\section{The corresponding part from the original contract}

"Borrowing Base" means, at any time, an amount equal to (a) the sum of (i) eighty-five percent (85.0\%) of the Net Amount of Eligible Accounts; plus (ii) the lesser of (A) sixty percent (60.0\%) of the lower of cost (on a first-in, first-out basis) or market value of Eligible Finished Goods Inventory or (B) seventy-five percent (75.0\%) of the Orderly Liquidation Value of Finished Goods Inventory plus (iii) the lesser of (A) thirty five percent (35\%) of the lower of cost (on a "first-in, first-out" basis) or market value of Eligible Generic Raw Materials Inventory or (B) seventy-five percent (75.0\%) of the Orderly Liquidation Value of Generic Raw Materials Inventory, minus (b) $\$ 500,000$, minus (c) Reserves from time to time established by the Agent in its reasonable credit judgment. 


\section{Appendix IV: Variable Definitions and Data Sources}

\begin{tabular}{|c|c|c|}
\hline Variable & Description & Data Source \\
\hline \multicolumn{3}{|c|}{ Dependent Variables } \\
\hline RENEG & $\begin{array}{l}\text { An indicator variable that takes the value of one if any major con- } \\
\text { tracting term is renegotiated before maturity. Major contracting } \\
\text { terms include principal, interest, maturity, and accounting-based } \\
\text { contractual features (i.e., financial covenants, accounting-based } \\
\text { performance pricing, and accounting-based borrowing bases). }\end{array}$ & $\begin{array}{l}\text { SEC Edgar } \\
\text { Filings }\end{array}$ \\
\hline INVEST & $\begin{array}{l}\text { The average of quarterly capital expenditures (\#CAPXQ) plus } \\
\text { R\&D (\#XRDQ) scaled by total assets (\#ATQ) starting from the } \\
\text { quarter after signing the debt contract and ending with the quarter } \\
\text { before renegotiation or before maturity in cases where there is no } \\
\text { renegotiation. }\end{array}$ & Compustat \\
\hline $\begin{array}{l}R O A n \\
\text { Test Vari }\end{array}$ & Average ROA over the next $n$ years. & Compustat \\
\hline$D C V$ & $\begin{array}{l}\text { The debt-contracting value of accounting numbers. For any given } \\
\text { year, I estimate an Ordered Probit Model using quarterly data in } \\
\text { the past five years for each Fama-French industry ( } 48 \text { categories): } \\
\qquad P\left(\text { Rating }_{t, i} \leq N\right)=\Phi\left(\sum_{n=1}^{N} \mu_{n}+\sum_{k=1}^{4} \alpha_{k} E_{t-k, i}+\sum_{k=1}^{4} \beta_{k} C O V_{t-k, i}\right. \\
\left.\qquad+\sum_{k=1}^{4} \gamma_{k} L E V_{t-k, i}+\sum_{k=1}^{4} \delta_{k} N W_{t-k, i}\right) \\
\text { where Rating } g_{t, i} \text { is assigned } 1 \text { to companies with the highest S\&P } \\
\text { credit rating in quarter } t, 2 \text { to companies with the second-highest } \\
\text { credit rating, and so on. }\end{array}$ & \\
\hline
\end{tabular}




\begin{tabular}{|c|c|c|}
\hline Variable & Description & Data Source \\
\hline & $\begin{array}{l}E_{t-k, i} \text { is EBITDA divided by total assets } \\
((\# \mathrm{IBQ}+\# \mathrm{XINTQ}+\# \mathrm{TXTQ}+\# \mathrm{DPQ}) / \# \mathrm{ATQ}) \text { in quar- } \\
\text { ter } t-k . \quad C O V_{t-k, i} \text { is interest coverage (EBITDA } \\
(\# \mathrm{IBQ}+\# \mathrm{XINTQ}+\# \mathrm{TXTQ}+\# \mathrm{DPQ}) \text { divided by total inter- } \\
\text { est expense (\#XINTQ) ).LEV } V_{t-k, i} \text { is long-term debt divided } \\
\text { by total assets (\#DLTTQ/\#ATQ) in quarter } t-k . N W_{t-k, i} \\
\text { is net worth divided by total assets (\#CEQQ/\#ATQ). Each } \\
\text { regression requires at least } 100 \text { firm-quarter observations. } \\
\text { Specifically, } D C V \text { is measured as Somers' D, a goodness-of-fit } \\
\text { statistic. }\end{array}$ & Compustat \\
\hline RENEGDCV & $\begin{array}{l}\text { One minus the predicted probability of renegotiation by imput- } \\
\text { ing } D C V \text { and the means of other independent variables using } \\
\text { the coefficients from column (2) of Table } 6 \text {. }\end{array}$ & Table 6 \\
\hline \multicolumn{3}{|c|}{ Firm Characteristics Variables } \\
\hline LNASSET & $\begin{array}{l}\text { The average of natural log of book assets (\#ATQ) over quarter } \\
t-3 \text { to } t \text {. }\end{array}$ & Compustat \\
\hline$D T E$ & $\begin{array}{l}\text { The average of debt (\#DLCQ+\#DLTTQ) to EBITDA (\#OIB- } \\
\text { DPQ) ratio over quarter } t-3 \text { to } t\end{array}$ & Compustat \\
\hline$L E V$ & $\begin{array}{l}\text { The average of debt (\#DLCQ+\#DLTTQ) to book assets } \\
\text { (\#ATQ) ratio over quarter } t-3 \text { to } t \text {. }\end{array}$ & Compustat \\
\hline$R O A$ & $\begin{array}{l}\text { The average of EBITDA (\#OIBDPQ) to book assets (\#ATQ) } \\
\text { ratio over quarter } t-3 \text { to } t \text {. }\end{array}$ & Compustat \\
\hline$M T B$ & $\begin{array}{l}\text { The average of (\#LTQ+\#PSTKL-\#TXDITCQ } \\
\left.+\# \mathrm{PRCCQ}^{*} \# \mathrm{CSHOQ} / \# \mathrm{ATQ}\right) \text { market-to-book over quarter } \\
t-3 \text { to } t\end{array}$ & Compustat \\
\hline
\end{tabular}




\begin{tabular}{|c|c|c|}
\hline Variable & Description & Data Source \\
\hline ZSCORE & $\begin{array}{l}\text { The average of zscore over quarter } t-3 \text { to } t \\
\text { zscore }=1.2^{*}((\# \mathrm{ACTQ}-\# \mathrm{LCTQ}) / \# \mathrm{ATQ}) \\
+1.4^{*}(\# \mathrm{REQ} / \# \mathrm{ATQ})+3.3^{*}(\# \mathrm{PIQ} / \# \mathrm{ATQ}) \\
+0.6^{*}\left(\# \mathrm{PRCCQ}{ }^{*} \# \mathrm{CSHOQ} / \# \mathrm{LTQ}\right)+0.999^{*}(\# \mathrm{SALEQ} / \# \mathrm{ATQ})\end{array}$ & Compustat \\
\hline STDROA & $\begin{array}{l}\text { The standard deviation of EBITDA (\#OIBDPQ) to book as- } \\
\text { sets (\#ATQ) ratio over the past eight quarters. }\end{array}$ & Compustat \\
\hline$Q$ & $\begin{array}{l}\text { The ratio of market value (\#AT+\#PRCC_F*\#CSHO-\#CEQ- } \\
\text { \#TXDB) to book assets (\#AT). }\end{array}$ & Compustat \\
\hline$C F$ & The cash flow (\#IB+\#DP) scaled by total assets (\#AT). & Compustat \\
\hline$R K$ & $\begin{array}{l}\text { Debt overhang correction defined as in Hennessy et al. (2007). } \\
\text { More precisely, this measure is the product of long-term debt } \\
\text { scaled by the capital stock, recovery ratio, and the value of the } \\
\text { claim paying one dollar at default. }\end{array}$ & $\begin{array}{l}\text { Compustat/CRSP } \\
\text { /Moody's }\end{array}$ \\
\hline$K Z I N D$ & $\begin{array}{l}\text { The financial constraint index from Kaplan and Zingales } \\
\text { (1997). }\end{array}$ & Compustat \\
\hline$T A N G$ & $\begin{array}{l}\text { The liquidation value }\left(\left(\# \mathrm{CHE}+0.715^{*} \# \mathrm{RECT}+0.547^{*} \# \mathrm{INVT}\right.\right. \\
\left.\left.+0.535^{*} \# \mathrm{PPENT}\right) / \# \mathrm{AT}\right) \text { following Berger et al. }(1996) \text {. }\end{array}$ & Compustat \\
\hline$L E A S E$ & $\begin{array}{l}\text { The capitalized lease expenditure (lagged \#MRC1 } * 10) \text { scaled } \\
\text { by total assets }(\# \mathrm{AT}) .\end{array}$ & Compustat \\
\hline$L A G R O A$ & $\begin{array}{l}\text { Past } R O A \text { average over the same horizon as the dependent } \\
\text { variables. }\end{array}$ & Compustat \\
\hline STDINVEST & $\begin{array}{l}\text { The standard deviation of investment (\#CAPX+\#XRD) } \\
\text { scaled by total assets (\#AT) over past five years. }\end{array}$ & Compustat \\
\hline$A G E$ & The number of years since IPO. & Compustat \\
\hline$S A L E G$ & The growth of sales (\#SALE) relative to last year. & Compustat \\
\hline
\end{tabular}




\begin{tabular}{|c|c|c|}
\hline Variable & Description & Data Source \\
\hline \multicolumn{3}{|c|}{ Lender Characteristics Variables } \\
\hline INSTLP & $\begin{array}{l}\text { The fraction of Type B, Type C, or Type D loans in the port- } \\
\text { folio of the lead lender over past five years, multiplied by }-1 \text {. }\end{array}$ & DealScan \\
\hline FLENDER & $\begin{array}{l}\text { the proportion of the syndicated loan deal held by foreign } \\
\text { lenders, multiplied by }-1 \text {. }\end{array}$ & DealScan \\
\hline \multicolumn{3}{|c|}{ Loan Characteristics Variables } \\
\hline LNMATURITY & $\begin{array}{l}\text { The natural log of the average maturity of all tranches in the } \\
\text { deal, weighted by the amount of each tranche. }\end{array}$ & DealScan \\
\hline$D A M O U N T$ & $\begin{array}{l}\text { The natural log of the sum of the amounts of all tranches in } \\
\text { each deal scaled by total assets. }\end{array}$ & DealScan \\
\hline$S P R E A D$ & $\begin{array}{l}\text { The average all-in-drawn spread over LIBOR of all tranches in } \\
\text { the deal, weighted by the amount of each tranche. }\end{array}$ & DealScan \\
\hline NLENDER & The number of lenders in the lending deal. & DealScan \\
\hline$R E V L V$ & $\begin{array}{l}\text { The average of indicators for all tranches in the deal, weighted } \\
\text { by the amount of each tranche. For each tranche, the indicator } \\
\text { is equal to one if the tranche is a revolving line of credit. }\end{array}$ & DealScan \\
\hline$P G$ & $\begin{array}{l}\text { The average of indicators for all tranches in the deal, weighted } \\
\text { by the amount of each tranche. For each tranche, the indicator } \\
\text { is equal to one if the tranche contains performance pricing. }\end{array}$ & DealScan \\
\hline$B O W B A S E$ & $\begin{array}{l}\text { The average of indicators for all tranches in the deal, weighted } \\
\text { by the amount of each tranche. For each tranche, the indicator } \\
\text { is equal to one if the tranche contains a borrowing base. }\end{array}$ & DealScan \\
\hline COVIS & $\begin{array}{l}\text { An indicator variable that takes the value of one if there is any } \\
\text { income-statement-based covenant including debt-to-earnings } \\
\text { ratio, }\end{array}$ & \\
\hline
\end{tabular}




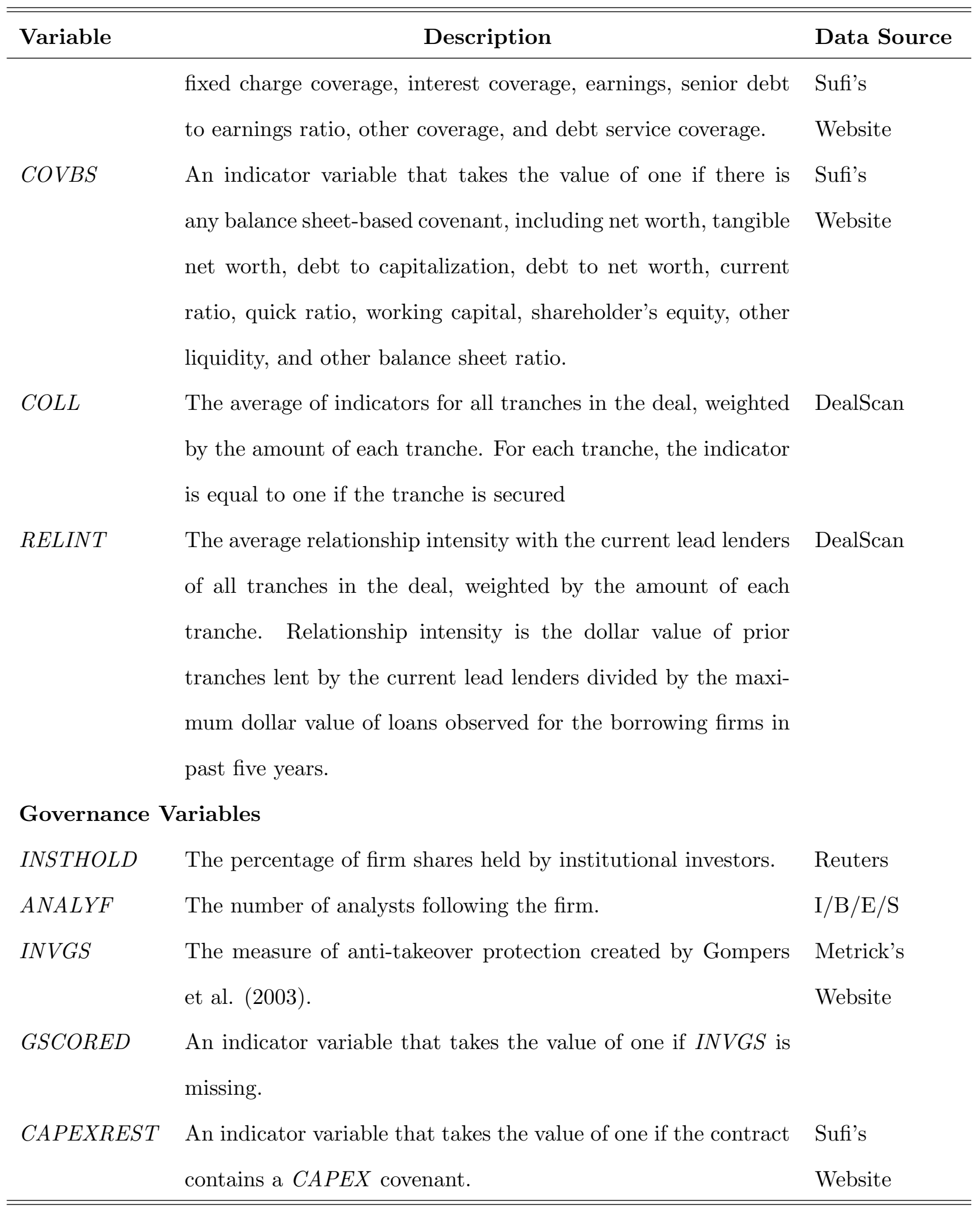




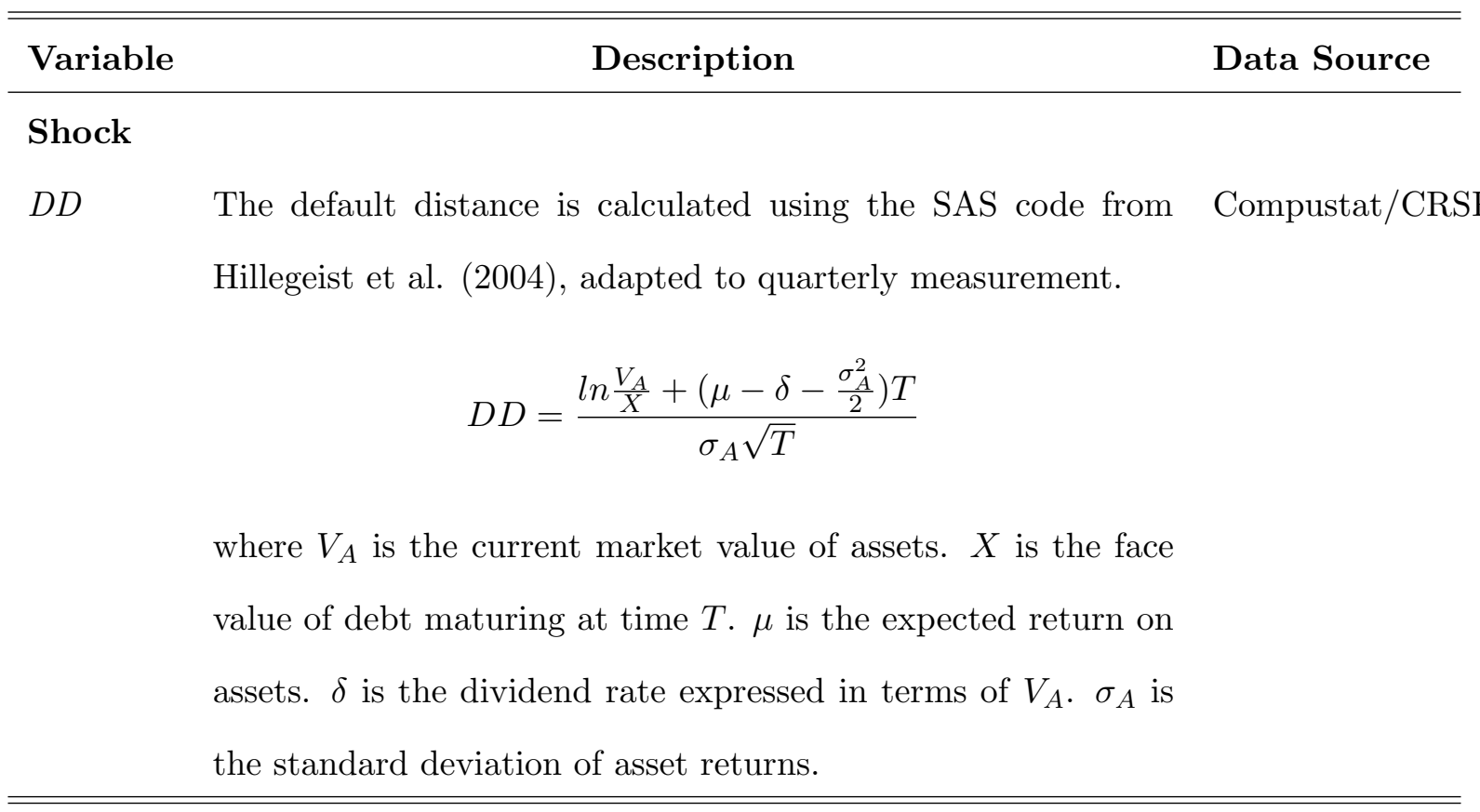




\section{References}

Aboody, D. 1996. Recognition versus disclosure in the oil and gas industry. Journal of Accounting Research 34, 21-32.

Aghion, P., and P. Bolton. 1992. An incomplete contracts approach to financial contracting. Review of Economic Studies 59, 473-494.

Alti, A. 2003. How sensitive is investment to cash flow when financing is frictionless? The Journal of Finance 63, 707-722.

Amstrong, G., W. Guay, and J. Weber. 2010. The role of information and financial reporting in corporate governance and contracting. Journal of Accounting and Economics 50, 179-234.

Asquith, P., A. Beatty, and J. Weber. 2005. Performance pricing in bank debt contracts. Journal of Accounting and Economics 40, 101-128.

Aivazian, V., and J. Callen. 1980. Future investment opportunities and the value of the call provision on a bond: Comment. The Journal of Finance 35, 10511054.

Baber, W., S. Kang, and Y. Li. 2011. Modeling discretionary accrual reversal and the balance sheet as an earnings management constraint. The Accounting Review, Forthcoming.

Ball, R., R. M. Bushman, and F. P. Vasvari. 2008. The debt-contracting value of accounting information and loan syndicate structure. Journal of Accounting Research 46, 247-287.

Barton, J., and P. Simko. 2002. The balance sheet as an earnings management constraint. The Accounting Review 77, 1-27.

Beatty, A. 2008. Discussion of the debt-contracting value of accounting information and loan syndicate structure. Journal of Accounting Research 46, 289-296.

Beatty, A., B. Ke, and K. Petroni. 2002. Earnings management to avoid earnings 
declines across publicly and privately held banks. The Accounting Review 77, $547-570$.

Beatty, A., S. Liao, and J. Weber. 2010a. The effect of private information and monitoring on the role of accounting quality in investment decisions. Contemporary Accounting Research 27, 17-47.

Beatty, A., S. Liao, and J. Weber. 2010b. Financial reporting quality, private information, monitoring, and the lease-versus-buy decision. The Accounting Review 85, 1215-1238.

Beatty, A., J. Weber, and J. Yu. 2008. Conservatism and debt. Journal of Accounting and Economics 45, 154-174.

Beneish, D., and E. Press. 1993. Costs of technical violation of accounting-based debt covenants. The Accounting Review 68, 233-257.

Benmelech, E., and N. Bergman. 2008. Liquidation values and the credibility of financial contract renegotiation: Evidence from U.S. airlines. Quarterly Journal of Economics 123, 1635-1677.

Bens, D. A., and S. J. Monahan. 2004. Disclosure quality and the excess value of diversification. Journal of Accounting Research 42, 691-730.

Berger, P., E. Ofek, and I. Swary. 1996. Investor valuation and abandonment option. Journal of Financial Economics 42, 257-287.

Bergman, Y., and J. Callen. 1991. Opportunistic underinvestment in debt renegotiation and capital structure. Journal of Financial Economics 29, 137-171.

Bharath, S., J. Sunder, and S. Sunder. 2008. Accounting quality and debtcontracting. The Accounting Review 83, 1-28.

Biddle, G., and G. Hilary. 2006. Accounting quality and firm-level capital investment. The Accounting Review 81, 963-982.

Biddle, G., G. Hilary, and R. Verdi. 2009. How does financial reporting quality relate to investment efficiency? Journal of Accounting Research 48, 112-131. 
Bowen, R.M., L. DuCharme, and D. Shores. 1995. Stakeholders' implicit claims and accounting method choice. Journal of Accounting and Economics 20, 255295.

Bushman, R. M., A. Smith, and R. Wittenberg-Moerman. 2010. Price discovery and dissemination of private information by loan syndicate participants. Journal of Accounting Research 48, 921-972.

Campbell, T., and W. Kracaw. 1980. Information production, market signaling, and the theory of intermediation. The Journal of Finance 35, 863-882.

Chava, S., and M. Roberts. 2008. How does financing impact investment? The role of debt covenants. The Journal of Finance 63, 2085-2121.

Chen, F., Y. Dou, H. Hurwitz, and J. Li. 2011a. Relationship lending, credit market competition and accounting conservatism in debt-contracting. Working Paper. University of Toronto.

Chen, F., O.-K. Hope, Q. Li, and X. Wang. 2011b. Financial reporting quality and investment efficiency of private firms in emerging markets. The Accounting Review 86, 1255-1288.

Chen, T., and X. Martin. 2011. Do bank affiliated analysts benefit from information sharing? Journal of Accounting Research 49, 633-675.

Chen, W., and K. Wei. 1993. Creditors' decisions to waive violations of accountingbased debt covenants. The Accounting Review 68, 218-232.

Christensen, H., and V. Nikolaev. 2010. Loan ownership dispersion and control over mandatory GAAP changes. Working Paper. University of Chicago.

Christensen, H., and V. Nikolaev. 2011. Capital versus performance covenants in debt contracts. Journal of Accounting Research, Forthcoming.

Costello, A., and R. Wittenberg-Moerman. 2011. The impact of financial reporting quality on debt-contracting: Evidence from internal control weakness reports. Journal of Accounting Research 49, 97-136. 
Cummins, J., K. Hassett, and S. Oliner. 2006. Investment behavior, observable expectations, and internal funds. American Economic Review 96, 796-810.

DeAngelo H., L., DeAngelo, and D., Skinner. 1994. Accounting choice in troubled companies. Journal of Accounting and Economics 17, 113-143.

Dechow, P., and I. Dichev. 2002. The quality of accruals and earnings. The Accounting Review 77, 35-59.

DeFond, M., and J. Jiambalvo. 1994. Debt covenant violation and manipulation of accruals. Journal of Accounting and Economics 17, 145-176.

Demerjian, P. 2011. Accounting standards and debt covenants: Has the "balance sheet approach" damaged the balance sheet? Journal of Accounting and Economics, Forthcoming.

Diamond, D. W. 1984. Financial intermediation and delegated monitoring. Review of Economic Studies 51, 393-416.

Diamond, D. W. 1991. Monitoring and reputation, the choice between bank loans and directly placed debt. Journal of Political Economy 99, 689-721.

Dichev, I., A. Beatty, and J. Weber. 2002. The role and characteristics and accounting-based performance pricing in private debt contracts. Working Paper. MIT.

Dichev, I., and D. Skinner. 2002. Large-sample evidence on the debt covenant hypothesis. Journal of Accounting Research 40, 1091-1123.

Dou, Y., O.-K. Hope, and W. Thomas. 2011. Relationship-specificity, contract enforceability, and income smoothing. Working Paper. University of Toronto.

Douglas, A. 2003. Corporate investment incentives and accounting-based debt covenants. Contemporary Accounting Research 20, 645-583.

Dye, R. 1985. Costly contract contingencies. International Economic Review 26, 233-250.

Easley, D., and M. O'Hara. 2004. Information and the cost of capital. The 
Journal of Finance 59, 1553-1583.

El-Gazzar, S., and V. Pastena. 1990. Negotiated accounting rules in private financial contracts. Journal of Accounting and Economics 12, 381-396.

Farrell, J., and R. Gibbons. 1989. Cheap-talk with two audiences. American Economic Review 79, 1214-1223.

Flannery, M., and X. Wang. 2011. Borrowing base revolvers: Liquidity for risky firms. Working Paper. University of Florida.

Francis, J., R. LaFond, P. Olsson, and K. Schipper. 2004. Costs of equity and earnings attributes. The Accounting Review 79, 967-1010.

Francis, J., R. LaFond, P. Olsson, and K. Schipper. 2005. The market pricing of accruals quality. Journal of Accounting and Economics 39, 295-327.

Francis, J., D.J. Nanda, and P. Olsson. 2008. Voluntary disclosure, earnings quality, and cost of capital. Journal of Accounting Research 46, 53-99.

Frankel, R., and C. M. Lee. 1998. Accounting valuation, market expectation, and cross-sectional stock returns. Journal of Accounting and Economics 25, 283-319.

Frankel, R., and L. Litov. 2007. Financial accounting characteristics and debt covenants. Working Paper. Washington University in Saint Louis.

Frankel, R., C. Seethamraju, and T. Zach. 2008. GAAP goodwill and debtcontracting efficiency: Evidence from net-worth covenants. Review of Accounting Studies 13, 87-118.

Gigler, F. 1994. Self-enforcing voluntary disclosure. Journal of Accounting Research 32, 224-240.

Gigler, F., C. Kanodia, H. Sapra, and R. Venugopalan. 2009. Accounting conservatism and the efficiency of debt contracts. Journal of Accounting Research 47, 767-797.

Gompers, P., J. Ishii, and A. Metrick. 2003. Corporate governance and equity 
prices. Quarterly Journal of Economics 118, 107-155.

Gorton, G., and J. Kahn. 2000. The design of bank loan contracts. Review of Financial Studies 13, 331-364.

Gorton, G., and G. Pennacchi. 1995. Banks and loan sales: Marketing nonmarketable assets. Journal of Monetary Economics 35, 389-411.

Grossman, S. J., and O. D. Hart. 1986. The costs and benefits of ownership, A theory of vertical and lateral integration. Journal of Political Economy 94, 691-719.

Hale, G., and J. Santos. 2009. Do banks price their informational monopoly? Journal of Financial Economics 93, 185-206.

Hart, O. D., and J. Moore. 1988. Incomplete contracts renegotiation. Econometrica $56,755-785$.

Hart, O. D., and J. Moore. 1990. Property rights and the nature of the firm. Journal of Political Economy 98, 1119-1158.

Hayashi, F. 1982. Tobin's marginal q and average q: A neoclassical interpretation. Econometrica 50, 213-224.

Healy, M., and K. Palepu. 1990. Effectiveness of accounting-based dividend covenants. Journal of Accounting and Economics 12, 97-133.

Hennessy, C., A. Levy, and T. Whited. 2007. Testing Q theory with financing frictions. Journal of Financial Economics 83, 691-717.

Hillegeist, S., E. Keating, D. Cram, and K, Lundstedt. 2004. Assessing the probability of bankruptcy. Review of Accounting Studies 9, 5-34.

Holthausen, R.W. 1981. Evidence on the effect of bond covenants and management compensation contracts on the choice of accounting techniques: The case of the depreciation switchback. Journal of Accounting and Economics 3, 73-109.

Holthausen, R., and R. Leftwich. 1983. The economic consequences of accounting 
choice, implications of costly contracting and monitoring. Journal of Accounting and Economics 5, 77-117.

Hope, O.-K., and W. B. Thomas. 2008. Managerial empire building and firm disclosure. Journal of Accounting Research 46, 591-626.

Houston, J., and C. James. 1996. Bank information monopolies and the mix of private and public debt claims. The Journal of Finance 51, 1863-1889.

Ioannidou, V., and S. Ongena. 2010. "Time for a change": Loan conditions and bank behavior when firms switch banks. The Journal of Finance 65, 18471877.

Ivashina, V., and Z. Sun. 2010. Institutional stock trading on loan market information. Journal of Financial Economics 100, 284-303.

Kanodia, C., and D. Lee. 1998. Investment and disclosure, the disciplinary role of periodic performance reports. Journal of Accounting Research 36, 33-55.

Kaplan, S.N., and Zingales, L. 1997. Do investment-cash flow sensitivities provide useful measures of financing constraints? Quarterly Journal of Economics 112, $169-215$.

Khan, M., and R.L. Watts. 2009. Estimation and empirical properties of a firmyear measure of accounting conservatism. Journal of Accounting and Economics 48, 132-150.

Kiefer, N. 1988. Economic duration data and hazard functions. Journal of Economic Literature 26, 646-679.

Kim, J., B. Song, and L. Zhang. 2011. Internal control weakness and bank loan contracting: Evidence from SOX Section 404 disclosures. The Accounting Review 86, 1157-1188.

Klein, B., R. G. Crawford, and A. A. Alchian. 1978. Vertical integration, appropriable rents, and the competitive contracting process. Journal of Law and Economics 21, 297-326. 
Lambert, R. 2010. Discussion of "Implications for GAAP from analysis of positive research in accounting." Journal of Accounting and Economics 50, 287-295.

Leftwich, R. 1981. Evidence of the impact of mandatory changes in accounting principles on corporate loan agreements. Journal of Accounting and Economics 3, 3-36.

Leftwich, R. 1983. Accounting information in private markets: Evidence from private lending agreements. The Accounting Review 58, 23-41.

Leland, H., and H. Pyle. 1977. Informational asymmetries, financial structure, and financial intermediation. The Journal of Finance 32, 371-387.

Li, F. 2008. Annual report readability, current earnings, and earnings persistence. Journal of Accounting and Economics 45, 221-247.

Li, N. 2010. Negotiated measurement rules in debt contracts. Journal of Accounting Research 48, 1103-1144.

Li, N. 2011. The use of accounting accruals in debt contracts: Evidence from the measurement of financial covenants. Working paper. London Business School.

Lin, D., and L. Wei. 1989. The robust inference for the Cox proportional hazards model. Journal of the American Statistical Association 84, 1074-1078.

Liu, C., and S. Ryan. 1995. The effect of bank loan portfolio composition on the market reaction to and anticipation of loan loss provisions. Journal of Accounting Research 44, 77-94.

Malmquist, D. 1990. Efficient contracting and the choice of accounting method in the oil and gas industry. Journal of Accounting and Economics 12, 173-205.

Massoud, N., D. Nandy, A. Saunders, and K. Song. 2010. Do hedge funds trade on private information? Evidence from syndicate lending and short-selling. Journal of Financial Economics 99, 477-499.

McNichols, M. 2002. Discussion of the quality of accruals and earnings: The role of accrual estimation errors. The Accounting Review 77, 61-69. 
McNichols, M., and S. Stubben. 2008. Does earnings management affect firms' investment decisions? The Accounting Review 83, 1571-1603.

Myers, S.C. 1977. Determinants of corporate borrowing. Journal of Financial Economics 5, 147-175.

Nini, G., D. Smith, and A. Sufi. 2009a. Creditor control rights and firm investment policy. Journal of Financial Economics 92, 400-420.

Nini, G., D. Smith, and A. Sufi. 2009b. Creditor control rights, corporate governance, and firm value. Working Paper. University of Chicago.

Pennacchi, G. 1988. Loan sales and the cost of bank capital. The Journal of Finance 43, 375-396.

Petersen, M. A. 2008. Estimating standard errors in finance panel data sets: Comparing approaches. Review of Financial Studies 22, 435-480.

Raman, K., and H. Shahrur. 2008. Relationship-specific investments and earnings management: Evidence on corporate suppliers and customers. The Accounting review 83, 1041-1081.

Rajan, R. 1992. Insiders and outsiders, the relationship between informed and arm's-length debt. The Journal of Finance 47, 1367-1400.

Roberts, M., and A. Sufi. 2009a. Renegotiation of financial contracts, evidence from private credit agreements. Journal of Financial Economics 93, 159-184.

Roberts, M., and A. Sufi. 2009b. Control rights and capital structure: An empirical investigation. The Journal of Finance 64, 1657-1695.

Roberts, M. 2010. The role of dynamic renegotiation and asymmetric information in financial contracting. Working Paper. University of Pennsylvania.

Rubinstein, A. 1982. Perfect equilibrium in a bargaining model. Econometrica 50, 97-109.

Santos, J., and A. Winton. 2008. Bank loans, bonds, and information monopolies across the business cycle. The Journal of Finance 63, 1315-1359. 
Schenone, C. 2010. Lending relationships and information rents, do banks exploit their information advantages? Review of Financial Studies 23, 1149-1199.

Segal, I. 1999. Complexity and renegotiation: A foundation for incomplete contracts. Review of Economic Studies 66, 57-82.

Sharpe, S. 1990. Asymmetric information, bank lending and implicit contracts, a stylized model of customer relationships. The Journal of Finance 45, 10691087.

Skinner, D. 1993. The investment opportunity set and accounting procedure choice: Preliminary evidence. Journal of Accounting and Economics 16, 407445.

Smith, W., and J. Warner. 1979. On financial contracting, an analysis of bond covenants. Journal of Financial Economics 7, 117-161.

Smith, W., and R. Watts. 1992. The investment opportunity set and corporate financing, dividend, and compensation policies. Journal of Financial Economics $32,263-292$.

Standard \& Poor's. 2007a. A Guide to the Loan Market. Standard \& Poor's, New York.

Sweeney, A. 1994. Debt covenant violations and managers' accounting responses. Journal of Accounting and Economics 17, 281-308.

Sufi, A. 2009. The real effects of debt certification: Evidence from the introduction of bank loan ratings. Review of Financial Studies 22, 1659-1691.

Taylor, A., and A. Sansone. 2007. The Handbook of Loan Syndications and Trading. McGraw-Hill.

Tett, G. 2011. The return of cov-lites hints at more caution not madness. Financial Times.

Tirole, J. 1999. Incomplete contracts: Where do we stand? Econometrica 67, 741-781. 
Verrecchia, R., and J. Webber. 2006. Redacted disclosure. Journal of Accounting Research 44, 791-814.

Watts, R., and J. Zimmerman, 1990. Positive accounting theory: A ten year perspective. The Accounting Review 65, 131-56.

Williamson, O. E. 1975. Markets and Hierarchies, Analysis and Antitrust Implications. New York, NY, Free Press.

Williamson, O. E. 1979. Transaction cost economics, the governance of contractual relations. Journal of Law and Economics 22, 233-261.

Wittenberg-Moerman, R. 2008. The role of information asymmetry and financial reporting quality in debt trading: Evidence from the secondary loan market. Journal of Accounting and Economics 46, 240-260.

Zhang, J. 2008. The contracting benefits of accounting conservatism to lenders and borrowers. Journal of Accounting and Economics 45, 27-54. 


\section{Table 1 Descriptive Statistics}

This table presents summary statistics for firm and loan characteristics and distribution of contracts across years and industries. The sample includes 3,720 private loan agreements for 1,939 borrowers from Nini et al. (2009a). These agreements are collected from the SEC's Edgar electronic filing system over the period 1996-2005. All borrower characteristics are measured for the fiscal year prior to the agreement date.

\begin{tabular}{|c|c|c|c|c|c|c|}
\hline \multirow{2}{*}{$\begin{array}{l}\text { Panel A: Firm Characteristics } \\
\text { Total Assets (\$ Millions) }\end{array}$} & $\mathrm{N}$ & Mean & Std & $\mathrm{P} 25$ & Median & P75 \\
\hline & 3,720 & 3268.2 & 10157.1 & 208.4 & 675.9 & 2154.1 \\
\hline Market Value of Equity (\$ Millions) & 3,671 & 2918.8 & 9172.9 & 166.7 & 608.7 & 1955.2 \\
\hline Sales (\$ Millions) & 3,720 & 2609.5 & 6262.9 & 204.0 & 643.5 & 2126.5 \\
\hline Net Income (\$ Millions) & 3,720 & 48.6 & 1718.8 & 0.1 & 17.8 & 80.3 \\
\hline Loss Indicator & 3,720 & 0.2 & 0.4 & 0.0 & 0.0 & 0.0 \\
\hline Capital Expenditure (\$ Millions) & 3,720 & 177.7 & 584.5 & 8.6 & 34.1 & 122.9 \\
\hline Research and Development (\$ Millions) & 3,720 & 33.9 & 195.0 & 0.0 & 0.0 & 5.3 \\
\hline Investment (R\&D + Capex) (\$ Millions) & 3,720 & 211.6 & 656.3 & 11.5 & 42.5 & 154.4 \\
\hline Panel B: Loan Characteristics & $\mathrm{N}$ & Mean & Std & $\mathrm{P} 25$ & Median & P75 \\
\hline Deal Amount (\$ Millions) & 3,682 & 441.4 & 967.4 & 69.5 & 190.0 & 450.0 \\
\hline Maturity (month) & 3,682 & 43.8 & 20.4 & 33.0 & 42.0 & 60.0 \\
\hline Interest Spread (basis points above LIBOR) & 3,682 & 169.2 & 116.6 & 75.0 & 150.0 & 240.6 \\
\hline Line of Credit Indicator & 3,682 & 0.9 & 0.3 & 1.0 & 1.0 & 1.0 \\
\hline Secured Debt Indicator & 3,682 & 0.5 & 0.5 & 0.0 & 1.0 & 1.0 \\
\hline Number of Lenders & 3,682 & 8.2 & 8.3 & 2.0 & 6.0 & 12.0 \\
\hline Accounting-based Performance Pricing Indicator & 3,682 & 0.5 & 0.5 & 0.0 & 1.0 & 1.0 \\
\hline Accounting-based Borrowing Base Indicator & 3,682 & 0.2 & 0.4 & 0.0 & 0.0 & 0.0 \\
\hline Number of Financial Covenants & 3,720 & 2.6 & 1.3 & 2.0 & 3.0 & 3.0 \\
\hline & 3,720 & 1.0 & 0.2 & 1.0 & 1.0 & 1.0 \\
\hline Income-statement-based Covenant Indicator & 3,720 & 0.8 & 0.4 & 1.0 & 1.0 & 1.0 \\
\hline Balance-sheet-based Covenant Indicator & 3,720 & 0.7 & 0.5 & 0.0 & 1.0 & 1.0 \\
\hline \multicolumn{5}{|l|}{ Panel C: Deal Distribution by Initiation Years } & \multicolumn{2}{|c|}{ Freq. Percent } \\
\hline 1996 & & & & & 111 & 3.0 \\
\hline 1997 & & & & & 441 & 11.9 \\
\hline 1998 & & & & & 403 & 10.8 \\
\hline 1999 & & & & & 390 & 10.5 \\
\hline 2000 & & & & & 361 & 9.7 \\
\hline 2001 & & & & & 361 & 9.7 \\
\hline 2002 & & & & & 419 & 11.3 \\
\hline 2003 & & & & & 399 & 10.7 \\
\hline 2004 & & & & & 473 & 12.7 \\
\hline 2005 & & & & & 362 & 9.7 \\
\hline Panel D: Deal Distribution by Fama-French 12 & adustr & & & & Freq. & Percent \\
\hline Consumer Nondurables & & & & & 276 & 7.4 \\
\hline mer Durables & & & & & 108 & 2.9 \\
\hline Manufacturing & & & & & 593 & 15.9 \\
\hline Oil, Gas, and Coal Extraction and Products & & & & & 307 & 8.3 \\
\hline Chemicals and Allied Products & & & & & 125 & 3.4 \\
\hline Business Equipment & & & & & 454 & 12.2 \\
\hline Telephone and Television Transmission & & & & & 192 & 5.2 \\
\hline Utilities & & & & & 226 & 6.1 \\
\hline Wholesale, Retail, and Some Services & & & & & 533 & 14.3 \\
\hline Healthcare, Medical Equipment, and Drugs & & & & & 255 & 6.9 \\
\hline Other & & & & & 651 & 17.5 \\
\hline
\end{tabular}




\section{Table 2 Composition of Renegotiation Cases}

This table presents the percentages of renegotiations related to accounting-based terms. Major terms include principal, interest, maturity, and accounting-based contractual terms. Panel A breaks down the renegotiations by provision (i.e., covenants, performance pricing, and borrowing base). Panel B breaks down the renegotiations of financial covenants by type. Panel $\mathrm{C}$ breaks down the renegotiations of accounting-based contractual terms by action.

Event A: Any Major Terms Being Renegotiated

Event B: Any Accounting-based Terms Being Renegotiated

Event C: Existence of the Accounting-based Term in the Corresponding Row

Panel A: Renegotiations of Accounting-based Contractual Terms

Any Major Terms Renegotiated (Event A)

\begin{tabular}{cccc}
\multicolumn{5}{c}{ Full Sample $(\mathrm{N}=3,720)$} \\
\hline $\operatorname{Pr}()$. & $\operatorname{Pr}(. \mid A)$ & $\operatorname{Pr}(. \mid B) \operatorname{Pr}(. \mid C)$ \\
\hline 0.758 & 1 & & \\
0.566 & 0.747 & 1 & \\
0.513 & 0.678 & 0.907 & 0.529 \\
0.197 & 0.260 & 0.348 & 0.365 \\
0.059 & 0.078 & 0.104 & 0.301
\end{tabular}

Any Accounting-based Terms Renegotiated (Event B)

Accounting-based Covenant

y Type

Accounting-based Performance Pricing

Accounting-based Borrowing Base

\begin{tabular}{cccc}
$\operatorname{Pr}()$. & $\operatorname{Pr}(. \mid A)$ & $\operatorname{Pr}(. \mid B)$ & $\operatorname{Pr}(. \mid C)$ \\
\hline 0.281 & 0.370 & 0.495 & 0.446 \\
0.164 & 0.216 & 0.289 & 0.378 \\
0.151 & 0.199 & 0.267 & 0.331 \\
0.089 & 0.117 & 0.157 & 0.444 \\
0.055 & 0.072 & 0.097 & 0.419 \\
0.026 & 0.034 & 0.046 & 0.291 \\
0.013 & 0.017 & 0.023 & 0.228 \\
0.108 & 0.143 & 0.191 & 0.344 \\
0.071 & 0.093 & 0.125 & 0.329 \\
0.060 & 0.079 & 0.105 & 0.233 \\
0.020 & 0.027 & 0.035 & 0.211 \\
0.016 & 0.021 & 0.028 & 0.183 \\
0.014 & 0.018 & 0.024 & 0.133 \\
0.010 & 0.013 & 0.018 & 0.129 \\
0.006 & 0.009 & 0.011 & 0.225 \\
0.005 & 0.007 & 0.009 & 0.232 \\
0.004 & 0.005 & 0.007 & 0.250 \\
0.112 & 0.148 & 0.197 & 0.283
\end{tabular}

Other Covenants: Capital Expenditure

Debt to Cash Flow/Earnings

Fixed Charge Coverage

Interest Coverage

Cash Flow/Earnings

Senior Debt to Cash Flow/Earnings

Other Coverage

Debt Service Coverage

BS Covenants:
Net Worth

Tangible Net Worth

Debt to Capitalization

Debt to Net Worth

Other Liquidity

Current Ratio

Other BS Ratio

Quick Ratio

Working Capital

Shareholder's Equity

0.112

0.148

$0.197 \quad 0.283$

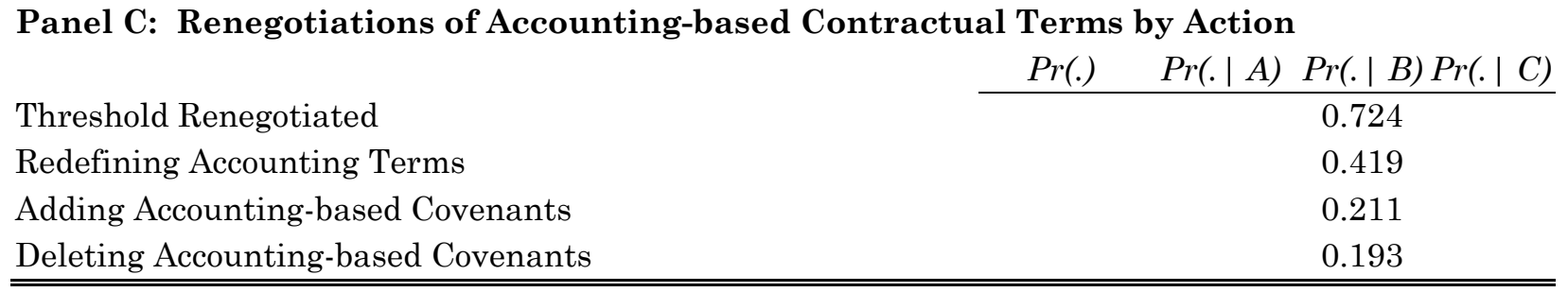




\section{Table 3 Estimation of Debt-Contracting Value of Accounting Numbers}

This table presents the distribution of coefficients in equation (1) using Compustat firms from 19902005. Specifically, for each year starting from 1995, equation (1) is estimated by Fama-French industry (48 categories) using the data from past five years. $E_{t-k}$ is EBITDA divided by total assets in quarter $t-k$. $C O V_{t-k}$ is interest coverage divided by total interest expense. $L E V_{t-k}$ is long-term debt divided by total assets in quarter. $N W_{t-k}$ is net worth divided by total assets. Each regression requires at least 100 firm-quarter observations. Fama-MacBeth $t$-statistics are presented in parentheses

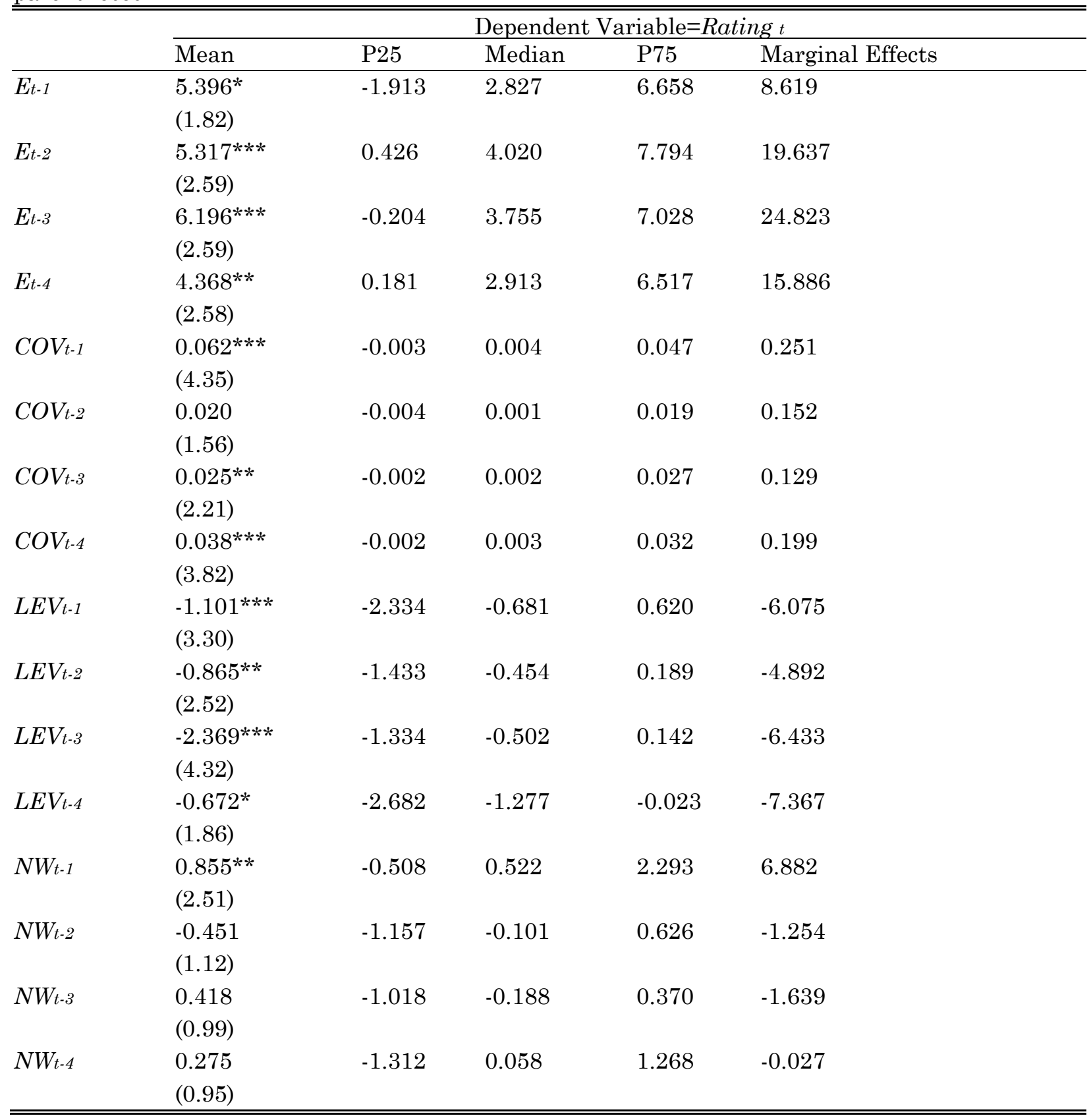


Table 4 Summary Statistics for Multivariate Analyses

This table presents summary statistics of variables used in the cross-sectional analyses. Variables are defined in Appendix IV.

\begin{tabular}{|c|c|c|c|c|c|c|c|c|}
\hline Variable & $\mathrm{N}$ & Mean & Std & $\mathrm{P} 10$ & $\mathrm{P} 25$ & Median & $\mathrm{P} 75$ & $\mathrm{P} 90$ \\
\hline \multicolumn{9}{|c|}{ Panel A: Dependent and Test Variables } \\
\hline$D C V$ & 3,625 & 0.572 & 0.068 & 0.488 & 0.506 & 0.562 & 0.650 & 0.665 \\
\hline RENEGDCV & 3,625 & 0.234 & 0.022 & 0.208 & 0.213 & 0.230 & 0.259 & 0.263 \\
\hline INVEST & 3,700 & 0.020 & 0.018 & 0.004 & 0.008 & 0.014 & 0.027 & 0.050 \\
\hline \multicolumn{9}{|c|}{ Panel B: Firm Characteristics } \\
\hline LNASSET & 3,720 & 6.574 & 1.732 & 4.402 & 5.357 & 6.510 & 7.679 & 8.926 \\
\hline DTE & 3,718 & 7.849 & 95.079 & 0.000 & 2.707 & 7.655 & 14.641 & 24.255 \\
\hline$L E V$ & 3,720 & 0.305 & 0.208 & 0.042 & 0.154 & 0.288 & 0.423 & 0.556 \\
\hline$R O A$ & 3,720 & 0.034 & 0.029 & 0.008 & 0.021 & 0.033 & 0.046 & 0.063 \\
\hline$M T B$ & 3,719 & 1.784 & 1.389 & 0.941 & 1.112 & 1.422 & 1.987 & 2.914 \\
\hline ZSCORE & 3,719 & 2.852 & 10.324 & 0.330 & 0.892 & 1.700 & 3.019 & 5.620 \\
\hline STDROA & 3,719 & 0.018 & 0.024 & 0.004 & 0.006 & 0.011 & 0.021 & 0.036 \\
\hline$Q$ & 3,671 & 1.778 & 1.580 & 0.919 & 1.095 & 1.411 & 1.968 & 2.915 \\
\hline$C F$ & 3,720 & 0.071 & 0.134 & -0.013 & 0.044 & 0.080 & 0.121 & 0.170 \\
\hline$R K$ & 3,576 & 0.114 & 0.246 & 0.000 & 0.006 & 0.029 & 0.127 & 0.328 \\
\hline KZIND & 3,671 & -21.271 & 4.975 & -27.574 & -26.491 & -21.349 & -16.116 & -14.913 \\
\hline$T A N G$ & 3,720 & 0.452 & 0.122 & 0.279 & 0.374 & 0.470 & 0.536 & 0.587 \\
\hline$L E A S E$ & 3,715 & 0.204 & 0.391 & 0.000 & 0.029 & 0.090 & 0.216 & 0.491 \\
\hline STDINVEST & 3,409 & 0.161 & 0.462 & 0.008 & 0.015 & 0.031 & 0.080 & 0.244 \\
\hline$A G E$ & 3,720 & 20.361 & 15.957 & 5.000 & 7.000 & 14.000 & 32.000 & 47.500 \\
\hline$S A L E G$ & 3,697 & 0.517 & 10.357 & -0.112 & 0.005 & 0.106 & 0.286 & 0.659 \\
\hline \multicolumn{9}{|c|}{ Panel C: Lender Characteristics } \\
\hline INSTLP & 3,564 & -0.049 & 0.053 & -0.101 & -0.067 & -0.039 & -0.017 & -0.001 \\
\hline FLENDER & 3,682 & -0.206 & 0.229 & -0.524 & -0.375 & -0.143 & 0.000 & 0.000 \\
\hline \multicolumn{9}{|c|}{ Panel D: Loan Characteristics } \\
\hline RELINT & 3,564 & 0.754 & 0.273 & 0.318 & 0.556 & 0.848 & 1.000 & 1.000 \\
\hline LNMATURITY & 3,682 & 3.628 & 0.621 & 2.485 & 3.497 & 3.738 & 4.094 & 4.174 \\
\hline$S P R E A D$ & 3,682 & 169.208 & 116.552 & 42.000 & 75.000 & 150.000 & 240.625 & 318.421 \\
\hline NLENDER & 3,682 & 8.211 & 8.309 & 1.000 & 2.000 & 6.000 & 12.000 & 18.000 \\
\hline$D A M O U N T$ & 3,682 & -1.435 & 1.000 & -2.722 & -2.057 & -1.367 & -0.741 & -0.245 \\
\hline$R E V L V$ & 3,682 & 0.710 & 0.375 & 0.000 & 0.426 & 1.000 & 1.000 & 1.000 \\
\hline$P G$ & 3,682 & 0.723 & 0.430 & 0.000 & 0.254 & 1.000 & 1.000 & 1.000 \\
\hline BOWBASE & 3,682 & 0.144 & 0.331 & 0.000 & 0.000 & 0.000 & 0.000 & 1.000 \\
\hline COVIS & 3,720 & 0.844 & 0.363 & 0.000 & 1.000 & 1.000 & 1.000 & 1.000 \\
\hline COVBS & 3,720 & 0.667 & 0.471 & 0.000 & 0.000 & 1.000 & 1.000 & 1.000 \\
\hline$C O L L$ & 3,682 & 0.538 & 0.496 & 0.000 & 0.000 & 1.000 & 1.000 & 1.000 \\
\hline \multicolumn{9}{|c|}{ Panel E: Governance Variables } \\
\hline INSTHOLD & 3,720 & 0.488 & 0.274 & 0.058 & 0.266 & 0.528 & 0.713 & 0.828 \\
\hline$A N A L Y F$ & 3,720 & 7.899 & 8.065 & 0.000 & 1.000 & 6.000 & 12.000 & 19.000 \\
\hline INVGS & 3,720 & -0.025 & 0.128 & -0.076 & -0.054 & -0.028 & 0.000 & 0.017 \\
\hline GSCORED & 3,720 & 0.065 & 0.247 & 0.000 & 0.000 & 0.000 & 0.000 & 0.000 \\
\hline CAPEXREST & 3,720 & 0.326 & 0.469 & 0.000 & 0.000 & 0.000 & 1.000 & 1.000 \\
\hline
\end{tabular}




\section{Table 5 Loan-Quarter Level Incidence of Renegotiation Analyses across Debt-Contracting Value of Accounting Numbers and Shocks}

This table presents the results of the interaction effect between $D C V$ and shocks on the probability of renegotiation. The sample consists of 19,282 loan-quarter observations. The first observation for each loan corresponds to the quarter of origination and the last observation corresponds to the ultimate outcome of the loan (mature, renegotiation, or stopping filings). RENEGQ is an indicator variable, which equals one if there is any renegotiation during that loan-quarter. Shocks are measured as the absolute value of changes in Hillegeist et al. (2004)'s default distance ( $D D$ ) in quarter $q+1$ for any particular quarter $q$ relative to the quarter prior to origination (quarter 1). Negative (positive) shocks mean negative (positive) changes in $D D$. I partition $D C V$ and shocks into values above and below the median.

Shock,$i=\mid D D_{q+1, i-D D_{1, i} \mid}$

Variable $=$ RENEGQ

Panel A:

Full Sample

\begin{tabular}{|c|c|c|c|c|}
\hline \multirow{3}{*}{ Low $D C V$} & \multirow{3}{*}{ Mean } & High Shock & Low Shock & Diff. \\
\hline & & 0.140 & 0.122 & $0.018^{\circ}$ \\
\hline & & $(\mathrm{N}=4909)$ & $(\mathrm{N}=4709)$ & $(t=2.562)$ \\
\hline \multirow[t]{3}{*}{ High $D C V$} & Mean & 0.121 & 0.118 & 0.003 \\
\hline & & $(\mathrm{N}=4849)$ & $(\mathrm{N}=4815)$ & $(\mathrm{t}=0.468)$ \\
\hline & Diff. & $\begin{array}{l}0.018 * * * \\
(t=2.710)\end{array}$ & $\begin{array}{r}0.004 \\
(\mathrm{t}=0.590)\end{array}$ & \\
\hline
\end{tabular}

Panel B:

Negative Shocks Sample

Low $D C V \quad$ Mean

\begin{tabular}{rr}
\hline High Shock & Low Shock \\
\hline 0.143 & 0.125
\end{tabular}

$(\mathrm{N}=2577)$

$(\mathrm{N}=2427)$

Diff.

$0.018 *$

$(\mathrm{t}=1.858)$

High $D C V \quad$ Mean

0.123

0.123

0.006

$(\mathrm{N}=2452)$

$(\mathrm{N}=2480)$

$(\mathrm{t}=0.669)$

Diff.

$0.020 * *$

0.003

$(\mathrm{t}=2.132)$

$(\mathrm{t}=0.284)$

Panel C:

Positive Shocks Sample

\begin{tabular}{|c|c|c|c|c|}
\hline \multirow{3}{*}{ Low $D C V$} & \multirow{3}{*}{ Mean } & High Shock & Low Shock & \multirow{3}{*}{$\begin{array}{r}\text { Diff. } \\
0.017 * \\
(\mathrm{t}=1.750)\end{array}$} \\
\hline & & 0.136 & 0.119 & \\
\hline & & $(\mathrm{N}=2332)$ & $(\mathrm{N}=2282)$ & \\
\hline \multirow[t]{2}{*}{ High $D C V$} & Mean & $\begin{array}{r}0.120 \\
(\mathrm{~N}=2397)\end{array}$ & $\begin{array}{r}0.113 \\
(\mathrm{~N}=2335)\end{array}$ & $\begin{array}{r}0.006 \\
(t=0.669)\end{array}$ \\
\hline & Diff. & $\begin{array}{r}0.016^{*} \\
(t=1.669)\end{array}$ & $\begin{array}{r}0.005 \\
(\mathrm{t}=0.558)\end{array}$ & \\
\hline
\end{tabular}




\section{Table 6 Ex Ante Determinants of Probability of Renegotiation}

This table presents estimation results of pooled Probit regressions for the full sample and the sample after deleting renegotiations not involving changes in accounting-based terms. The dependent variable in all regressions is an indicator variable (RENEG) that equals one if the contract is renegotiated before maturity. Deal purpose fixed effects correspond to four categories (general corporate purpose, recapitalization, acquisition, and others). Year fixed effects correspond to the loan initiation years. Credit rating fixed effects have six categories (A-rated or better, BAA-rated, BArated, B-rated, CAA-rated, and unrated firms). Variables are defined in Appendix IV, and continuous variables are winsorized at the 1st and 99th percentile. Clustered $z$-statistics by firm are presented in parentheses. * Significant at $0.10 ; * *$ Significant at $0.05 ; * *$ Significant at 0.01 (two-sided test).

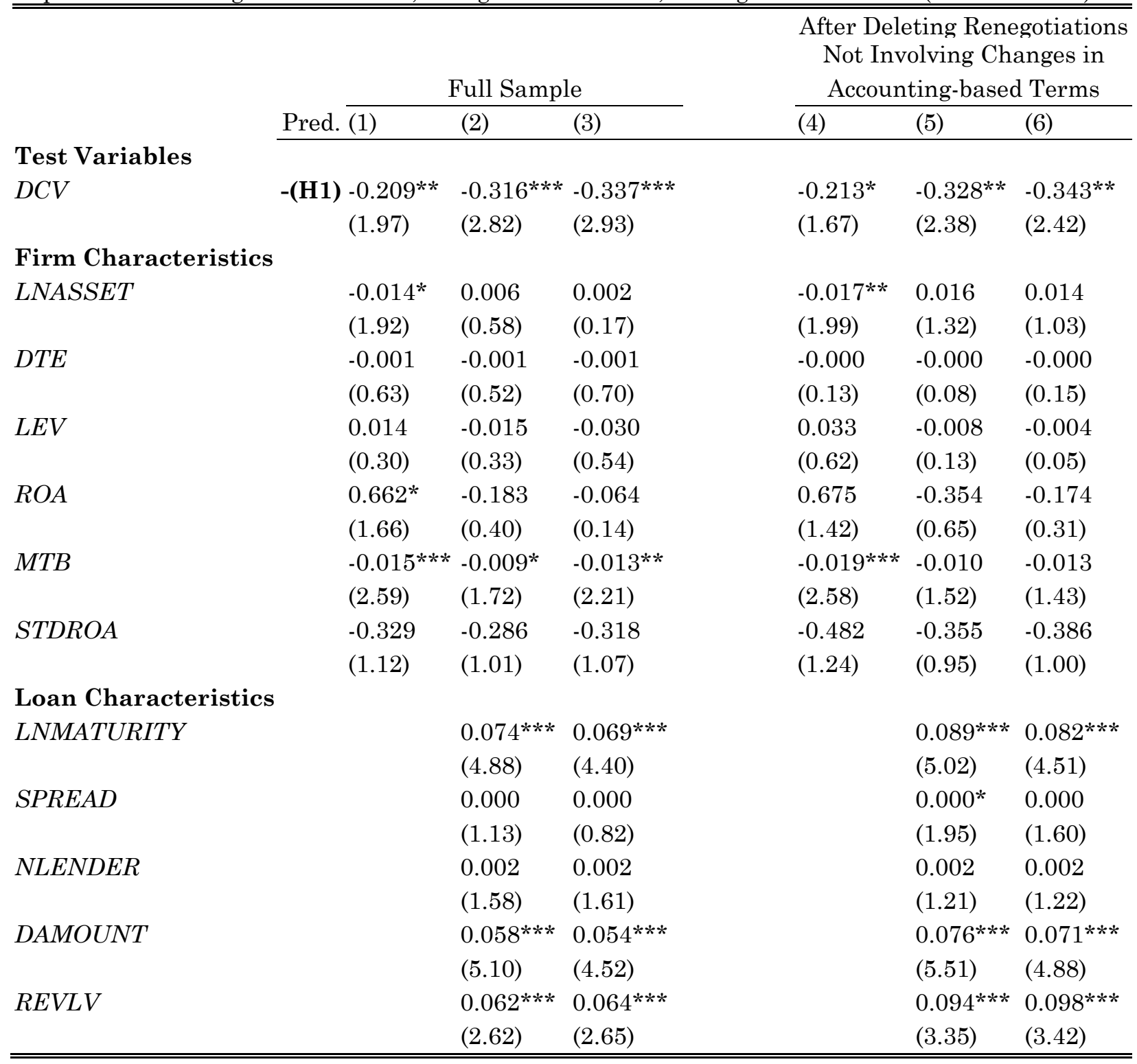

(Table 6 continued on next page) 


\section{Table 6 Ex Ante Determinants of Probability of Renegotiation ---continued}

After Deleting Renegotiations Not Involving Changes in

\begin{tabular}{|c|c|c|c|c|c|c|}
\hline & \multicolumn{3}{|c|}{ Full Sample } & \multicolumn{3}{|c|}{ Accounting-based Terms } \\
\hline & \multirow[t]{3}{*}{ Pred. (1) } & $(2)$ & (3) & (4) & (5) & (6) \\
\hline \multirow[t]{2}{*}{$P G$} & & $0.049 * * *$ & $0.057 * * *$ & & $0.067^{* * *}$ & $0.077 * * *$ \\
\hline & & $(2.61)$ & $(3.00)$ & & $(2.98)$ & $(3.33)$ \\
\hline \multirow[t]{2}{*}{$B O W B A S E$} & & 0.040 & $0.053^{*}$ & & $0.065^{* *}$ & $0.078^{* *}$ \\
\hline & & $(1.52)$ & $(1.88)$ & & $(2.06)$ & $(2.29)$ \\
\hline \multirow[t]{2}{*}{ COVIS } & & -0.006 & 0.001 & & $0.069 * *$ & $0.076^{* *}$ \\
\hline & & $(0.28)$ & $(0.06)$ & & $(2.36)$ & $(2.52)$ \\
\hline \multicolumn{7}{|c|}{ Additional Controls } \\
\hline \multirow[t]{2}{*}{ COVBS } & & & 0.004 & & & 0.024 \\
\hline & & & $(0.24)$ & & & $(1.14)$ \\
\hline \multirow[t]{2}{*}{ ZSCORE } & & & $0.001^{*}$ & & & 0.001 \\
\hline & & & $(1.65)$ & & & $(0.55)$ \\
\hline \multirow[t]{2}{*}{$T A N G$} & & & -0.093 & & & -0.119 \\
\hline & & & (1.33) & & & $(1.41)$ \\
\hline \multirow[t]{2}{*}{$K Z I N D$} & & & -0.002 & & & -0.001 \\
\hline & & & $(0.71)$ & & & $(0.33)$ \\
\hline \multirow[t]{2}{*}{$C O L L$} & & & 0.009 & & & 0.028 \\
\hline & & & $(0.43)$ & & & $(1.11)$ \\
\hline \multirow[t]{2}{*}{ RELINT } & & & 0.021 & & & 0.038 \\
\hline & & & $(0.70)$ & & & $(1.05)$ \\
\hline \multirow[t]{2}{*}{ INSTLP } & & & -0.253 & & & -0.302 \\
\hline & & & $(1.50)$ & & & $(1.41)$ \\
\hline \multirow[t]{2}{*}{ FLENDER } & & & 0.037 & & & 0.045 \\
\hline & & & $(0.93)$ & & & $(0.92)$ \\
\hline Deal Purpose FE & YES & YES & YES & YES & YES & YES \\
\hline Year FE & YES & YES & YES & YES & YES & YES \\
\hline Credit Rating FE & YES & YES & YES & YES & YES & YES \\
\hline Observations & 3585 & 3585 & 3431 & 2894 & 2894 & 2767 \\
\hline Log Likelihood & \multicolumn{3}{|c|}{$-1952.622-1873.619-1778.989$} & \multicolumn{3}{|c|}{$-1701.853-1607.646-1523.830$} \\
\hline
\end{tabular}




\section{Table 7 Underinvestment}

This table shows evidence of the underinvestment problem. The investment INVEST is the average of quarterly capital expenditures plus R\&D scaled by total assets starting from the quarter after signing the debt contract and ending with the quarter before renegotiation or before maturity in cases where there is no renegotiation. For each sample firm, I calculate INVEST in the same period as the sample firm for the other Compustat firms in the same year and 2-digit SIC industry. I then pool the sample firm with the Compustat firms together and regress INVEST on $Q$ and $C F$ to obtain the residuals as the abnormal investment. Panel A columns (1) and (2) present the mean and median of the abnormal investment for my sample firms. The remaining four columns of Panel A present the mean and median of my sample firms' investment, less matched firms' investment. I select the matched firms in two ways: (1) I use the same firm in the same period of the previous year; (2) I choose the firms in the same year and 2-digit SIC industry with the closest sales growth. Panel B deletes the sample firms with CAPEX covenants. Panel C presents the results of OLS regressions of average ROA over the next one, two or three years on INVEST controlling for other determinants. Industry fixed effects correspond to the Fama and French 12-industry classification. Year fixed effects correspond to the loan initiation years. Control variables are defined in Appendix IV, and continuous variables are winsorized at the 1st and 99th percentile. For mean tests, clustered $t$ statistics by firm are presented in parentheses. For median tests, $z$-statistics are presented in parentheses. * Significant at $0.10 ; * *$ Significant at $0.05 ; * * *$ Significant at 0.01 (two-sided test).

\section{Panel A: Full Sample}

Matched-Pair Difference of the Investment

\begin{tabular}{|c|c|c|}
\hline Abnormal Investment & $\begin{array}{c}\text { Same Firm Same Period } \\
\text { in Year t-1 }\end{array}$ & $\begin{array}{c}\text { Same Year-Industry with } \\
\text { Closest Sales Growth }\end{array}$ \\
\hline Median & Median & Median \\
\hline
\end{tabular}

(1) (2)

(3) (4) $\quad(4)$

(4) (5)

(6)

$\begin{array}{lcccccc}\text { Diff } & -0.00591^{* * *} & -0.00577^{* * *} & -0.00156^{* * *} & -0.00038^{* * *} & -0.00568^{* * *} & -0.00107^{* * *} \\ \text { Statistics } & (12.41) & (26.60) & (8.37) & (4.92) & (9.11) & (3.69) \\ \text { N } & 3503 & 3503 & 3696 & 3696 & 3672 & 3672\end{array}$

Panel B: Sample after Deleting Treatment Firms with CAPEX Covenants

Matched-Pair Difference of the Investment

\begin{tabular}{|c|c|c|c|c|c|c|}
\hline & \multicolumn{2}{|c|}{ Abnormal Investment } & \multicolumn{2}{|c|}{$\begin{array}{c}\text { Same Firm Same Period } \\
\text { in Year t- } 1\end{array}$} & \multicolumn{2}{|c|}{$\begin{array}{l}\text { Same Year-Industry with } \\
\text { Closest Sales Growth }\end{array}$} \\
\hline & $\begin{array}{l}\text { Mean } \\
(1)\end{array}$ & $\begin{array}{l}\text { Median } \\
\text { (2) }\end{array}$ & $\begin{array}{c}\text { Mean } \\
(3)\end{array}$ & $\begin{array}{c}\text { Median } \\
\text { (4) }\end{array}$ & $\begin{array}{c}\text { Mean } \\
(5)\end{array}$ & $\begin{array}{l}\text { Median } \\
\quad(6)\end{array}$ \\
\hline Diff & $-0.00512^{* * *}$ & $-0.00523^{* * *}$ & $-0.00106^{* * *}$ & $-0.00030 * * *$ & $-0.00437^{* * *}$ & $-0.00070^{*}$ \\
\hline Statistics & $(8.91)$ & $(18.27)$ & $(4.59)$ & $(3.36)$ & $(5.78)$ & $(1.88)$ \\
\hline $\mathrm{N}$ & 2383 & 2383 & 2490 & 2490 & 2479 & 2479 \\
\hline
\end{tabular}

(Table 7 continued on next page) 
Table 7 Underinvestment---continued

\begin{tabular}{llll}
\hline \hline Panel C: Impact on Future & Operating Performance & \\
& $(1)$ & $(2)$ & $(3)$ \\
INVEST & $R O A 1$ & $R O A 2$ & $R O A 3$ \\
\cline { 2 - 4 } & $0.457^{* * *}$ & $0.463^{* *}$ & $0.439^{* *}$ \\
$Q$ & $(3.25)$ & $(2.24)$ & $(2.13)$ \\
& -0.004 & -0.008 & -0.008 \\
CF & $(1.22)$ & $(1.16)$ & $(1.19)$ \\
& 0.014 & 0.041 & 0.023 \\
STDROA & $(0.41)$ & $(1.09)$ & $(0.66)$ \\
& 0.018 & -0.094 & $-0.508^{* * *}$ \\
LNASSET & $(0.13)$ & $(0.70)$ & $(2.58)$ \\
LAGROA & $0.004^{* * * *}$ & $0.002^{*}$ & $0.004^{* * *}$ \\
Constant & $(3.24)$ & $(1.73)$ & $(2.83)$ \\
Industry FE & $0.681^{* * *}$ & $0.608^{* * *}$ & $0.680^{* * *}$ \\
Year FE & $(5.50)$ & $(4.73)$ & $(6.37)$ \\
Observations & 0.005 & 0.019 & -0.002 \\
Adj. R-squared & $(0.28)$ & $(1.17)$ & $(0.10)$ \\
\hline \hline & YES & YES & YES \\
YES & YES & YES \\
& 2950 & 2705 & 2384 \\
& 0.404 & 0.440 & 0.453 \\
\hline
\end{tabular}




\section{Table 8 Impact of Debt-Contracting Value of Accounting Numbers on Investment}

This table presents estimation results of OLS regressions of INVEST on the perceived probability of renegotiation interacting with bargaining power variables. INVEST is the average of quarterly capital expenditures plus R\&D scaled by total assets starting from the quarter after signing the debt contract and ending with the quarter before renegotiation or before maturity in cases where there is no renegotiation. RENEGDCV is one minus the predicted value by plugging $D C V$ and the means of other independent variables using the coefficients from column (2) of Table 6. INSTLP is the fraction of Type B, Type C, or Type D loans in the portfolio of the lead lender in past five years, multiplied by -1. FLENDER is the proportion of the syndicated loan held by foreign (i.e., non-US) lenders, multiplied by -1 . KZIND is the financial constraint index from Kaplan and Zingales (1997). TANG is the liquidation value from Berger et al. (1996). Deal purpose fixed effects correspond to four categories (general corporate purpose, recapitalization, acquisition, and others). Year fixed effects correspond to the loan initiation years. Credit rating fixed effects have six categories (A-rated or better, BAA-rated, BA-rated, B-rated, CAA-rated, and unrated firms). Control variables are defined in Appendix IV, and continuous variables are winsorized at the 1st and 99th percentile. Clustered $t$ statistics by firm are presented in parentheses. * Significant at 0.10 ; ** Significant at 0.05 ; *** Significant at 0.01 (two-sided test).

\begin{tabular}{|c|c|c|c|c|c|c|c|}
\hline & \multirow[b]{3}{*}{ Pred. } & \multirow[b]{3}{*}{ (1) } & \multirow[b]{3}{*}{ (2) } & \multicolumn{4}{|c|}{$B A R G P O W=$} \\
\hline & & & & INSTLP & FLENDER & KZIND & TANG \\
\hline & & & & $(3)$ & $(4)$ & $(5)$ & (6) \\
\hline \multicolumn{8}{|l|}{ Test Variables } \\
\hline RENEGDCV & $+(\mathrm{H} 2 \mathrm{a})$ & $\begin{array}{l}0.040^{* *} \\
(2.44)\end{array}$ & $\begin{array}{l}0.029^{*} \\
(1.82)\end{array}$ & $\begin{array}{l}0.055^{* *} \\
(2.44)\end{array}$ & $\begin{array}{l}0.058^{* * *} \\
(2.72)\end{array}$ & $\begin{array}{l}0.142^{* *} \\
(1.97)\end{array}$ & $\begin{array}{l}-0.054 \\
(1.08)\end{array}$ \\
\hline $\begin{array}{l}\text { RENEGDCV } \\
\quad \times B A R G P O W\end{array}$ & $+(\mathrm{H} 2 \mathrm{~b})$ & & & $\begin{array}{l}0.530^{*} \\
(1.81)\end{array}$ & $\begin{array}{l}0.144^{* *} \\
(2.12)\end{array}$ & $\begin{array}{l}0.005^{*} \\
(1.73)\end{array}$ & $\begin{array}{l}0.261^{* *} \\
(2.12)\end{array}$ \\
\hline BARGPOW & & & & $\begin{array}{l}-0.123^{*} \\
(1.77)\end{array}$ & $\begin{array}{l}-0.044^{* * *} \\
(2.70)\end{array}$ & $\begin{array}{l}-0.001 \\
(1.30)\end{array}$ & $\begin{array}{l}-0.021 \\
(0.71)\end{array}$ \\
\hline \multicolumn{8}{|c|}{ Traditional Controls } \\
\hline$Q$ & & $\begin{array}{l}0.002^{* * *} \\
(3.38)\end{array}$ & $\begin{array}{l}0.002^{* *} \\
(2.55)\end{array}$ & $\begin{array}{l}0.002^{* *} \\
(2.32)\end{array}$ & $\begin{array}{l}0.002^{* *} \\
(2.55)\end{array}$ & $\begin{array}{l}0.002^{* * * *} \\
(2.94)\end{array}$ & $\begin{array}{l}0.002^{* * *} \\
(3.00)\end{array}$ \\
\hline$C F$ & & $\begin{array}{l}0.012^{* * *} \\
(2.70)\end{array}$ & $\begin{array}{l}0.014^{* * *} \\
(3.23)\end{array}$ & $\begin{array}{l}0.014^{* * *} \\
(3.06)\end{array}$ & $\begin{array}{l}0.013^{* * *} \\
(3.15)\end{array}$ & $\begin{array}{l}0.013^{* * *} \\
(3.17)\end{array}$ & $\begin{array}{l}0.013^{* * *} \\
(3.00)\end{array}$ \\
\hline \multicolumn{8}{|c|}{ Governance Variables } \\
\hline INSTHOLD & & & $\begin{array}{l}-0.002 \\
(0.96)\end{array}$ & $\begin{array}{l}-0.001 \\
(0.87)\end{array}$ & $\begin{array}{l}-0.002 \\
(1.01)\end{array}$ & $\begin{array}{l}-0.002 \\
(1.22)\end{array}$ & $\begin{array}{l}-0.001 \\
(0.87)\end{array}$ \\
\hline$A N A L Y F$ & & & $\begin{array}{l}0.001^{* * *} \\
(9.61)\end{array}$ & $\begin{array}{l}0.001^{* * * *} \\
(9.66)\end{array}$ & $\begin{array}{l}0.001^{* * *} \\
(9.43)\end{array}$ & $\begin{array}{l}0.001^{* * *} \\
(9.34)\end{array}$ & $\begin{array}{l}0.001^{* * * *} \\
(8.33)\end{array}$ \\
\hline INVGS & & & $\begin{array}{l}0.003^{* *} \\
(2.36)\end{array}$ & $\begin{array}{l}0.003^{* *} \\
(2.40)\end{array}$ & $\begin{array}{l}0.003^{* *} \\
(2.42)\end{array}$ & $\begin{array}{l}0.003^{* *} \\
(2.48)\end{array}$ & $\begin{array}{l}0.003^{* * *} \\
(3.35)\end{array}$ \\
\hline GSCORED & & & $\begin{array}{l}0.001 \\
(0.40)\end{array}$ & $\begin{array}{l}0.001 \\
(0.31)\end{array}$ & $\begin{array}{l}0.000 \\
(0.21)\end{array}$ & $\begin{array}{l}0.002 \\
(0.90)\end{array}$ & $\begin{array}{l}0.001 \\
(0.33)\end{array}$ \\
\hline CAPEXREST & & & $\begin{array}{l}-0.004^{* * *} \\
(5.07)\end{array}$ & $\begin{array}{l}-0.004^{* * *} \\
(4.78)\end{array}$ & $\begin{array}{l}-0.004^{* * *} \\
(5.08)\end{array}$ & $\begin{array}{l}-0.004^{* * *} \\
(4.92)\end{array}$ & $\begin{array}{l}-0.004^{* * *} \\
(4.87)\end{array}$ \\
\hline
\end{tabular}

(Table 8 continued on next page) 
Table 8 Impact of Debt-Contracting Value of Accounting Numbers on Investment---continued

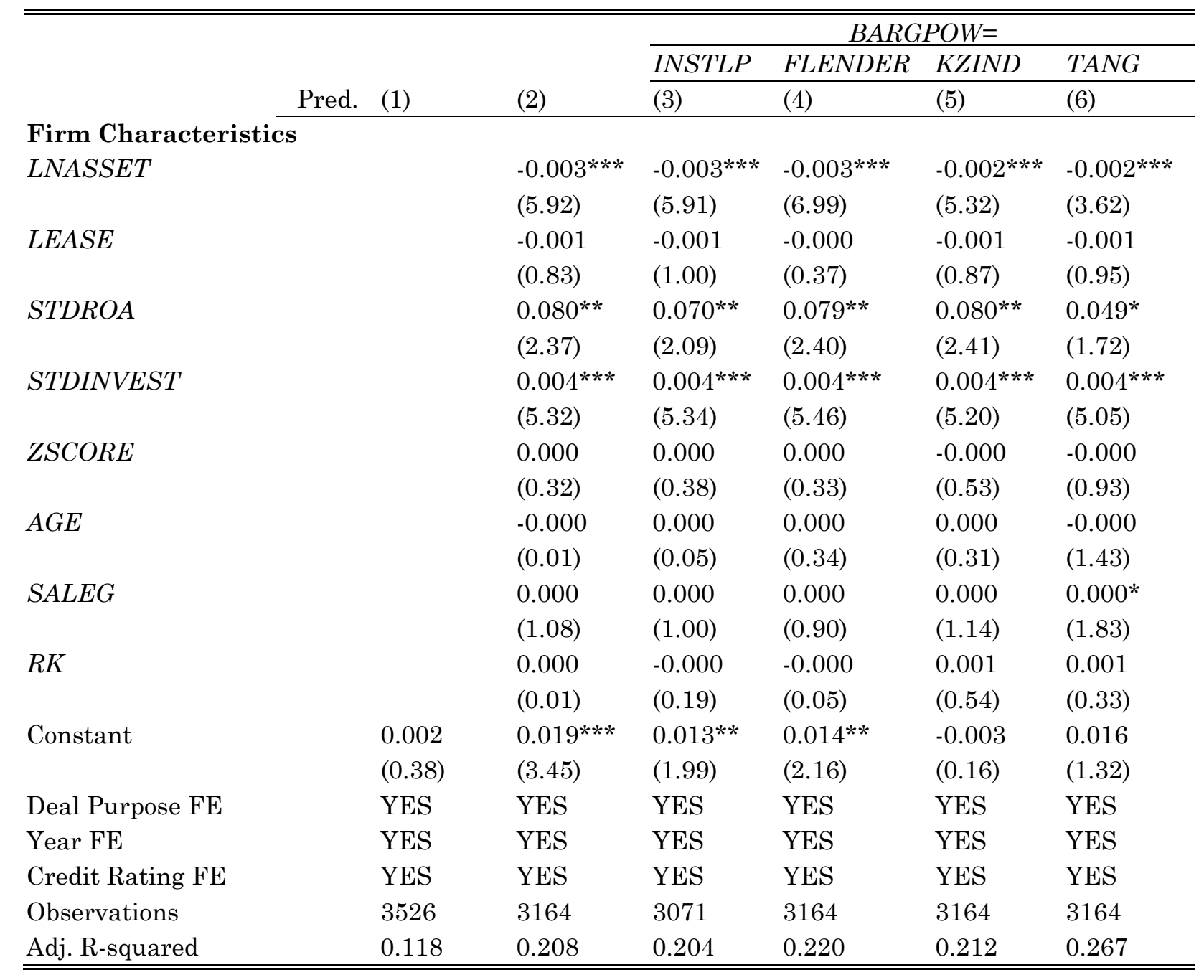




\section{Table 9 Alternative Debt-Contracting Value Measures}

This table presents estimation results of pooled Probit regressions for the full sample using alternative Debt-Contracting Value measures. The dependent variable in all regressions is an indicator variable (RENEG) that equals one if the contract is renegotiated before maturity. DCVO is the original debt-contracting value measure (Ball et al. 2008). $D C V F$ is a firm-specific debtcontracting value measure. $A Q$ is a measure of accounting quality (Francis et al. 2005). Firm characteristics, loan characteristics, and additional controls include the same variables as in Table 6 column (3). Deal purpose fixed effects correspond to four categories (general corporate purpose, recapitalization, acquisition, and others). Year fixed effects correspond to the loan initiation years. Credit rating fixed effects have six categories (A-rated or better, BAA-rated, BA-rated, B-rated, CAArated, and unrated firms). Industry fixed effects correspond to the Fama and French 12-industry classification. Variables are defined in Appendix IV, and continuous variables are winsorized at the 1st and 99th percentile. Clustered $z$-statistics by firm are presented in parentheses. * Significant at $0.10 ; * *$ Significant at $0.05 ; * * *$ Significant at 0.01 (two-sided test).

\begin{tabular}{lcc}
\multicolumn{3}{c}{ Dependent Variable $=R E N E G$} \\
\hline$(1)$ & $(2)$ & $(3)$
\end{tabular}

\section{Test Variables}

$D C V O$

$-0.330 * *$

$(2.52)$

$D C V F$

AQ

Firm Characteristics

Loan Characteristics

Additional Controls

Deal Purpose FE

Year FE

Credit Rating FE

Industry FE

Observations

Log Likelihood
$-0.026^{* * *}$

$\begin{array}{lll} & & -0.201^{*} \\ \text { YES } & & (1.76) \\ \text { YES } & \text { YES } & \text { YES } \\ \text { YES } & \text { YES } & \text { YES } \\ \text { YES } & \text { YES } & \text { YES } \\ \text { YES } & \text { YES } & \text { YES } \\ \text { YES } & \text { YES } & \text { YES } \\ \text { NO } & \text { YES } & \text { YES } \\ 3516 & 1723 & 3048 \\ -1811.617 & -857.004 & -1568.484\end{array}$




\section{Table 10 Additional Analyses on Renegotiation}

Column (1) presents a negative binomial regression of the Intensity of accounting-related renegotiation on $D C V$. Column (2) shows the result of Probit estimation in a sample with debt to earnings covenants where earnings used in debt to earnings covenants are equivalent to EBITDA. The dependent variable is an indicator variable that equals one if the debt-to-earnings covenant is renegotiated. Column (3) presents the estimation using $S R D$ as an instrument variable, and in column (4) the predicted $D C V$ from column (3) is used as an explanatory variable. $S R D$ is supplier industries R\&D using U.S. input-output table (Raman and Shahrur 2008). Column (5) presents the result of a survival analysis of how $D C V$ affects hazard ratio of renegotiation for each day. Deal purpose fixed effects correspond to four categories (general corporate purpose, recapitalization, acquisition, and others). Year fixed effects correspond to the loan initiation years. Credit rating fixed effects have six categories (A-rated or better, BAA-rated, BA-rated, B-rated, CAA-rated, and unrated firms). Control variables are defined in Appendix IV, and continuous variables are winsorized at the $1^{\text {st }}$ and $99^{\text {th }}$ percentile. * Significant at $0.10 ; * *$ Significant at $0.05 ; * * *$ Significant at 0.01 (two-sided test).

\begin{tabular}{|c|c|c|c|c|c|}
\hline \multirow{2}{*}{\multicolumn{2}{|c|}{$\begin{array}{c}\text { Number of Accounting } \\
\text { Related Changes } \\
\text { (1) } \\
\end{array}$}} & \multirow{3}{*}{$\begin{array}{l}\text { Deb-to-earnings } \\
\text { Renegotiation } \\
(2) \\
\end{array}$} & \multicolumn{2}{|c|}{ IV Approach } & \multirow[b]{2}{*}{$\begin{array}{c}\text { Hazard Ratio } \\
\text { (5) }\end{array}$} \\
\hline & & & $\begin{array}{c}D C V \\
(3)\end{array}$ & $\begin{array}{c}\text { RENEG } \\
\text { (4) }\end{array}$ & \\
\hline \multicolumn{5}{|c|}{ Test Variables } & \\
\hline$D C V$ & $\begin{array}{c}-0.590 * * \\
(2.54)\end{array}$ & $\begin{array}{c}-0.437 * * \\
(2.34)\end{array}$ & & $\begin{array}{c}-0.367 * * * \\
(2.80)\end{array}$ & $\begin{array}{c}-1.115^{* * *} \\
(3.65)\end{array}$ \\
\hline \multicolumn{6}{|c|}{ Firm Characteristics } \\
\hline LNASSET & $\begin{array}{c}0.054^{*} \\
(1.79)\end{array}$ & $\begin{array}{c}0.035^{*} \\
(1.69)\end{array}$ & $\begin{array}{l}0.001 \\
(0.88)\end{array}$ & $\begin{array}{l}0.004 \\
(0.12)\end{array}$ & $\begin{array}{l}0.046 \\
(1.52)\end{array}$ \\
\hline$D T E$ & $\begin{array}{l}0.004^{*} \\
(1.77)\end{array}$ & $\begin{array}{l}-0.001 \\
(0.42)\end{array}$ & $\begin{array}{l}-0.000 \\
(0.91)\end{array}$ & $\begin{array}{l}-0.003 \\
(0.95)\end{array}$ & $\begin{array}{l}-0.002 \\
(0.70)\end{array}$ \\
\hline$L E V$ & $\begin{array}{l}-0.009 \\
(0.06)\end{array}$ & $\begin{array}{l}0.163 \\
(1.38)\end{array}$ & $\begin{array}{c}0.038^{* * *} \\
(4.44)\end{array}$ & $\begin{array}{l}-0.029 \\
(0.16)\end{array}$ & $\begin{array}{l}0.136 \\
(0.76)\end{array}$ \\
\hline$R O A$ & $\begin{array}{l}-1.793 \\
(1.47)\end{array}$ & $\begin{array}{l}0.038 \\
(0.04)\end{array}$ & $\begin{array}{l}0.098 \\
(1.44)\end{array}$ & $\begin{array}{l}-0.052 \\
(0.03)\end{array}$ & $\begin{array}{l}-2.156 \\
(1.60)\end{array}$ \\
\hline$M T B$ & $\begin{array}{l}-0.004 \\
(0.20)\end{array}$ & $\begin{array}{l}-0.022 \\
(1.34)\end{array}$ & $\begin{array}{l}0.000 \\
(0.27)\end{array}$ & $\begin{array}{l}-0.035 \\
(1.61)\end{array}$ & $\begin{array}{l}-0.030 \\
(1.53)\end{array}$ \\
\hline STDROA & $\begin{array}{l}-0.997 \\
(1.03)\end{array}$ & $\begin{array}{l}-0.712 \\
(1.02)\end{array}$ & $\begin{array}{l}-0.011 \\
(0.23)\end{array}$ & $\begin{array}{l}-1.158 \\
(1.11)\end{array}$ & $\begin{array}{l}-0.716 \\
(0.65)\end{array}$ \\
\hline Loan Characte & eristics & & & & \\
\hline LNMATURITY & $\begin{array}{c}0.084^{*} \\
(1.74)\end{array}$ & $\begin{array}{c}0.080 * * \\
(2.56)\end{array}$ & $\begin{array}{c}0.007 * * * \\
(3.08)\end{array}$ & $\begin{array}{c}0.243^{* * *} \\
(5.03)\end{array}$ & $\begin{array}{c}-0.251^{* * *} \\
(5.50)\end{array}$ \\
\hline$S P R E A D$ & $\begin{array}{c}0.001^{* *} \\
(2.16)\end{array}$ & $\begin{array}{l}0.000 \\
(1.16)\end{array}$ & $\begin{array}{c}-0.000 \\
(0.19)\end{array}$ & $\begin{array}{l}0.000 \\
(0.75)\end{array}$ & $\begin{array}{c}0.001^{* *} \\
(2.42)\end{array}$ \\
\hline NLENDER & $\begin{array}{c}-0.001 \\
(0.28)\end{array}$ & $\begin{array}{l}0.001 \\
(0.50)\end{array}$ & $\begin{array}{l}0.000 \\
(0.04)\end{array}$ & $\begin{array}{c}0.008^{*} \\
(1.74)\end{array}$ & $\begin{array}{l}0.001 \\
(0.18)\end{array}$ \\
\hline$D A M O U N T$ & $\begin{array}{c}0.138 * * * \\
(3.76)\end{array}$ & $\begin{array}{c}0.068^{* * *} \\
(2.89)\end{array}$ & $\begin{array}{c}0.005^{* *} \\
(2.53)\end{array}$ & $\begin{array}{c}0.183^{* * *} \\
(4.74)\end{array}$ & $\begin{array}{c}0.204^{* * *} \\
(5.80)\end{array}$ \\
\hline$R E V L V$ & $\begin{array}{c}0.212^{* * *} \\
(2.94)\end{array}$ & $\begin{array}{l}0.055 \\
(1.28) \\
\end{array}$ & $\begin{array}{l}-0.005 \\
(1.50)\end{array}$ & $\begin{array}{c}0.190 * * \\
(2.49)\end{array}$ & $\begin{array}{l}0.058 \\
(0.85) \\
\end{array}$ \\
\hline
\end{tabular}

(Table 10 continued on next page) 
Table 10 Additional Analyses on Renegotiation--continued

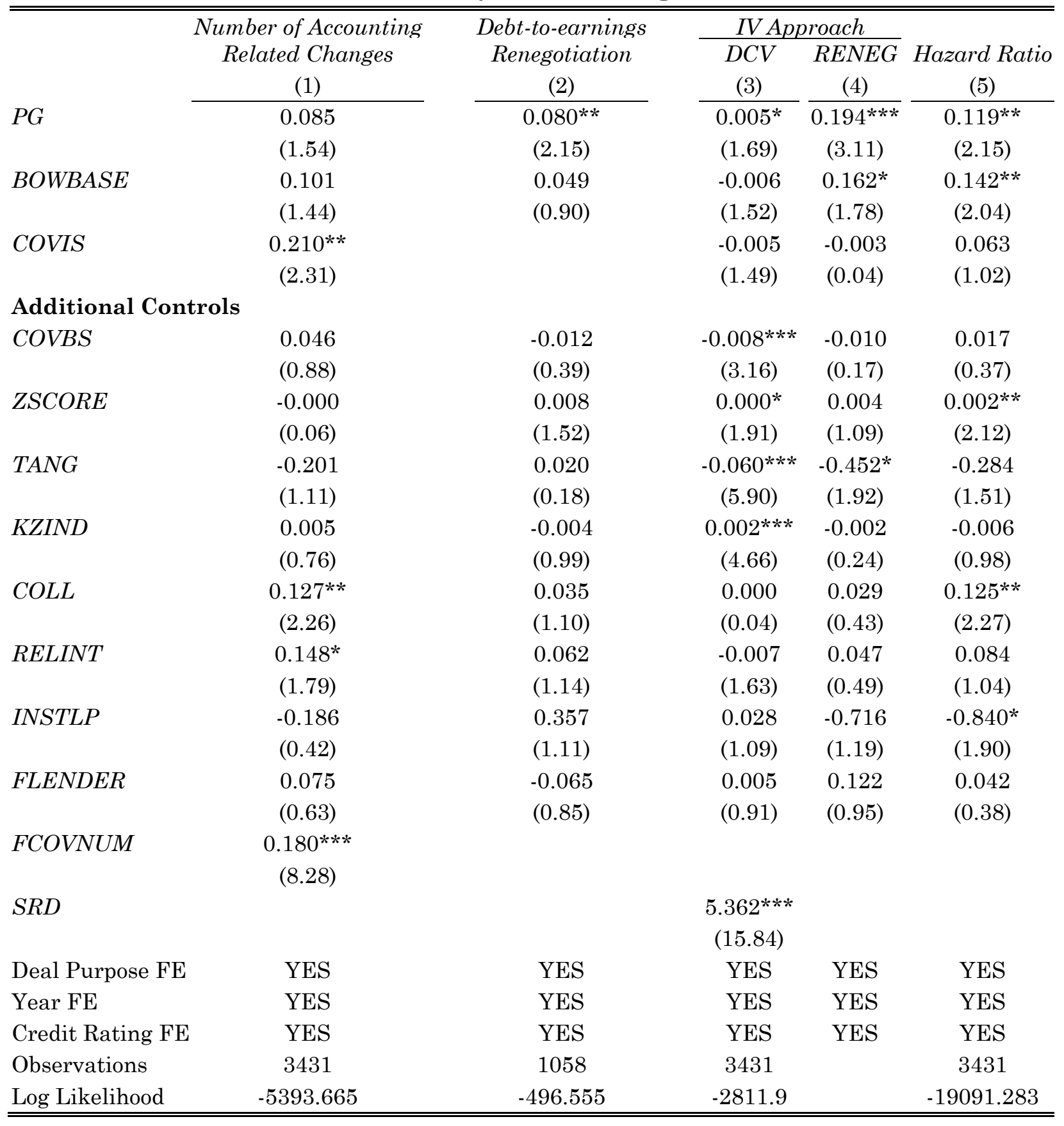




\section{Table 11 Management Forecasts and Conference Calls around Debt Contract Initiation}

This table presents the results testing whether borrowers disclose more after debt contract initiation. The period between loan initiation and renegotiation is the treatment window. A separate period with the same length as the treatment window preceding the initiation date is used as a control window. The dependent variables are the difference of disclosures between these two windows. $\Delta$ indicates the difference. $M F$ takes the value of 1 if any management forecast is issued and 0 otherwise. LOGNMFS is the log of one plus the number of forecasts issued. LOGNGMF (LOGNBMF) is the log of one plus the number of forecasts with positive abnormal returns in the three days window. LOGMFS is the quality of management guidance based on the Francis et al. (2008) management forecast score. $C C$ takes the value of 1 if any conference call occurs and 0 otherwise. LOGNCONFC is the log of one plus the number of conference calls. POST is the intercept which is equal to 1. $L E V$ is the leverage ratio. $M T B$ is the market-to-book ratio. $R O A$ is the return on assets. $R E T$ is the cumulative stock return between loan origination and renegotiation for each deal. CASPREAD is the yield on BB-rated bonds minus the yield on AAA-rated bonds. VWRET represents the return on CRSP value-weighted index. Firm characteristics, loan characteristics, and additional controls include the same variables as in Table 6 column (3). All the continuous variables are winsorized at the 1st and 99th percentile. Clustered $t$-statistics by firm are presented in parentheses. * Significant at $0.10 ; * *$ Significant at $0.05 ; * * *$ Significant at 0.01 (two-sided test).

\begin{tabular}{|c|c|c|c|c|c|c|c|}
\hline & $\begin{array}{l}(1) \\
\Delta M F\end{array}$ & $\begin{array}{l}(2) \\
\Delta L O G N M F\end{array}$ & $\begin{array}{l}(3) \\
\Delta L O G N G M F\end{array}$ & $\begin{array}{l}(4) \\
\triangle L O G N B M F\end{array}$ & $\begin{array}{l}(5) \\
\Delta L O G M F S\end{array}$ & $\begin{array}{l}(6) \\
\Delta C C\end{array}$ & $\begin{array}{l}(7) \\
\triangle L O G N C O N F C\end{array}$ \\
\hline POST & $\begin{array}{l}0.213^{* *} \\
(2.23)\end{array}$ & $\begin{array}{l}0.223^{*} \\
(1.73)\end{array}$ & $\begin{array}{l}0.267^{* *} \\
(2.48)\end{array}$ & $\begin{array}{l}-0.093 \\
(0.76)\end{array}$ & $\begin{array}{l}0.385^{* *} \\
(2.15)\end{array}$ & $\begin{array}{l}0.166^{* * *} \\
(2.79)\end{array}$ & $\begin{array}{l}0.297 * * * \\
(3.46)\end{array}$ \\
\hline$\triangle L E V$ & $\begin{array}{l}0.044 \\
(0.64)\end{array}$ & $\begin{array}{l}-0.066 \\
(0.67)\end{array}$ & $\begin{array}{l}-0.156^{* *} \\
(2.01)\end{array}$ & $\begin{array}{l}0.025 \\
(0.26)\end{array}$ & $\begin{array}{l}-0.045 \\
(0.33)\end{array}$ & $\begin{array}{l}0.067 \\
(1.46)\end{array}$ & $\begin{array}{l}0.017 \\
(0.26)\end{array}$ \\
\hline$\triangle M T B$ & $\begin{array}{l}-0.029^{* *} \\
(2.16)\end{array}$ & $\begin{array}{l}-0.065^{* * *} \\
(3.48)\end{array}$ & $\begin{array}{l}-0.027^{* *} \\
(2.01)\end{array}$ & $\begin{array}{l}-0.072^{* * *} \\
(3.56)\end{array}$ & $\begin{array}{l}-0.085^{* * *} \\
(3.26)\end{array}$ & $\begin{array}{l}0.019 \\
(1.48)\end{array}$ & $\begin{array}{l}0.011 \\
(0.52)\end{array}$ \\
\hline$\triangle R O A$ & $\begin{array}{l}-0.547^{* *} \\
(2.47)\end{array}$ & $\begin{array}{l}-0.242 \\
(0.93)\end{array}$ & $\begin{array}{l}0.368^{*} \\
(1.74)\end{array}$ & $\begin{array}{l}-0.535^{*} \\
(1.94)\end{array}$ & $\begin{array}{l}-0.468 \\
(1.26)\end{array}$ & $\begin{array}{l}0.021 \\
(0.16)\end{array}$ & $\begin{array}{l}-0.131 \\
(0.75)\end{array}$ \\
\hline$R E T$ & $\begin{array}{l}0.014 \\
(0.82)\end{array}$ & $\begin{array}{l}0.048^{* *} \\
(2.03)\end{array}$ & $\begin{array}{l}0.103^{* * *} \\
(4.92)\end{array}$ & $\begin{array}{l}-0.003 \\
(0.12)\end{array}$ & $\begin{array}{l}0.075^{* *} \\
(2.32)\end{array}$ & $\begin{array}{l}0.016 \\
(1.23)\end{array}$ & $\begin{array}{l}0.077^{* * *} \\
(4.26)\end{array}$ \\
\hline$\triangle C D S P R E A D$ & $\begin{array}{l}-0.026 \\
(1.10)\end{array}$ & $\begin{array}{l}-0.080^{*} \\
(1.88)\end{array}$ & $\begin{array}{l}0.026 \\
(0.64)\end{array}$ & $\begin{array}{l}-0.111^{* * *} \\
(2.76)\end{array}$ & $\begin{array}{l}-0.088 \\
(1.54)\end{array}$ & $\begin{array}{l}0.001 \\
(0.07)\end{array}$ & $\begin{array}{l}-0.015 \\
(0.52)\end{array}$ \\
\hline$V W R E T$ & $\begin{array}{l}-0.044 \\
(0.91)\end{array}$ & $\begin{array}{l}-0.268^{* * *} \\
(3.69)\end{array}$ & $\begin{array}{l}-0.211^{* * *} \\
(3.27)\end{array}$ & $\begin{array}{l}-0.206^{* * *} \\
(2.93)\end{array}$ & $\begin{array}{l}-0.342^{* * * *} \\
(3.42)\end{array}$ & $\begin{array}{l}-0.134^{* * *} \\
(3.54)\end{array}$ & $\begin{array}{l}-0.389^{* * *} \\
(7.91)\end{array}$ \\
\hline Firm Characteristics & YES & YES & YES & YES & YES & YES & YES \\
\hline Deal Characteristics & YES & YES & YES & YES & YES & YES & YES \\
\hline Observations & 2560 & 2560 & 2560 & 2560 & 2560 & 2560 & 2560 \\
\hline Adj. R-squared & 0.021 & 0.027 & 0.017 & 0.031 & 0.025 & 0.011 & 0.045 \\
\hline
\end{tabular}




\section{Table 12 Impact of Management Forecasts and Conference Calls on Renegotiation Outcomes}

This table presents the results testing whether more disclosures can increase the chance of favorable renegotiation outcomes for borrowers. The dependent variable is an indicator equal to 1 for loan amendments with at least one favorable loan contract term change, but with no unfavorable loan contract term changes, entailing smaller principal, a higher interest rate, or a shorter maturity. The period between loan initiation and renegotiation is the treatment window. A separate period with the same length as the treatment window preceding the initiation date is used as a control window. The test variables are the difference of disclosures between these two windows. $\Delta$ indicates the difference. $M F$ takes the value of 1 if any management forecast is issued and 0 otherwise. LOGNMFS is the log of one plus the number of forecasts issued. LOGNGMF ( $L O G N B M F)$ is the log of one plus the number of forecasts with positive (negative) abnormal returns in the three days window. LOGMFS is the quality of management guidance based on the Francis et al. (2008) management forecast score. CC takes the value of 1 if any conference call occurs and 0 otherwise. LOGNCONFC is the log of one plus the number of conference calls. $L E V$ is the leverage ratio. $M T B$ is the market-to-book ratio. $R O A$ is the return on assets. $R E T$ is the cumulative stock return between loan origination and renegotiation for each deal. CASPREAD is the yield on BB-rated bonds minus the yield on AAA-rated bonds. VWRET represents the return on CRSP value-weighted index. Firm characteristics, loan characteristics, and additional controls include the same variables as in Table 6 column (3). Deal purpose fixed effects correspond to four categories (general corporate purpose, recapitalization, acquisition, and others). Year fixed effects correspond to the loan initiation years. Industry fixed effects correspond to the Fama and French 12-industry classification. All the continuous variables are winsorized at the 1st and 99th percentile. Clustered $t$-statistics by firm are presented in parentheses. * Significant at $0.10 ; * *$ Significant at $0.05 ; * * *$ Significant at 0.01 (two-sided test).

\begin{tabular}{|c|c|c|c|c|c|c|c|}
\hline \multirow[b]{3}{*}{$\Delta M F$} & \multicolumn{7}{|c|}{ Dependent Variable=Renegotiation Outcomes } \\
\hline & $(1)$ & $(2)$ & (3) & (4) & (5) & (6) & $(7)$ \\
\hline & $\begin{array}{l}-0.022 \\
(1.01)\end{array}$ & & & & & & \\
\hline$\triangle L O G N M F$ & & $\begin{array}{l}0.008 \\
(0.50)\end{array}$ & & & & & \\
\hline$\triangle L O G N G M F$ & & & $\begin{array}{l}0.032^{*} \\
(1.74)\end{array}$ & & & & \\
\hline$\triangle L O G N B M F$ & & & & & & & \\
\hline$\triangle L O G M F S$ & & & & & & & \\
\hline$\Delta C C$ & & & & & & & \\
\hline$\triangle L O G N C O N F C$ & & & & & & & $\begin{array}{l}-0.034 \\
(1.35)\end{array}$ \\
\hline
\end{tabular}

(Table 12 continued on next page) 
Table 12 Impact of Management Forecasts and Conference Calls on Renegotiation Outcomes ---continued

$\triangle L E V$

Dependent Variable=Renegotiation Outcomes

$\triangle M T B$

\begin{tabular}{ccccccc}
$(1)$ & $(2)$ & $(3)$ & $(4)$ & $(5)$ & $(6)$ & $(7)$ \\
\hline-0.042 & -0.040 & -0.035 & -0.041 & -0.041 & -0.041 & -0.043
\end{tabular}

$\begin{array}{lllllll}(0.46) & (0.44) & (0.39) & (0.46) & (0.45) & (0.46) & (0.48)\end{array}$

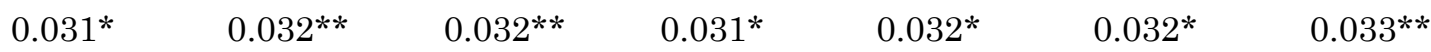

$\begin{array}{llllll}(1.91) & (1.97) & (1.98) & (1.92) & (1.96)\end{array}$

$\triangle R O A$

$$
0.439
$$

$0.426 \quad 0.434$

0.438

0.438

0.435

(1.47)

$(1.50)$

(1.46)

(1.49)

(1.50)

(1.50)

(1.49)

$R E T$

$\triangle C D S P R E A D$

$(2.52)$

(2.49)

$0.050^{* *}$

$0.053^{* *}$

$0.053^{* *}$

$0.053^{* *}$

$0.054^{* *}$

$-0.166^{* * *}$

(2.36)

(2.50)

(2.50)

(2.50)

(2.56)

(3.89)

$-0.164^{* * *}$

$-0.166^{* * *}$

$-0.166^{* * *}$

$-0.164^{* * *}$

$-0.165^{* * *}$

$-0.163^{* * *}$

\section{VWRET}

Firm Characteristics

0.097

0.098

0.102

(3.87)

(3.84)

(3.86)

(3.86)

(1.43)

(1.45)

(1.50)

YES

YES

0.096

0.098

0.098

0.094

YES

YES

(1.42)

(1.44)

(1.44)

(1.39)

Deal Characteristics

YES

Year FE

Industry FE

Observations

YES

YES

YES

YES

YES

YES

YES

YES YES

YES

YES

YES

YES

YES

YES

YES

YES

YES

YES

YES

YES

YES

2560

2560

YES

YES

YES

YES

YES

$-1451.016 \quad-1451.383$

$-1449.939$

$-1451.403$

2560

2560

YES

$-1451.482 \quad-1451.481$

2560

Log Likelihood 